BOTANICAL NAMES

FOR

ENGLISH READERS 




\section{BOTANICAL NAMES FOR}

\section{ENGLISH READERS.}


LONDON :

E. NEWMAN, PRINTER, 32, BOTOLPH LANE, EASTCHEAP, E.C. 


\title{
BOTANICAL NAMES
}

FOR

\section{ENGLISH READERS.}

\author{
BY \\ RANDAL H; ALCOCK.
}

"There may be a difference of opinion as to the advantage of spending much time upon the stady of Botany; but there is one opinion only as to the importance of knowing the names of the plants of which man has to make use, or which he is continually moeting with." - LINDLEY.

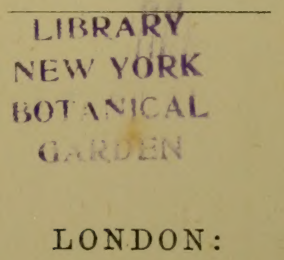

L. REEVE \& CO., 5, HENRIETTA STREET, COVENT GARDEN. 



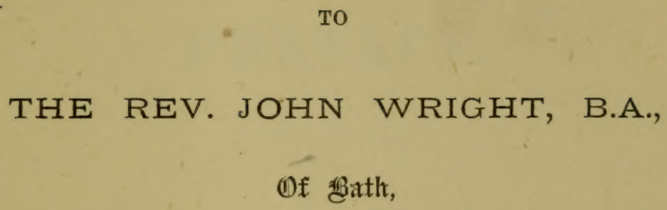

AS A SMALL TOKEN OF PERSONAL ESTEEM, AND OF

ADMIRATION FOR HIS PRACTICAL ENCOURAGEMENT OF RATIONAL THOUGHT AND EXTENDED EDUCATION

AMONG ALL CLASSES DURING A NUMBER OF YEARS, AND AS TO A DEAR FRIEND,

This Dolume is 코일ated by R. H. ALCOCK. 



\section{PREFACE.}

IT is a common complaint among those who wish to know something of Botany that they can make no progress because the scientific names of plants are so hard to learn, and it has occurred to me that something might be done to lessen the difficulty. It is much easier to remember names when they convey some meaning than when they are not understood, and the more information they convey the less liable are they to be forgotten. I have attempted in the following pages to explain the scientific names of British plants in a popular manner, so as to be useful to those who have no knowledge of any foreign language. I have also attached, so far as I could, the oldest authority for each name, in order to give an idea of its history; and, as this required some account of the authorities themselves, I have divided the work into two parts, the first of which is an 
account of most of the namers of plants up to the time of Linneus, so arranged as to give, at the same time, a general sketch of the History of Botany in that period; the second part deals with the meanings of the names only.

It gives me great pleasure to acknowledge my obligation, and express my best thanks, to the Rev. John Wright, of Bath, and to Mr. James Britten, of the British Museum, for their assistance in giving me many valuable suggestions and references, and much general information.

Hudcar House, Bury, Lancashire.

January 31st, 1876. 


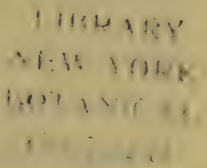

\section{INTRODUCTION.}

IT is impossible to gain any but a very superficial knowledge of Botany without learning the scientific names of plants. Even such a small section of the Vegetable Kingdom-less than a fiftieth part of the whole-as are inhabitants of Britain could not be distinguished by any English names that they have. There are, indeed, very few really old English names, for, as we shall see, Botany has only been studied in this country for about three hundred years, and the study commenced by importing both information and names from abroad. This may probably be accounted for by the comparatively small variety of our native plants, and their little use as human food. In the Bible we read of olives, datess, oil, wine, and numerous other vegetable productions; but our native edible fruits are fer, and could never be of much service in the way of supplying the people with food. Our natural sustenance would seem to be chiefly milk and the flesh of cattle for the inhabitants of the interior, and fish, shell-fish, and sea-weed in the maritime parts. Notwithstanding the great changes that have taken place during the last two thousand years, roast beef is 
still considered our national dish, and our cheese is celebrated, but oysters are not so abundant as they used to be.

Many names that we consider English are simply Latin or Greek,-as Angelica, Crocus, Asparagus; sometimes the terminations are slightly altered,-as in Agrimony (Agrimonia), Saxifrage (Saxifraga), Gentian (Gentiana); others are translations of continental names,-as Devil's-bit (Morsus diaboli), Hound's-tongue (Cynoglossum), Loose-strife (Lysimachia). We might suppose, however, when we meet with a name like "Jack of the Buttery" (Sedum acre), that such a one, at any rate, is English; but this is not always the case, for Dr. Prior, who is our best authority on these matters, tells us of this absurd appellation in his 'Popular Names of British Plants,' that it "seems to be a corruption of Bottheriacque to Buttery Jack, the plant having been used as a theriac or anthelmintic."

The popular names of our plants are well worth study, and are of great interest; but they are more for the student of philology than for the systematic botanist, as they are of little use to the latter.

Mr. Bentham ('Handbook of the British Flora') has invented a number of names, by prefixing an English specific name to the Latin or Greek generic one, altering the termination of the latter where necessary, in accordance with our usual practice, so as to gire the appearance of a systematic arrangement in our oтru language. He gives us such names 
as Common Sisymbrium, Cabbage Brassica, Common Cerast (Cerastium), Purple Astragal (Astragalus), Yellow Oxytrope (Oxytropis), \&c. It is difficult to see any advantage in this plan, for, even if we could overcome our repugnance to such a wholesale innovation, these spurious names are as difficult to remember as the proper scientific ones, and are not nearly so serviceable.

I have no doubt that names are more readily remembered when there is some meaning attached to them, but with a little perseverance they may be learnt even without the advantages of a classical education or the assistance of this book; indeed, many foreign plants are called by their native names, with a Greek or Latin termination. These may or may not have known meanings, but, when they have, these meanings are known only to very few.

We have an illustration of the ease with which botanical names may be acquired, in the success that has followed the labours of the working-men botanists of Lancashire and the adjoining counties. Mr. Grindon* has given an interesting account of them; and he tells us that "the study of botany by the operatives about Manchester, at least in a precise and methodical manner, appears to date from the establishment of the Linnean system." * * * * "The business of the meetings was to compare the floras of the several neighbourhoods, and to exchange plants and information in general on subjects * 'Manchester Walks and Wild Flowers.' 
connected with botanical science." They were held monthly in the sereral villages and towns in rotation ; and ammully, in the summer, there was a general meeting of all the societies, at a different place each year.

This organisation still exists, and an annual meeting was held in July last, at which I. was present. A large number of people assembled, probably orer fifteen hundred. The weather was unfarourable, or, I was told, there would have been more; and that last year there were over tro thousand. A great number of specimens were exhibited and named by the president, Mr. Percival. The members are informed that "as specific discrimination and accuracy in botanical nomenclature are the chief objects sought to be obtained by the aid of the meetings, all persons who attend are hereby respectfully solicited to bring with them such specimens of plants-either indigenous or exotic, but particularly the former-as they can conveniently procurc." These were arranged on a long table, in the tent in which the meeting was held, in the order of the Linnean classes, all of which were represented. Mr. Percival named them in succession, giving first the scientific, and then an English, name. Many of the British plants were either generally rare or locally so, among which may be mentioned Sea Holly, Henbane, Deadly Nightshade, Asarabacca, Red Bryony, and Sea Beet. Besides their names, and whether they were British or exotic, occasional 
mention was made of local habitats. It was provided that the specimens "shall become the property of the President, who shall dispose of them in such a manner as he may think will give general satisfaction;" and it was noticeable that all plants of special interest or rarity were eagerly applied for. I have no doubt that much useful information was carried away from the meeting, and much good feeling was manifested.

It does not appear that the Greek and Latin names have been found of great difficulty to these botanists. It is no easy task for anyone to name rapidly and correctly a number of plants brought indiscriminately from fields, gardens, and hothouses, and some with a mischievous intention to puzzle the President,-such as deformities or sports; but $\mathrm{Mr}$. Percival was seldom at fault; and though his facility is extraordinary, there are numerous other members of these societies who can undertake the same task with credit and success. These societies have always had members of great zeal, industry, and botanical knowledge ; and their labours have been of considerable service to the science. Among them may be mentioned the late Mr. John Nowell, of Todmorden, an operative cotton-spinner, whose contributions to our knowledge of cryptogamic botany are well known. These working-men botanists always begin to learn by having the names of plants told them, and $I$ believe this is both an expeditious and a good plan. 
To ascertain the names of plants from books, which requires careful study, is always the best when it can be done; but this is sometimes a matter of great difficulty, and even expert botanists frequently make mistakes. Some species require to be examined at different seasons of the year, and it does not always happen that a single person can obtain the necessary specimens. He may gather a plant far from home in flower, which will not enable him to determine its species, and he may not have an opportunity of collecting the same plant in fruit. Hence it happens that in many instances, though there are most-carefully arranged artificial keys to help the student to the name of a plant that he may find, as in Bentham's 'Handbook of the British Flora' and Grindon's 'British and Garden Botany,' he is unable to trace it. In such a case I lnow no better plan than to get some one to give the information. It is better, I think, to obtain the name of a plant by any means, than to lay it on one side with the idea of finding it out oneself at some future time, which may never come.

I have not attempted to include all the names that have been given for British plants in my list, but have endeavoured to select those which are now in general use, and which may be met with in the most recent standard works. I know of no acknowledged standard to which we might refer in order to ascertain which out of two, three, or four, is the proper name of a British plant, as though there are 
rules to determine which is correct, they are not adhered to. The 'London Catalogue of British Plants' may be taken as our standard list of plants, but its compiler, Mr. H. C. Watson, does not profess to have named them according to strict rule. He says in his explanation of the 'Catalogue:'-“No rule has been strictly adhered to in the selection of specific or varietal names. The nearest approach to a fixed rule has been to that of using the name deemed likely to be familiar or intelligible to the majority of English botanists. Wilfully to impose a new name on a plant, already sufficiently named, should be treated as an impertinence. On pretence of priority, to rake up and restore an old name which had fallen out of use, should be scouted as mischief. The personal vanity which impels authors into these practices should be denounced as a nuisance. Notwithstanding this expression of opinion, however, the Editor has found himself obliged to adopt some needlessly imposed names, and also some unwisely restored names. Moreover, it may truly be said that the selection of one name, among several bestorved upon the same plant, is often purely optional or conventional, and the selection is not seldom made by botanists, even in breach or disregard of their own rules about priority, \&c. A name once published for any plant is, and remains, one of its names, and may be employed as such, whatever the number of other names which have been subsequently bestowed upon the same plant. Often the 
first name remains the really correct name according to strict rule, although its use is gradually given up by general consent for some newer name. Thus, in these four couplets of names-Erica vulgaris and Calluna vulgaris, Azalea procumbens and Loiseleuria procumbens, Elodea canadensis and Anacharis Alsinastrum, Epipactis atrorubens and Epipactis ovalis-the former of the two is the true and correct name, by rule, while the latter is the name now conventionally adopted among English botanists. In other instances, the choice between two names is purely optional, independently of rules, as between Pyrola uniflora and Monesis grandiflora, Gnaphalium dioicum and Antennaria dioica, Hyacinthus nonscriptus and Endymion mutans, Polypodium alpestre and Pseudathyrium Alpestre."

According to this system the common blue bell may be called indifferently and correctly Hyacinthus, Scilla, Agraphis, or Endymion. In this and similar cases it has been necessary for me to explain all the names. The study of Botany would be simpler if these were not unnecessarily multiplied, and incorrect ones were discountenanced.

In preparing my list I have consulted the standard works that have been published on the British Flora on the modern system of classification, viz., "The British Flora,' by Sir W. J. Hooker and Dr. Arnott; ' Manual of British Botany,' by Professor Babington ; 'Handbook of the British Flora,' by Mr. Bentham; 'Sowerby's English Botany,' 3rd ed., by Dr. Syme; and 'The Student's Flora of the British Islands,' by 
Dr. J. D. Hooker. I have also introduced those names of British ferns which are in general use with fern cultivators, being guided chiefly by $\mathrm{Mr}$. Moore's 'Nature-printed Ferns,' but have not gone into the many synonyms.

Our botanists of to-day find it necessary to reject from the British Flora several plants that were formerly admitted by mistake. Some have only been recorded once several years ago, and the record has not been verified by a specimen: such instances may be fairly judged to be mere blunders. Other plants that have been called British are escapes from cultivation, and some are casual weeds that have sprung from seeds or plants accidentally imported with other foreign produce. Of these, a few have established themselves to such an extent that they may be considered permanent residents or colonists ; as for instance the American plants Claytonia perfoliata and Anacharis Alsinastrum. The 'London Catalogue of British Plants,' 6th ed., excludes 269 species that have been formerly admitted, viz.-of "Aliens, Casuals, Waifs of Cultivation," \&c., 115; and "Ambiguities, Errors, Impositions, Extinctions," 154. I have not purposely omitted the names of any well-known plants, such as Datura Stramonium (Thorn-apple), Polygonum Fagopyrum (Buck-wheat), Narcissus poeticus, \&c., though they are not indigenous British plants.

The present generic names are explained at 
greater or less length by Hooker and Arnott; Mrs. Lankester, in Syme's ed. of 'English Botany;' and Dr. Hooker, in 'The Student's Flora;' but the old substantive names, that are now used as specific ones, are not, so far as I am aware, explained in any modern English book. M. Théis, in his 'Glossaire de Botanique ou Dictionnaire Etymologique' (Paris, 1810), gives great store of information, which has much of it been often reproduced. I have given the names of authorities as the necessity occurs, in preference to giving a list of authors quoted. 


\section{PART I.}

A Shetch of the History of Botany, in reference to Botanical Nomenclature, up to the Tine of LinNeus. 



\section{HISTORY OF BOTANY.}

\section{CHAPTER I.}

FROM THE EARLIEST TIMES TO THE CHRISTIAN ERA.

\section{§1. Early Eastern Botany.}

We know very little about the early history of Botany in the east, beyond the fact that in the most ancient writings plants are frequently alluded to, and as they are necessary to man's existence we must suppose that he had always some knowledge of those which happened to grow in his neighbourhood.

A great number of plants are mentioned throughout the Bible, many of which can still be determined with tolerable certainty, but there are many others about which there is great doubt. We may be sure that at a very early period there was considerable knowledge of plants and their uses among the Hebrews, for we are given to understand that Solomon wrote a comprehensive treatise on them, "from the cedar tree that is in Lebanon, eren unto the hyssop that springeth out of the wall." * Josephus adds " for he was not unacquainted with any of their natures, nor omitted 
inquiries about them, but described them all like a philosopher, and demonstrated his exquisite knowledge of their several properties."* Whether Josephus had any further authority than is to be found in the Bible is doubtful. We are told that the wisdom of Solomon "excelled the wisdom of the children of the east, and all the wisdom of Egypt," from which we may infer that similar knowledge was widely spread. This period was about B. c. 1000. Besides the use of plants as timber, food, and medicine, they probably also played a considerable part in the composition of philters and charms, and in other mysteries of sorcery.

\section{§ 2. Early Greers.}

The traditional history of the science of medicine among the Greeks, if we could accept it as of much value, extends further back than the time of Solomon, for Essculapius, the celebrated, though mythical, physician of antiquity, accompanied, we are told, the Argonautic expedition (в. с. 1263), and was considered so skilled in the medicinal power of plants, that he was called the inventor as well as the god of medicine.

The most ancient writings on plants that have come down to us are those of Hippocrates, who mentions the uses of two hundred and forty. He was born at Cos, a small island in the Grecian archipelago, в. с. 459. He studied physic diligently and attentively, improving himself by reading the tablets in the temples of the gods, where each individual had written down the diseases under which he had laboured, and the means by which he had recovered. He delivered Athens from a dreadful pestilence, and was publicly rewarded with a golden crown, and the privileges of a citizen of Athens. Hippocrates openly declared the measures he had

* Antiquities, Book riii., chap. ii. 
taken to cure a disease, and candidly confessed that of forty-two patients entrusted to his care only seventeen had recovered. $\mathrm{He}$ is said to have lived in the greatest popularity, but was continually employed in careful study of the symptoms and course of diseases, and in applying certain scientific principles, which he had deduced from his observations, to effect their cure. He has been called the father of medicine, for not only is he the earliest scientific writer on the subject, but being a careful observer, and also a sound thinker, many of his teachings have remained as guides to this day. He died в.c. 361, in his 99th year, revered by all, and after his death he received, with the name of Great, the same honours that were paid to Hercules.*

Theophrastus was a native of Eresus, in Lesbos, and was born about B.c. 390. He studied under Plato, and afterwards under Aristotle, and during a long life wrote 200 treatises on different subjects: about twenty of these are still in existence, two of them being on plants. Not being a physician, his 'History of Plants' embraces a larger' view of the vegetable kingdom than the work of Hippocrates. He treats first on physiology, and then goes on to observations on trees, different kinds of timber, and the choice of it; afterwards there is a book on shrubs, thorny plants, roses, and other ornamental plants usually cultivated in gardens, and then follow kitchen garden plants, and those that grow wild, and grain of different kinds: his last book is upon gums and exudations, and the means of obtaining

* As is nearly always the case with respect to very old authors, neither all the incilents that are generally set down of the life of Hippocrates, nor the authenticity of all the works that have been attributed to him, can be implicitly relied on. It has been said that out of seventy-two that at one time or another have been called his, only about one-fourth are really so, 
them. We are indebted to Theophrastus for the preservation of the worlss of Aristotle, who entrusted them to him on his death-bed; he succeeded that philosopher in the Lyceum, where he became so celebrated that his auditors increased to the number of 2000 . He died, according to some, in his 8rth, according to others in his 10rth year, lamenting the shortness of life, and complaining of the partiality of Nature, in granting longevity to the crow and to the stag, but not to man.

There is a little uncertainty as to the exact time of Dioscorides. He is said by some to have been physician to Antony and Cleopatra, who killed themselves B. c. 30 ; by others he is reported, with perhaps more probability, to have lived in the time of Nero, who killed himself A. D. 68. He was a native of Cilicia, and was first a soldier, but afterwards applied himself to the study of physic; being a physician, Dioscoricles treats on plants in respect to their medicinal uses, and his work resembles a modern 'Materia Medica.' It is not confined to plants, but includes mammals, fishes, and insects, with the products derived from them, as milk, butter, cheese, wool, honey, \&c.; minerals are also included. By far the greater part of the work, however, refers to plants, and these are divided in a general way, though not very strictly, into the aromatic, alimentary, and medicinal. Dioscorides is the authority for a great number of our old Greek names of plants, and he has been much read, commented on, and quoted. His 'Materia Medica' was the first of the Greek botanical works which, on the invention of printing, was introduced to western Europe in a Latin translation by Barbarus, a Venetian nobleman; it was printed in 1478 , but a translation of Theophrastus soon followed in 1483 . In 1548 another translation of Dioscorides was published by Matthiolus, an Italian physician : it ran through serenteen editions, though 
a bulky work, and it is said that 32,000 copies were sold before the year 1561. Another and much esteemed edition of Dioscorides, by Caspar Bauhin, was published in 1598 .

These three Greek writers, Hippocrates, Theophrastus, and Dioscorides, are the authorities for all the Greek names of plants up to the Christian Era.**

\section{§3. Latin Writers before the Christian Era.}

There were a number of Latin authors who took great interest in plants, and wrote of them incidentally, and some of them wrote treatises on husbandry. Horticulture was also a farourite amusement of several of the Latin poets; hence it frequently happens, that though these writers can scarcely be quoted as botanical authorities, names of plants which are still in use are to be found first in their works.

Among these the following may be named:-Plautus, a writer of comedy, who died B.c. 18t. Cato, an orator and historian, who died в.c. 150. He wrote a treatise on husbandry, and it is of him that the well-known story is told, that he repented of only three things in his life:-to have gone by sea, when he could have gone by land; to have passed a day inactive; and to have told a secret to his wife. Varro, died B.c. 20; he was a learned writer of 500 different works, all of which are lost excepting one on agriculture. Virgil, the well known Roman poet, died B. c. 19; his famous 'Georgics,' a poem on agriculture in four books, was written at the particular request of Mreenas, a Roman nobleman, who was a great patron of letters. The first

* There were other Greek writers of less note, or who, though of great note (for instance Aristotle), did not contribute rery much to Botany, though they wrote something on the subject. Not a few of their works are lost, therefore I confine myself to these three. A full list is given by Gesmer, in a prefice to the Herbal of Hieronymus Tragus. 
book treats of ploughing, and preparing the ground; the second of sowing and planting; the third of the management of cattle; and the fourth gives an account of bees, and the manner of keeping them. Macer, a poet, who died B.c. 16, was much admired for his genius and learning, and the elegance of his verse; he wrote a poem on Plants. He was intimate with Ovid, who mentions him, but all his works are lost. Columella flourished about the middle of the first century, and wrote a work on husbandry. 


\section{CHAPTER II.}

BOTANY FROM THE FIRST CENTURY TO THE TIME OF THE ARAB PHYSICIANS.

\section{§ 1. First Century. Pliny.}

THE first century of the Christian era is signalized in the history of Botany by the work of Pliny, who set himself the task of recording all that was known or accepted concerning every branch of Natural History, and what we might now call Social Science; a work which he completed two years before his death, and which will ever remain a monument of his intellectual power, his untiring perseverance, and his enormous erudition.

This remarkable man, Caius Plinius secundus, called Pliny the elder, was born either at Verona or Como, A.D. 23. A considerable part of his life was spent in the army, and after he had been made one of the augurs at Rome, he was appointed Governor of Spain; but though much occupied with public work, he was such an enthusiastic student as to devote every moment of his spare time to literature. Even during his meals some book was generally read to him; he always moved about at Rome in a litter, so that the time might not be lost from study, and he disapproved of walking as a waste of time. We are told by his nephew (Pliny the younger) that when in retirement in the country, the time spent in the bath was the only portion that was not allotted 
by him to study, and explains that in speaking of the bath he means the time when he was actually in the water, for while he was being scraped with the strigil* he either . had some book read to him, or dictated himself. A friend once interrupting a person who was reading to him, on account of the mispronunciation of some word, and making him read the passage over again, "You understood him, didn't you ?" said Pliny. "Yes," said the other. "Why then did you make him go over it again? Through this interruption of yours we have lost more than ten lines." It was a maxim of his that no book is so bad but that some good may be got out of it. The number of authors quoter by Pliny has been counted, and found to be between four and five hundred. Buffon writes thus of his 'History of the World ': + - "It is, so to say, a compilation from all that lad been written before his time: a record of all that was excellent or useful; but his record has in it features so grand, this compilation contains matter grouped in a manner so novel, that it is preferable to most of the original works that treat upon similar subjects." Cuvier also places it

*The strigil was an instrument used both by the Greeks and Romans in their elaborate system of bathing, to scrape perspiration and other impurities from the skin after the bath, as our grooms scrape hor'ses, or as the skin is dressed in modern "Turkish Baths." It was a one-handed instrument with a straight handle and a curved blacle, and, as it was not blunt, its edge was softened by the application of oil from a small dropping bottle.

+ Generally called 'Pliny's Natural History.' Can this be called a proper translation of 'Historia Mundi'? -or is it so good a title for a work that includes not only various crowns, and chaplets, and plants used in religious observances, but the price of dining tables, and a (quantity of other matter which the freest stretch of a very elastic subject could scarcely bring within any comprehensible limit of "Natural History"? Humbolit aclopts the happy term 'Cosmos' for his similar work. 
amongst the most valuable productions of antiquity:- " The work of Pliny," says he, "is one of the most precious monuments that have come down to us from ancient times, and affords proof of an astonishing amount of erudition in one who was a warrior and a statesman."

To a modern reader the first impression on taking up the 'History of the World' would probably be one of surprise at the astounding superstition of the time and the credulity of the writer, but further study would cause him to feel that these blemishes are quite lost in the general grandeur of the work. Pliny died a martyr to the cause of science. On the occasion of that great eruption of Mount Vesuvius which destroyed Herculaneum and Pompeii, he was at Misenum, where he commanded the fleet, and being surprised at the sudden appearance of a cloud of dust and ashes, of which he did not know the reason, he immediately set sail in a small vessel for the mountain, which he found to be in a state of eruption. The inhabitants had fled, but Pliny's curiosity induced him to remain all night to make observations, amidst the tremendous and horrible confusion of earthquake, fire, and continual showers of pumice stones and ashes. On the following day, when endeavouring to escape, he sunk down suffocated by the thick sulphurous vapour's that surrounded him, A.D. 78. His attendants escaped, and his body was found three days afterwards.

Pliny was first printed in 1468, since which time there have been several editions. An English translation by Philemon Holland was published in the latter part of the reign of Elizabeth, and we have a more recent one by Dr. Bostock and Mr. Riley, B.A., in Bohn's Classical Library (6 vols., 1855), which is copiously illustrated by notes, references, and comments. 


\section{§ 2. Second Centuru.-Apuleius and Galen.}

Apuleius was born at Madura, a Roman colony in Africa, some time in the second century. He studied at Carthage, Rome, and Athens, and being of a very inquiring mind, travelled about a good deal in different countries,-indeed to such an extent as to spend all his fortune, so that when he would become a priest of Osiris * he had to pawn his clothes to raise the necessary money for the expenses of the ceremonies of his reception. Afterwards Apuleius maintained himself by pleading causes, in which he soon became famous. Lodging some time in the house of a rich widow, called Pudentilla, who was much taken with his youth, vivacity, agreeable conversation, and other attractive qualities, Apuleius married her, not only as we are told to the satisfaction of the widow's eldest son, who was much attached to him, but also at his solicitation. Others of his wife's relations were dissatisfied with the match, and he was involved in a lawsuit, being accused of sorcery. Apuleius defended himself with great ability, pointing out that it did not require the arts of a magician to induce a woman, who had been thirteen years a widow, to marry a person like himself. He also said that his wife was neither young nor beautiful, and stated generally the disadvantages of marrying widows. After this he turned his attention to the study of philosophy and medicine. He wrote a work "concerning the names and virtues of herbs," which gives the names of 130 in Greek, Latin, Egyptian, Punic, Keltic, Dacian, and of some in the Oriental languages which he had acquired in his travels. $\dagger$

* Osiris was a great deity of the Egyptians, of whose origin particular accounts have been giren, but they cannot be said to rest on any sure authority.

t Though it has no connection with Botany, it may be well to mention that, of Apuleius' writings, the most celebrated is an amusing 
Galen (or L. Claudius Galenus) is styled by a high authority "one of the most eminent physicians of any age or country." * He was born at Pergamus, in Asia Minor, A.D. 130. His father was an architect and geometrician, and appears to have been in good circumstances and to have spared no expense in the education of his son, who often mentions him in terms of great affection and respect. At first he was intended for a philosopher, but changed his profession before his father's death (which happened when he was 20 years old) to that of medicine, which he studied for some years with great assiduity in various cities and under the most eminent professors. On his return to his own country in 158 he was appointed physician to a school of gladiators, and in his thirty-fourth year he went to Rome, where he remained about four years, and then left; it has been asserted by some, to avoid the pestilence which broke out there in 167. There is no reason to believe that this was the cause of his departure, though it happened at the same time. Galen could not have led a very pleasant life in Rome, on account of his disputes with the other members of his profession, for which there might be at least two reasons,-first, he was without doubt altogether superior to his contemporaries, then he was himself at times violent and bitter in his language. He had hardly reached his own country when he was summoned by the emperors M. Aurelius and L. Verus to attend them in one of their northern campaigns, and after the death of Verus he remained in Rome some time as physician to the imperial

allegorical piece called the "Golden Ass," one of the few works that have come down to us from the ancients having the character of what we call light reading. It has been commented on by several critics, and translated into different languages.

* Dr. W. A. Greenhill, in 'The Imperial Dictionary of Universal Biography.' 
family. Of the remainder of his life, which lasted thirty or forty years longer, little is known, nor can it be stated with certainty when or where he died. "His personal character may be gathered from his works; and notwithstanding his excessive laudation of himself, and his controversial bitterness, there appear's to have been much in him that was truly admirable. The extent and variety of his intellectual acquirements were very great; and he was not only beyond all comparison the most eminent physician of his age, but also a learned and accomplished man, well acquainted with various branches of philosophy."*

Galen's writings were very numerous, it is said 500 or more, including short treatises. Many of them are lost, being burnt in the Temple of Peace at Rome, where they had been deposited, and it is supposed that several are now lying unknown or unnoticed in different European libraries. About 150 are known to be extant.

Galen had a great admiration for Hippocrates, and acknowledges that he was greatly indebted to his writings for his knowledge of medicine. It is chiefly in his works on anatomy, physiology, dietetics, and hygiene, and the physicians' art generally, that Galen excels. His great work on plants is considered the least important, containing but little original matter, and being in some respects inferior to the work of Dioscorides.

\section{\$3. Fron the Second to the Eighth Century.-Paulus.}

The great renown of Galen and his numerous writings bore absolute sway for many centuries; indeed it is not too much to say that his teachings ruled supreme for 1000 years, and that some of what was erroneous or useless in his system was not superseded before the eighteenth century. I there-

$$
\text { * Dr. W. A. Greenhill. }
$$


fore mention only one physician as having any importance to our subject for six centuries after Galen. This is Paulus, who is not only frequently quoted by the more recent herbalists, but whose works are reckoned amongst the most valuable relics of ancient science by those of our own time, and were considered worthy of translation by $\mathrm{Mr}$. Francis Adams, and were published by the Sydenham Society in 1844.

Paulus Ægineta, or Paul of Egina, because he is said to have been born in that island, was a celebrated Greek physician, about whose life little is known, or precisely the time when he lived, though it is supposed by the best authorities to have been at the end of the sixth or the beginning of the seventh century. His great work, in seven books, which is at once a compilation of pre-existing knowledge and a record of his own observations, - which seem to have been gathered in wide travels through different countries,-preserves his memory in respect, and as he may be hereafter quoted it is necessary to take this brief notice of him; otherwise there would be nothing of any importance to mention between Galen and the Arab physicians. 


\section{CHAPTER III.}

\section{ARAB PHYSICIANS.}

THE disturbed state of Europe, caused by the incursions of barbarous invaders, entirely put a stop to the progress of Greek and Roman learning, and Science took up its abode in more settled lands. The period of the history of Science on which we are entering, is entirely occupied for several centuries by those celebrated philosophers generally known as "Arab Physicians," because they wrote in Arabic, though under this head are classed the writers of different oriental countries, as India, Persia, Nesopotamia, Syria, Arabia, Egypt, Morocco, and latterly their learning was conveyed by the Moors into Spain. They included philosophers of the school of Aristotle, Jews, Christians, and Mohammedans, and their known writers may be counted by hundreds. Most of them studied medicine, though their writings on poetry, religion, mathematics, astronomy, astrology, and chemistry, are not less remarkable. They extended the use of mineral remedies into medicine, and made many additions to the Materia Medica, among which are to be especially noticed several aromatics and mild purgatives, as senna and rhubarb, in place of the more drastic medicines which were, before them, the only ones used. The following substances have been mentioned as additions to medicine made by the Arabs:-_ "Berberries, camphire, cloves, wallflower, Cassia fistula, galangals, hyssop, kermes, lavender, mace, manna, 
Persian manna, mezereon, myrobalans, nutmegs, nymphæa, rhubarb, opium, sugar," gum sandarach, red sanders, sebestens, senna, tamarinds, hops, and zeodary."

It would occupy too much space to enter minutely into this branch of our history, and moreover it is not an easy chapter to write, because of our scant, and sometimes contradictory, information on the subject. There still exist, however, several Arabic manuscripts which give an account of these physicians, and it has been stated that not a few of the mistakes that have been made may be traced to an imperfect knowledge of this language. Edward Pocock, professor of Hebrew and Arabic at Oxford, celebrated for his profound knowledge of Oriental languages, published, in 1672, the text, with a translation, of the Oriental history of Gregorius Abul-Pharadsh, a native of Melitene, in Lesser Armenia, who was born 1226 and died 1286. Another great fountain head of information is a manuscript of Ebn Abu Oseibia, a native of Damascus, who died 1269. This was translated by Reiske, of Leipsic (who died 1774), which work is in the Royal Library of Copenhagen. It has also been treated on by the late Professor Nicol and others. Professor Würstenfeld, of Göttingen, published in 1840 a 'History of the Arab Physicians and Naturalists': it is in a great measure from this very concise work that I have drawn the following information about a few of the most celebrated of those physicians whose writings, through medicine, have a bearing on Botany.

But first it may be as well to give a few words of explanation as to their names, which in the original have very slight resemblance to those that they are best known by, and as I

* Sugar is certainly mentioned and described by Dioscorides and Pliny, but does not seem to have been then in extensive use in medicine, or employed, as by the Arabs, in the preparation of syrups, for which purpose honey was first used. 
do not understand the language I quote Würstenfeld:"The Arabs have no precise hereditary names, but each joins to his own that of his father, to distinguish himself from others who are called by the same; e.g., Mohammed Ben Abdallah, i.e., Mohammed, son of Abdallah, for Ben signifies son. Now on account of the small number of names, it frequently happens that the fathers of two who are named alike have the same names; then, the name of the grandfather is also attached for distinction, e.g., Mohammed Ben Abdallah Ben Omar. If the grandfathers also have the same names they must go still a step further back." *

It appears that another form used by the Arabs, in place of Ben, was Ebn, also signifying son, as Ebn Omar, the son of Omar, which leaves his individuality uncertain. But Ebn is very often used in a wider signification, as "descendant," thus Ebn Zohr, the descendant of Zohr. Such may be looked upon as a kind of family name, and the different members of the family have to be distinguished, either by a personal name, or some distinctive epithet,-for example, Mohammed Ebn Zohr, Ebn Zohr al-Fakih, that is to say learned in the law.

Another peculiarity in their method of specifying a man was to join to his own name that of one whose father he was; Abu signifies father,-for example, Mohammed Abu Abdallah, Mohammed the father of Abdallah; commonly the position of the names is this, that the one to which $\mathrm{Abu}$ is coupled is placed first to avoid mistakes, e.g., Abu Abdallah Mohammed Ben Omar; here Mohammed is the personal name, Omar that of his father, and Abdallah that of his son.

* This is in fact pretty universal as the primitive system of nomenclature, and still obtains in some parts of Lancashire, as illustrated by Collier (Tim Bobbin), when a boy is made to give his name as "Jone's o' Lall's o' Simmy's, o' Marriom's o' Dicks o' Nethon's o' Lall's o'Simmy's ith' Hooms." 
But it is not always the case that the word set beside Abu signifies a son, for there are also allegorical names formed in this way, as, Abu I-Berakat, which means Father of Blessings. These names formed with $\mathrm{Abu}$ are often placed alone for the designation of a person, the personal name being omitted, as Abu Merwan, and should such a man have another son he can also be indicated in this way, -Ebn Abu Merwan, who must be the brother of Merwan. The Arabic article is $a l$, and is always better retained than omitted in those names of which it forms a constituent part, as, for example, al-Câsim: with the word Abu it coalesces, and becomes Abul, instead of Abu-al,--for example, AbulCâsim. In pronunciation the $l$ of the article assimilates itself to any of the following sounds, $r, l, n, s$, and $t$, 一thus al-Razi, say ar-Razi, and it is the same in the middle of a word, as Abd al-Rahman say Abd ar-Rahman, or Abdorrahman.

Not to pursue this subject to too great a length, a few examples will sufficiently illustrate other methods of forming names :-

From birthplace, al-Bagdadi, the native of Bagdad.

From country, al-Misri, the Egyptian.

From tribe, al-Kinani, of the tribe of Kinana.

From personal peculiarities, al-Dschahidh, he with the prominent eyes.

From an occupation,Ebn al-Attar, the son of the apothecary.

From religious sects, al-Schafeï, of the sect of Schafeï.

Names of honour, Dschemal ad-Din, ornament of religion.

The original names have become considerably altered, in appearance at least, by people of clifferent countries, though there may be no great difference in sound, as one example will be sufficient to show. What the Germans wrote Dschaber, or Dschabir, the English wrote Jaber, the French Djaber, the Italians Giaber, others Gaber; and thus Geber has become the universal appellation of the celebrated alchemist. 
I have ventured on this digression because I have found myself that this short description of the Arabic names removes their entire incomprehensibility, and helps to bring these physicians before my mind more really and more distinctly. The names in full are, however, very long, and as they are of no particular interest to us, fully expressed, I shall use only the contracted forms by which the authors of whom I write are most generally known. A single illustration will show the advisability of this course. The complete name of Avicenna (I quote from Pocock) was " Abu Ali Al Hosain Ebn Abdollahi Ebn Sina Al Shaich Al Raiis (as you might say chief doctor; hence he is commonly distinguished as Princeps)." The contracted form is simply Ebn Sina, which is sufficient, for, though titles of distinction are interesting, if understood, they are not so if one does not know what they mean.

As early as 718, or thereabouts, Ahmed Ben Ibrahim, a physician, wrote a work on herbs and plants used in medicine; and a botanist, who travelled far in his researches, called Ebn Abu Zaher, also wrote a book on plants about 742 , but it was in the following century that Arab learning acquired a great impetus.

About the year 820 the Caliph al-Mamum sent for all the best books out of Chaldea, Greece, Egypt, and Persia, relating to physic, astronomy, cosmography, chronology, music, \&c., and pensioned a number of learned men skilled in the several languages and sciences, to translate them into Arabic, by which means the foundation of modern Arabic learning was laid. Also several of these works, the originals of which are lost, have been preserved to us in these Arabic translations.*

$*$ It is interesting to note the coincidence that while, or nearly at the same time that, al-Mamum was encouraging learning by the means montioned, and founding a seat of learning at Bagdad, our own 
Great among these philosophers was al-Kindi, called Alchindi, or Alkindus. He was born at Bassora, and was of noble blood, reckoning among his ancestors princes of Jemama and Bahrein. He stayed some time at Bagdad, induced by the Caliphs al-Mamum and al-Motasim, who reigned from 813 to 841 . He seems to have lived until about the year 873. His writings, which hare been set down at over two hundred, are on various subjects, many on medicines and the treatment of diseases.

Yahya Ben Mâseweih, called Mesue the elder, came from Dschondeifabur, where his father was an apothecary. He became director of the hospital at Bagdad, and was for half a century physician to the Caliphs from Harun, ${ }^{*}$ who particularly employed him in the collection and translation of Greek works, to al-1Lotewekkil, and he died 857 at Samara.

To this period also belongs Abu Zeid Honein al-Ibad, $i$.e., of the Christian-Arabian family Ibâd, which dwelt in and about al-Hira; he is known by the Latinised name Johannitius, or simply as Honein. He was born at al-Hira, where his father was an apothecary, in the year 809, and when he was grown up, and had received a good education, he went to Bagdad, where he attended the lectures of Mesue (just mentioned), whose amanuensis he became. In a while he was led by his thirst for knowledge to visit the Greek towns, where he perfected himself in their language. Afterwards he went to Bassora, in order to perfectly master the Arabian language, and then returned to Bagdad as his permanent residence. Here he began to give medical lectures,

noble Fing Alfred the Great was himself translating works into Anglo-Saxon (among which were 'Esop's Fables' and 'Becle's History of the Saron Church'), and founding the Unirersity of Oxford.

* Harun al-Rashid is well known to all reaclers of that inimitable work 'The Arabian Nights' Entertainments.' 
and even old and celebrated physicians felt no shame to attend them and learn from him. Shortly he attracted the attention of the Caliph al-Motewekkil, who, after he had clearly convinced himself, by a strict inquiry, that he was not secretly in the service of the Greek kings, appointed him his physician, with a handsome pension. In a while one Abu-al-Teifuri, incited by jealousy, found a device to ruin him. At that time reverence for images had already crept into the Christian church; Honein, who was a deacon, strenuously opposed it, and $\mathrm{Abu}$ al-Teifuri knew that he had once said at a meeting that he spat on the image of Christ or of Mary. So he lodged a complaint, first to the Caliph alMotamid and afterwards to Bishop Theodosius, who then pronounced excommunication on Honein; he died shortly afterwards of grief, or by taking poison, 873. Honein was of great service in his translations from the Greek, in which language he also gave instruction to the youth of his time, especially to his sons and nephews; he also wrote many original treatises on various subjects. His sons followed in the steps of their father, as physicians and translators, and one at least as an original writer. Mention is also made of a son of Honein's sister, who was an author.

Hitherto but few born Arabs or Mohammedans had turned their attention to the study of medicine, by far the greater number of Arabic writers being Christians, but now we not only find independent inquiry among the Mohammedans proper, headed by the illustrious al-Razi, but also a great spread of learning in the west, in Mauritania and in Spain.

Rasis, Rhases, Rhazes, or Razi, was born and brought up at Rai, in Chorasan, from which place he took his name. He showed from his youth a great inclination to Science, and acquired considerable philological and philosophical knowledge; but music charmed him most, and he was known only as a good singer and performer on the cithern 
till his thirtieth year, until which time, also, he was engaged in commerce. Getting tired of this manner of life he turned with all his zeal to the study of medicine and philosophy, and went to Bagdad to study.

After he had gained a thorough knowledge of these subjects, he returned to Rai, and became director of its hospital. Later, the chief direction of the hospital of Bagdad was assigned to him. Al-Razi has been called the Galen of the time, and was held in high esteem by the rulers of his day; he made extensive journeys abroad, not only visiting Jerusalem, but proceeding also to Africa, where he entered the court of Zijadetallah.

He would present his 'Confirmation of the Chemical Art " to a prince of Chorasan, al-Mansur (to whom he had already dedicated the medical work 'al-Mansuri'), and went over to him from Bagdad for that purpose. The prince was much pleased, and ordered that 1000 pieces should be given to him; but he desired also to see a test of the discoveries that were set forth in the book, and he granted a considerable sum to provide the necessary apparatus,-but the experiments would not act! Gentle readers, have we not all seen similar cases? But then we are not all eastern potentates: al-Mansur was angry, and said:- "I could not have believed that a scholar would find satisfaction in confirming lies by means of books, giving them a philosophical colouring, in consequence of which men may waste their time without profit; I have rewarded you handsomely for your pains with 1000 pieces, I must now punish you for your confirmation of these lies," - with which words he raised his staff and hit him on the head; then he bade him pack up his traps quickly, and sent him back to Bagdad. From this blow hydrophthalmia (or watery eyes) set in,* and by degrees

* According to other accounts this disease of the eyes was brought on by his inordinate consumption of beans! 
he became blind. At first he thought to have submitted to an operation, but when he asked how many membranes the eye had? and could not obtain an answer, al-Razi said, "Whoever does not know that shall bring no instrument near my eyes," and when they still made representations to him that the operation might be successful, he rejoined, "I have seen so much of the world that you only bore me."

Al-Razi was very charitable, and often gave money to the sick poor while he lived in poverty himself. He died at Bagdad, or in Rai, either in 923 , or more probably in 932 , in extreme old age. We have the titles of over two hundred of his works, on food, on medicine, anatomy, astronomy, mathematics, logic, religion: treatises and commentaries without end. Nothing seems to have been too great or too small for his comprehensive genius, from the most abstruse subjects to "the eating of fruits before or after meals." $\mathrm{He}$ wrote many treatises on food and medicine, a work on aromatic seeds and roots, another on edible fruits, wine, dc.

Yahya Ebn Serapion, usually called Serapion the elder, was a Syrian physician, and a contemporary of al-Razi, who often quotes him. Nothing is known of his personal history.

In this period the study of Science attained the summit of its perfection throughout the whole of the Mohammedan world, in the East, in Egypt, Mauritania, and Spain, many eminent physicians adorning all the various seats of learning. Mesue, the younger, a Jacobite Christian," was born at Maridin, on the Euphrates, and studied medicine and philosophy at Bagdad. He afterwards went to Cairo,

* These Jacobites were so called after Jacob Baradxus, a Syrian, who in the sixth century vigorously defended the doctrine of Eutyches, an abbot of Constantinople, in the fifth century. This cloctrine is, that there was but one nature in Christ, the human having been absorbed in the divine. 
where he obtained a very good situation under the Caliph al-Hakim. He died 1015. His works do not seem to be now in existence in the original Arabic, but there are Iatin translations of three of them on medicines.

We next come to Ebn Sina, or Avicenna. Avicenna was the most renowned of all the Arab physicians. He was born in the province of Bochara, 980. Being naturally precocious, and receiving early a good education, he soon became a miracle of erudition, insomuch that in his tenth year he knew the Koran, and several philological works, by heart. He next studied politics and arithmetic, under competent teachers. About this time a philosopher called Abu Abdallah al-Nâthili went to Bochara, and was employed as Avicenna's tutor by his father; but the pupil was soon in advance of his teacher, and answered his questions better than he himself knew how, and when they turned to logic Avicenna found that his teacher knew nothing at all about its niceties: Al-Nâthali did not long continue his tutor. Avicenna's studies proceeded in mathematics, physics, metaphysics, and medicine, until he was sixteen years old, when his ardour is represented to have become something altogether extraordinary. He scarcely slept at all, working day and night, and when he came across a difficulty that baffled him he frequently betook himself to the Mosque, and sought assistance in prayer. He had the good fortune to be appointed physician to the Sultan Nuh Ben Mansur, and obtained permission to make use of his splendid library, where he found books of which most men had never heard even the titles, which he had never before seen himself, and which he never saw after. We may imagine the assiduous study that he would give to this library. As unfortunately it afterwards happened that this invaluable treasure of learning was destroyed by fire, the enviers and enemies of Aricenna asserted that he had himself burnt it, so that he 
might be sole possessor of the knowledge which he had drawn from it, and could give it out afterwards for his own.

At the age of 18 he is said to have gained a perfect knowledge of the whole circle of the Sciences, - to have known in fact all that could be known in his day from books. Pity that such a gigantic intellect, and such untiring industry, should not have been more devoted to independent research.

It is not necessary for us to trace all the vicissitudes of Avicenna's eventful life; at one time a Kadi held in great esteem, at another in disgrace, and concealed to preserve his life; but, through it all, doctoring, lecturing, and writing, first at one court and then at another, until his death at Ramadhan, 1037. Though naturally of a strong constitution Avicenna gave way to excesses which damaged his health, and probably led to his death at the comparatively early age of 57.

Dr. Nichol (in the 'Imperial Dictionary of Universal Biography') speaks thus of his writings :- "Of his gigantic works-numbering more than a hundred-any one was suffcient to establish a reputation; nor was any Science known in his time which in some manner he did not advance." Würstenfeld gives a list of one hundred and five of his works, and remarks that some of them are very voluminous, while others are only short treatises of one or two sheets.

Serapion, or as he is usually called Serapion the younger, to distinguish him from the Syrian physician of the same name already mentioned, cannot have flourished earlier than the end of the eleventh century, for he quotes Ebn Wâfid (Abenguefit), a physician of Toledo, who was living 1068. The Arab biographers and historians give no account of him. He wrote a work which has been translated into Latin under the title 'De Medicamentis Simplicibus,' or' 
concerning "simple medicines," or shorter "simples," or as we should say a "Herbal." I quote this Latin title because it is a very common one, and a great number of these physicians wrote 'de Medicamentis Simplicibus' under its Arabic equivalent. The writing of Herbals continued for some hundreds of years after the decadence of Arab learning, in different countries-in fact into the eighteenth century, all of them marvellously alike.t The writings of the eider Serapion and those of the younger have been frequently bound up together, as though they were the work of one author.

There were several physicians of the twelfth century who among other subjects treated on simples; the most celebrated of them being Ebn Roschd, or Averroes. He was born about 1120 at Cordova, where he was also brought up. But little is known of his personal history; he was learned in mathematics, philosophy, and medicine, and, as well as his father and grandfather, held important offices of State. At one time he was Kadi of Seville, at another of Morocco, and was universally much respected; but he suffered the penalty common to court favourites, - he had enemies, and they * "Simples; Plyysical herbs, probably so called as being the chief ingredients of which compound medicines are made.

$\left.\begin{array}{l}\text { Simpler } \\ \text { Simplist }\end{array}\right\}$ one who has skill in simples, or a gatherer of herbs.

Simpling; gathering of simples or physical herbs in the field."Bailey's Eng. Dict., 1731.

t The old form of "Herbals" has now gone out of fashion, to give place to "Floras," which, while they enter minutely into the most trifling differences in various organs of insignificant weeds, take no note whatever of the uses of plants to man in the way of food, medicine, or anything else. Of course it may be said that Botany is now recognised as a Science, of which there are many divisions, which is no doubt true; still it is a fact that Economic Botany, which one would think the most important branch, has latterly received but little attention in England, while we have been deluged with "Floras," all excellent but most of them substantially alike. 
made it out that through his studies of the old philosophers his judgment had become warped, and he was no longer a good Mussulman: and so he with some others, narrowly escaping death, was banished from Cordova, but he was shortly recalled. He died at Morocco, 1198.

\section{Thirteenth Century.}

This is a period of copying, when there were very few original writers. Having reached its climax in the foregoing: century, Arab learning now began to decline, and continued to do so until its extinction.

Mansur Ben Abul-Fadhl Ben Ali, a learned Syrian physician, who died 1241, wrote for the Sultan al-Malik al-Muaddhem 'De Medicamentis Simplicibus,' in which he introduced much that was new or had not been noticed by his predecessors.

We now come to the most eminent of Arab botanists, Ebn al-Beitar, who was born at Malaga. He went to Egypt, where he was received with much honour, and travelled afterwards in Greece and Asia Minor, for the increase of his botanical knowledge. Ebn Abu Oseibia (the biographer already mentioned and to be shortly noticed) was acquainted with him in 1235, and often made botanical excursions with him in the neighbourhood of Damascus, receiving great benefit from his instructions. After other travels Ebn alBeitar returned to Damascus, where he died suddenly, 1248.

I have at the outset mentioned Ahmed Ben Ibrahim and Ebn Abu Zaher, as botanists who wrote on plants as distinguished from the study of physic. Since that time (eighth century) Botany should rather be called simpling; but in Ebn al-Beitar we seem to have more of what we should now call a botanist. Probably he stands thus prominently before us because the historian, Ebn Abu Oseibia, was intimately acquainted with him; and it is 
likely that many others were true botanists also, but embodied all the results of their botanical explorations in their works "de medicamentis simplicibus."

Ebn Abu Oseibia was born at Damascus, where his father was an oculist, and his uncle director of the eye hospital. We have just noticed his botanical studies under Ebn al-Beitar; he also studied philosophy and medicine. In 1236 he was employed in the hospital at Cairo, but went the following year to Sarched, in Syria, in the service of the Emir, and died there 1269, over seventy years of age. His most remarkable work is a history of medicine: to show the importance of this work I quote from Würstenfeld an abridged account of its contents, taken from the writings of Reiske and Nicol, with the remark that some names are mentioned by Nicol that are omitted by Reiske, and vice versî. I omit the names altogether, as unnecessary to our subject, recording only the number of authors.

Chapter I.-Origin of medicine.

II.-The first physicians and discoverers of medicine.

III.-The Greek physicians after Æssculapius.

IV.-Hippocrates and his disciples: Empedocles, Pythagoras, Socrates, Plato, Aristotle, Theophrastus, Alexancler Aphrodisiensis.

" V.-Galen and his contemporaries.

"VI.-The Alexandrian and contemporary Christian physicians.

"VII.-Arab physicians to the time of Mohammed. . 10

", VIII.-Syrian physicians under the family of Abbasides. . 34

IX.-Translators and their patrons. • . . . 48

" X.-Physicians of Irac, Mesopotamia and Dijarbekr. . $\quad 77$

" XI.-Persian plysicians. . • • • • . 23

", XII.-Indian physicians. • • . . . . $\quad$ • 7

, XIII.-Western physicians.

Of Mauritania $\quad \cdot \quad \cdot \quad \cdot \quad \cdot \quad \cdot \quad 3$

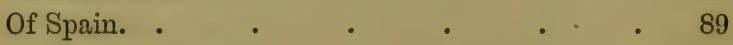

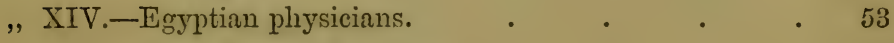

"XV.-Later Syrian physicians . . . . 58

In all . . . . . . . . 402 
Living at the same time as Ebn Abu Oseibia was Abul Faradsch Dschordschis (rather a roundabout way of spelling George), or Gregorius Bar Hebrïus. $\mathrm{He}$ was born at Melitene, in Lesser Armenia, 1226. From his youth up he was practised in the Syrian, Arabic, and Greek languages, and studied theology, philosophy, and especially medicine, under the best masters. When the Tartar's penetrated into Armenia, he removed with his parents to Antioch in 1241, where he led for some time the life of an anchorite, in a cavern near the town. In the following year he went to Tripoli, and was ordained bishop of Guba by the patriarch Ignatius, the next year bishop of Lacaba, and in 1252, by Dionysius, bishop of Aleppo. The patriarch Joshua raised him in 1264 to the dignity of primate of the Jacobites, and after obtaining considerable relief by his efforts for the Christians, who were then much oppressed by the Moguls, he died at Meraga, 1286. Besides his oriental history Gregorius wrote theological, grammatical, mathematical, astronomical, medical and other works, as well as commentaries on Hippocrates, Dioscorides, Galen, Honein and Avicenna.

After the middle of the fourteenth century there was a great falling off in Arabic literature, though we have the writings of several physicians more or less celebrated up to the sixteenth century, when, however, learning had become much more widely disseminated, and the Latin language became universal, or nearly so, among the scientific writers of all countries, being much more generally understood than Arabic. Extending as they do over such a length of time, and treating on such a number of subjects, it is difficult to estimate the value of the labours of these great philosophers. Besides being voluminous writers of commentaries on the Greek and Roman authors, they did much to advance every known Science. We are told* they measured the circum-

"Dr. Draper, "Conflict between Religion and Science," Chap. ir. 
ference of the earth, making it about 24,000 of our miles; ascertained the length of a degree right within one-third of a mile; translated the chief Greek philosophers into Arabic ; produced numerous writings on mechanics, hydrostatics and optics; invented apparatus for distilling, fusing, \&c.; produced great improvements in geometry; invented algebra; and especially improved chemistry, preferring experiment to speculation. They first established medical colleges, introduced the Indian numbers, made catalogues and maps of the stars, fixed the length of the year, and verified the precession of the equinoxes. They first used the pendulum as a time measurer, discovered sulphuric acid, nitric acid, and alcohol, first published pharmacopœias, and included in them minerals. In agriculture they improved irrigation, the method of employing manures, and the breeding of cattle. In manufactures they made Cordova and Morocco leather and paper, and Toledo blades, and improved mining. They taught Europe chess, and gave it its taste for romances and music of a high order.

With regard to Botany there were, as we have seen, many writers, and we also find several important additions to our knowledge; still, taking into account the information they obtained from Galen and others, and the long period of time, the progress made was not so great as might have been expected, especially when compared with their great achievements in other Sciences. 


\section{CHAPTER IV.}

REVIVAL OF BOTANY, AND ITS HISTORY TO THE SEVENTEENTH CENTURY.

§1. From the Arab Physicians to the Sixteenth Cextury.

THere is nothing worth notice in the history of Botany from the time of the Arab physicians until the invention of printing. It seems necessary, however, to mention a work called 'Macer's Herbal,' which appeared in England in the fourteenth century. It is supposed to have been the work of a French physician, and was written in Latin. It was translated into English by Mr. John Lelamer, Master of Hertford School, who lived about 1373, and on the invention of printing two editions of it were published. It was commented on by the celebrated Linacre, physician to Henry VIII., and founder of the College of Physicians; he was also a friend of Wolsey, Erasmus, and Melancthon. Though this Herbal received so much notice, and was for some time popular in England, it was of little merit or consequence, and contained accounts of only eighty-eight plants.

The invention of printing soon gave rise to fresh activity; the best works of the ancients, which had become almost forgotten, were speedily printed, eagerly studied, and called forth a number of commentaries. Pliny first appeared in 1468 , and Dioscorides (translated into Latin) in 1478; a Latin translation of 'Theophrastus was published in 1483. 
I cannot help attributing the great botanical activity of the sixteenth and succeeding centuries also to the discovery of the New World. The vast accession of fresh plants, far exceeding in number all that were known before, many of them supplying articles of food or luxury, and some of them flowers of fresh form or rare beauty, caused people of wealth and refinement to take an increased pleasure in the cultivation of gardens, and patrons of learning to employ those who were learned in Botany to superintend their management: many of these gardens were more specially devoted to the cultivation and study of plants useful in medicine, and were called physic gardens. In England we had also a greatly increased attention paid to the cultivation of kitchen garden plants and orchards, stimulated in no small degree by Anne of Cleves, who, after her separation from Henry VIII., amused herself much with gardening, and imported many choice plants from Flanders, where the art was well understood.

\section{§ 2. The Sixteenth Cenntury.}

It is not within the scope of this little work to enter upon the history of modern classification. Such an undertaking would far exceed the limits I have appointed for myself in regard to space. With the abundance of material at hand from this time, it is somewhat perplexing to make a judicious selection, for on the one hand to attempt too much would be to make a mere list which would be neither interesting nor instructive, on the other to omit particular mention of some great names would be justly complained of. I therefore propose to confine our history from this point as much as possible to Botany in reference to the nomenclature of the British Flora, and with a few exceptions not to extend it beyond the time of Linneus. I take this course the more readily because it does not substantially interfere with the 
intention of this article as a popular sketch, having no pretension to be exhaustive, but aiming at being suggestive only. In Gray's 'Arrangement of British Plants' (1821), there is a list of botanical publications from the first printed edition of Pliny, 1468, to 1820, which, though by no means complete, will sufficiently illustrate my meaning. In the fifteenth century I find 8 botanical works; in the sixteenth, 24 ; in the seventeenth, 68 ; in the eighteenth, 235; and in the nineteenth, up to $1820,92$.

We may conveniently commence the sixteenth century by the notice of a curious, but not botanically important work, called the 'Grete Herbal,' which appeared in England 1516. It was very popular, and passed through several editions. We know nothing about it beyond what we are told in the book itself, viz., that it was translated from the French, and printed in London by John Kynge. It is printed in black letter, and the earlier editions are illustrated with rude woodcuts, which are less numerous in later impressions; many of these pictures resemble nothing in Nature, and in some instances the same is made to do service for different plants. Though possessing so little merit as a botanical work, the 'Grete Herbal' is of interest, if only on account of its being the first (excepting Macer's 'Herbal,' which is worth no further notice than we have already taken of it), and for half a century the only botanical work in the English language.

The chapters are arranged alphabetically, according to the Latin names, and this is notified at the end of each division thus:- "Thus endeth the chapiters of herbes beginning with $\mathrm{A}$. And here begynneth the chapitres named with B."

"De Balsamo. Bawme tre."

Following the heading of each chapter there is a paragraph briefly describing the plant, and telling us of its 
habitat and its temperature,* with a general statement of its uses in medicine; but the greater part of the work is made up of the various complaints that each plant was used for. These are set down separately, after the description of the plant, with the manner of application. Many of these remedies are rather amusing, and an illustration or two will not be out of place. It is the idea at the present day that if one would avoid drunkenness the best plan is to avoid drink; but it appears that in the days of Henry VIII. the same object was attained in another way :-

"For dronkennesse.

"To eschewe dronkennesse, drink ye iuce of bryony with as moche vineygre and he shall not be dronke of all that weke."

" It seems necessary to explain what is meant by the " temperature" of a plant, for it is a term that is used in all the "Herbals." It originated from a maxim of Hippocrates, who laid it down that our bodies are governed by a principle that he called Nature, and when he comes to explain more particularly what this Nature is, he resolves it into heat, which he looked upon as having something immortal about it. Then he held that contraries or opposites are the remedies for each other; thus heat was destroyed by cold, and cold by heat, \&c. In the treatment of diseases he did not depend greatly on physic, but much on diet; still either in the one case or the other he followed out this principle; to oppose the hot to the cold, the moist to the dry, and vice versia. The idea of ascribing a certain degree of "temperature" to a plant remained until quite recently. It refers to the effect which a plant has on the temperature of the human body, and it was measured in four degrees. 1st. The same heat as the body, and useful to restore heat when it is wanting. 2nil. Hotter, and causing a gentle perspiration, and, as the expression used to be, "removing obstructions, and cutting thick humours." 3rd. Causing riolent perspiration, and having the repute of resisting poison. 4th. Such plants as blister the skin when outwardly applied. 
Then for the bite of a mad dog (surely there is no complaint for which there are more remedies) this I think has fallen into neglect, and may be new to some of my readers :-

"For bytynge of a wood* dogge.

"And if they" (walnuts) "be stamped with salte and an onyon they be good for bytig of a wood dogge yf it be layde thereto."

This is a remedy which is certainly as well worth trying as most that we have heard of since.

Though the 'Grete Herbal' is now, and has for some time, been little thought of, three centuries and a half ago it was different. The book ends with the pious flourish which will be found on the following page.

On the Continent of Europe there was at this time a great amount of scientific botanical investigation. Otho Brunfels published his 'Herbarium' in 1530, and this was followed by a work of Valerius Cordus in 1536, called 'Dispensatory, or Pharmacopœia'; the learned Gesner also published a 'History of Plants' in 1541.

* "Wód," pronounced wood, is Anglo-Saxon for mad, and is frequently to be met with in old English writings, as the early English metrical romances. For instance we have in 'Richard Coeur-deLion':-

"The swarte vis when the king seeth, His black beard and white teeth, How his lippes grinned wide, 'What devil is this?' the king cried, And gan to laugh as he were wode." "What? is Saracen's flesh thus good?" \&c. Ellis's 'Early English Metrical Romances.'

Collier, in his illustration of the Lancrshire dialect (Tummas and Meary) has this word, and I have little cloubt that it is still in use in out of the way places. It is interesting to note that it was falling out of general use about this time. I hare two editions of the 'Grete Herbal,' the earlier one (from which the above quotation is taken) has "wood" the other "mad" dogge. 


\section{14 of os 10}

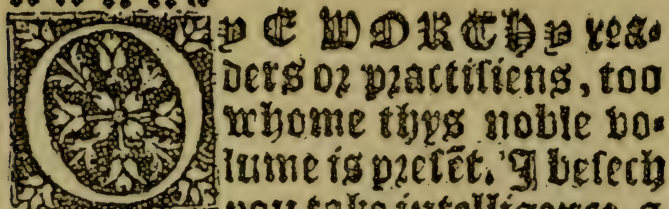
4. beholoe the wookesatso operactons

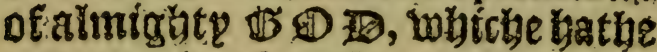
endo toe by fymble creature ntan. fiptio, with the graces of the boly Ghoofte to hatse partpte Hnowlege and broettamdirge of the bertue of all ntanet ofberbes atio trees, ti chys bolie competjended, andetres cpcbe of they cuaptited by then Ielfe anta in etter. cyapytce dis Hers clature, tohertn ts thes

wod Dituers mamer of medecynes ít one berbe compzetje $=$ DeD, wypche oughto to be notefied atid matied foz

the bealib of $\mathrm{ma}$ it witsome ís repedoco the heately guftes by the cternall tunge, too whome be Iauoe arbo yzaขte cueclattus.

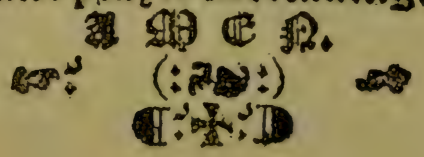


Otho Brunfels was born about the year 1464, in the neighbourhood of Mayence, and died at Berne, 1534. He was a physician, who restored the study of practical Botany in Europe by his direct investigations in the fields.

Valerius Cordus was born at Simtshausen, in Hesse, 1515, and received the rudiments of his education at Erfurt, and afterwards studied at the University of Marburg, where he took the degree of bachelor of medicine. In 1531 he went to Wittemburg, and studied under Melancthon. $\mathrm{He}$ travelled in Prussia, Saxony, Switzerland, and Italy, and it was while journeying to Rome that he was seized with fever and died, 1544, at the age of 29 . His early death was considered a great loss to Science. Of his numerous works 'A Pharmaceutical Dispensatory,' 'Annotations on Dioscorides,' and a 'History of Plants' may be particularly mentioned.

Conrad Gesner was an eminent physician and philosopher' of Zurich. He studied at different seats of learning in France, but returned to Zurich, where he was made professor of philosophy; he was a voluminous author, and from the great extent of his attainments has been called the German Pliny.

I next notice Fuchs, taking these contemporary authors in the order of the publication of their works, rather than the date of their birth. Leonard Fuchs, a celebrated physician and botanist, was born at Wemdigen, in Swabia, 1501, and died at Tübingen, 1565. His ' History of Plants' was published in 1542 ; it is illustrated by outline plates, which have been much admired for their faithfulness. The object of the work is to describe exactly the plants used in medicine. The chapters are arranged in sections, as was usual at that time; the first treating on the names in different languages, with their derivations and meanings; then follow the different kinds, and descriptions of them, and afterwards the habitat, time of flowering, and temperature; 
and last, the virtues, according to Dioscorides, Pliny, Galen, and others. The Fuchsia was so named by Plumier in honour of Fuchs.

Pietro Andrea Mattioli, or Matthiolus as he is called in Latin, published his 'Commentaries on the Materia Medica of Dioscorides' in 1548, as was previously mentioned. He was an Italian botanist of great repute, born at Siena, 1500 , and died at 'Trente in 157\%. His 'Commentaries' form a very fine work, and the illustrations are beautifully executed. He freely attacks the opinions of both older and contem. poraneous writers, perhaps especially Fuchs. The genus Matthiola is named in honour of him.

We have next a writer of our own country of whom we may be justly proud-William Turner. During the time when, as we have just seen, the study of Botany was making great strides abroad, England was remaining in a state of comparatively abject and lamentable ignorance, unrelieved by any intelligent work on the subject, excepting a treatise by Judge Fitzherbert, 1534, on husbandry. Turner says, "Being then a student of Pembroke Hall, where I could learn never one Greke, neither Latin, nor English name, even among the physicians, of any herbe or tree, such was the ignorance at that time; and as yet there was no English Herbal, but one, all full of unlearned cacographies, and falsely naming of herbs." William Turner was a divine, physician, and naturalist, and was born at Morpeth, in Northumberland, about the beginning of the sixteenth century. He studied both in England and abroad, spending some time in Germany and Italy. He was imprisoned by Bishop Gardiner for advocating the principles of the Reformation, and afterwards suffered persecution in Queen Mary's reign, which caused him to leave England; but on the accession of Queen Elizabeth he returned, and was restored to those preferments of which he had been deprived. The 
first part of his 'Herbal' was published in 1551, and the complete work, which he dedicated to the Queen, in 1568. The scientific acquirements of Turner were extensive and various, and his publications numerous. Turner's is generally called the first English Herbal, but mention is made of a small one written previously by Anthony Ascham, vicar of Burniston, in Yorkshire. This, however, must have been a work of but little consequence, for it is generally overlooked, and I have not met with even a description of it. After Turner the study of Botany spread rapidly with us.*

Jacques Dalechamp, or Dalechamps, the authority for several of the names of our British Flora, must be mentioned here. He was a French physician and botanist, and was born at Caen in 1513. He made a collection of plants in the neighbourhood of Lyons, and published a 'General History of Plants,' giving descriptions of over a thousand. Dalechamp also published an edition of Pliny. He died at Lyons about 1588.

Adam Lonicer (in Latin Lonicerus) was another botanical writer of this time. He lived at Frankfort, and published there a work on "Natural History," which is a similar Herbal to others of the same period. In respect to type and illustrations it is rather uncouth; it was published at

* A writer in 'The Garden' (1874) notices the plants that are incidentally mentioned by Shakespeare, who wrote a little after Turner's time, being born 1564:- "Of our English wild flower's Shakespeare mentions about 15, alluding to some only once or twice. Of exotic flowers, or such as were cultivated in the scanty gardens of his period, more than 300 years ago, he mentions nine or ten. Of trees and shrubs, exotics included, there are notices of about 25. Of fruits, whether ripened in England or imported from foreign countries, I find the names-sometimes often recurrent-of about 30. Vegetables are spoken of in about equal proportion. Products of the nature of spices and medicines are mentioned to the extent of about a score ; and the same is about the number of what are contemptuously called 'weeds,'-or about 150 in all." 
Frankfort in 1551. Lonicer was born 1528, and died 1586; the genus Lonicera was named in his honour.

About the same time, and until the end of the sixteenth century, there were a number of celebrated botanists, who aided in the advancement of the Science. Though they followed for the most part in the footsteps of their predecessors, they published some fresh ideas and described some fresh plants, and, though they did not establish an epoch in our history, they introduced improvements in classification, and added greatly to botanical knowledge by the cultivation of physic gardens. We notice the following well-known and frequently quoted authors:-Tragus, Dodonæus, Lobelius, Cæsalpinus, Columna, Camerarius, Prosper Alpinus, Gerard, and Clusius.

Hieronymus Tragus* was a German botanist of this period. He published in 1532 his 'History of Plants,' arranging them under three classes, founded on their qualities, figure, habit, and size, which plan was followed by most other botanists of about that time. This work was first published in German; but a Latin edition of it, by David Kyber, was published at Strasburg in 1552, with a preface by Gesner attached.

Reinbert Dodoens, or in Latin Dodonæus, a Flemish physician, was born at Mechlin, 1518, and died at Leyden, 1585. He published different botanical works, the principal being his 'History of Flants,' a Herbal very similar to others of the same time in most respects, but a fine work and well illustrated; it appeared complete, with 1305 figures, in 1583. There is also another edition, revised by the author shortly

*A Latin travesty of his real name, Jerome Bock, or Bouc, these words signifying "goat," which in Latin is "Tragus," as thougl "Fuchs" should be called in Latin "Vulpes," instead of "Fuchsius,' or an Englishman called "Woodcock" should be latinised into "Scolopáx." 
before his death; it was published 1616. Dodoens departed from the common plan of arranging the plants in alphabetical order, and attempted the bringing together of those which seemed in some way allied; and though his groups are sufficiently incongruous, he must be credited with having brought about some improrement in classification. This Herbal of Dodoens was a very popular one in England, as well as abroad, at the end of the sixteenth and the begimning of the seventeenth century. A translation of it into English by Henry Iyte, came out in 1578. There were different editions of it, one called 'Ram's Little Dodeon.'* Gerard's 'Herbal' is also founded on that of Dodoens.

Matthias Lobelius, or Lobel, or L'Obel, a Fleming, born at Lisle, in 1538, was a rery celebrated botanist. At the age of sixteen he evinced a great love for plants. $\mathrm{He}$ studied at Montpellier, and afterwards travelled over the south of France, Switzerland, the Tyrol, and parts of Germany and Italy; then he settled at Antwerp, and afterwards at Delft, practising as a physician. Subsequently he came to England, over which he made many explorations, and added many plants to our Flora; he superintended a physic garden at Hackney, and became physician to James I. Ifter publishing several learned botanical works, the chief being his 'Notes of Plants,' published first in 15\%0, he died in London, 1616.

Andreas Ceesalpinus, an Italian naturalist, was born at Arezzo in 1519, and died 160:3. He studied medicine, and took the degree of ductor. 'The botanical ideas of Casalpinus were more scientific than any of his time, and their intro.

* "Ram's Little Dorleon, out of the most exquisite new Herb:all, or History of Plants. first set forth in the Dutch Tongue by D. Reinbert Dodeon, and translated into English by Hemry Lyte, Lscquire, and abridgec by William Ram, Gentlenan." This is from a book catalogue; I have not seen it. 
duction in his work on plants did much for the advancement of a rational system of classification. He proposed a system of classification according to the nature of the flower, fruit, and seeds, thus initiating a new era in the Science. His herbarium is preserved in the Museum of Florence. The genus Crsalpinia was named in his honour by Plumier.

Fabius Columna, or Fabio Collonna, a learned Italian, was born at Naples about the year 1567, and died there 1650 ; he belonged to the ancient Roman family of the same name. Columna's accomplishments were very extensive; he was skilled in languages, mathematics, music, designing, painting, botany, \&c., and wrote treatises on many subjects. His 'History of Plants'* was published at Naples in 159:; and his 'Ecphrasis' (full account) was first published at Rome, 1606, and another edition appeared in 1616.

Joachim Camerarius was born at Nuremburg, 1534, and died there 1598 . He was a physician and botanist who in many ways forwarded his favourite Science. He founded a botanical garden at Nuremberg, for which he obtained many rare plants, and published a Herbal in German, at Frankfort, 1590. This really fine volume professes to be a translation of Matthiolus, but has all the merit of an original work; the illustrations are for the most part new, aud though artistically they are scarcely equal to the beautiful prints in Natthiolus, they have some advantages of their own. Thus separate pictures are given of the rarious flowers and fruits, both entire and dissected, which are absent from Matthiolus. Much of Matthiolus is also omitted in this work that has no connection with a Herbal, as, for instance, all the minerals and animals, with the solitary exception of the Civet, and why that is retained it is difficult to understand: much letterpress foreign to his object is also omitted by Camerarius, and fresh matter is introdnced.

* 'Phytobasanos, sive Plantarum aliquot Historia.' 
Our author treats of the medicinal uses of plants under two sections in each case: inwardly applied, and outwardly.

Prospero Alpini, or Prosper Alpinus, a physician of Padua, did good service to Botany by describing several fresh plants that he discovered in his travels. He was born at Marostica, in the north of Italy, 1553. As physician to the Venetian consul, Alpini visited Egypt, where he spent three years. He published worlss on exotic plants, on the balsam plant, and on rhubarb, and died 1617 at Padua, where he was at that time professor of Botany. Alpini's book on 'Exotic Plants' appeared in 1614, and a second edition by his son Alpini was published 1629." A number of the plants described are from the island of Candia, and the original author tells us that he had not only collected many plants himself, but had grown many from seed that liad been supplied to him by friends in different countries, including France and England. The genus Alpinia was named in his honour by Linneus.

We may now turn to our own country, and consider the work of a very genial and quaint-if not very eruditeEnglishman, John Gerard, and I hope to be excused if I dwell rather longer on him than I have on some much more learned men; not only because he was our countryman, but also because he was an excellent botanist, and wrote the most amusing and popular 'Herbal' that we have.

John Gerard, or as he is frequently called Gerarde, $\dagger$ was born at Nantwich, in Cheshire, in 1545 , and died in London,

* The edition by Alpini Alpini (also a physician) has the date 1627 appenderl to his "Address to the kind reader," but on the title page wo find " MDCXXVIIII."

$\dagger$ I lnow not why this essentially English writer should have a foreign appearance, and a false accent, given to his name by the ardition of a final $e$. It is spelt so in Jolnnson's entition (1633), on the title page, but in the original (or Gerard's own) he subscribes himself plain "John Gerard" to his declication to his patron, Lord Burleigh, and this is correctly adhered to in Johnson's edition. 
1607. He was educated as a surgeon, and practised in London, but is best known as a botanist. He superintended the management of Lord Burleigh's garden for twenty years, and had also a large physic garden* of his own, which he frequently alludes to in his 'Herbal,' and of which he published a catalogue. He became Master of the Apothecaries' Company. Gerard's 'Herbal' or 'General Historie of Plants' was published in 1597; it is a folio rolume of nearly 1400 pages, exclusive of introductory matter and indexes. It is founded on the work of Dodoens, of which indeed to a considerable extent it is a verbatim translation. Gray, in his 'British Plants' + writes as follows:- "Gerarde, although the Master of the Chirurgeons' Company, was not sufficiently versed in Latin to make this translation himself, and thereof altered a manuscript translation of one Dr. Priest, which the latter had intended to publish, but died before he had accomplished his purpose; and his papers falling into the hands of Gerarde, they were transposed from Dodonæus's arrangement of his subject into that of Lobell, and published by Gerarde without an acknowledgment of Dr. Priest's labour in the translation; indeed he speaks in his preface of Dr. Priest's translation having perished, although both Lobell and Johnson affirm that he used it himself with no other alteration than the above mentioned change of order in disposing the chapter's, and some additions. * * * Lobell was extremely angry at Gerarde having adopted his method, at which we may be surprised, since it undoubtedly may be considered at this time of day as an acknowledgment of his superiority over the order, if order it can be called, of Dodonseus; perhaps

* Gerard's was the first English physic garden.

+ 'A Natural Arrangement of British Plants,' by Samuel Frederick Gray, lecturer on Botany, the Nateria Meclica, and Pharmacentic Chemistry. London, 1821. 
Lobell's anger was that Gerarde's work, being in English, had a preferable sale to that of his own works in Latin, and might thus injure his purse, however the complaisance of Gerarde might flatter his self love." There would seem to be either some mistake in this accuunt or Lobel was a great hypocrite, else how can we account for finding amongst the introductory matter of the 'General Historie of Plants' a highly commendatory article by "Matthias de L'Obel to John Gerard greeting," in which our author is addressed as "Dearest friend Gerard." † To consider Gerard's 'Herbal' a mere translation of Dodoens, with Lobel's arrangement, would be a great mistake; as our author would probably express it 'They are no more alike than things that are most unlike.'

"There is a good and pleasant foode or bread made of the rootes of Parsneps as my friend master Plat hath set foorth in his booke of experimenes, which I have made no triall of, nor meane to do." That is Gerard's style of writing, a quaint, quiet humour, with abundance of local allusions; at one time to plants in his physic garden, at another to the remarkable effects he had found to be produced by some plant, then again how some of his friends at different times had found particular benefit from some remedy, or pointing out particular habitats for plants, gossiping, entertaining, and I think instructive throughout. As Gerard will be frequently quoted in the second part of this work, one other illustration shall suffice in this place. It is in relation to the "Vertues" of "Panax Coloni," or Clown's Woundwort (Stachys palustris of Limneus). " The leanes heerof stamped with Axungia, or Hogs grease, and applied rnto green wounds in maner of a pultis, doth heale them in such short time and in such absolute maner, that it is hard for any that

"Matthias de L'Obel Johnmi Gerarido felicitatem."

† "Gerarde amicissime." 
hath not had the experience thereof to beleeue: for being in Kent about a Pacient, it chanced that a very poore man in mowing of Peason did cut his leg with the Sieth, wherein he made a wound to the bones, and withal very large and wide, and also with great effusion of bloud, the poore man crept rnto this herbe which he brused in his hands, and tied a great quantitie of it vnto the wound with a peece of his shirt, which presently stanched the bleeding and ceased the pain, insomuch that the poore man presently went to his daies work againe and so did from daie to daie, without resting one day vntill he was perfectly hole, which was accomplished in a fewe daies by this herbe stamped with a little Hogs grease, and so laid upon in maner of a pultis, which did as it were glewe or soder the lips of the wounde togither, and heale it according to the first intention (as we tearme it) that is without drawing or bringing the wounde to suppuration or matter, which was fully performed in seaven daies, that woulde haue required fortie daies with Balsam itselfe. I sawe the wounde, and offered to heale the same for charitie, which he refused, saying, that I could not heale it so well as himselfe; a clownish answer I confesse without thankes for my good will, whereupon I haue named it Clounes Woundwoort as aforesaide," - a name it bears to this day. Gerard's 'Herbal' is divided into three books, the first "Containing Grasses, Rushes, Corne, Flags, Bulbose, or Onion-rooted Plants." The second book contains " the description, place, time, names, nature, and vertues of all sorts of herbs for meate, medicine, or sweete smelling rse, \&c. ;" and the third "the description, place, time, names, nature and vertues of 'I'rees, Shrubs, Bushes, Fruit-bearing plants, and other rare plants not remembered in the Proeme to the first booke. Also Mushroms, Corall, and their several kinds, \&e."

The work concludes with an extraordinary chapter on the "Goose tree," from which I make the following extract:- 
"Of the Goose tree, Barnakle tree, or the tree bearing Geese. Chap. 167."

"The Description.

"Hauing trauelled from the Grasses growing in the bottome of the fenny waters, the woods, and mountaines, euen vnto Libanus it selfe; and also the sea, and bowels of the same: we are arriued to the end of our Historie, thinking it not impertinent to the conclusion of the same, to end with one of the maruels of this land (we may say of the world). The Historie whereof to set foorth according to the woorthines and raritie thereof, woulde not onely require a large and peculiar volume, but also a deeper search into the bowels of nature, then my intended purpose wil suffer me to wade into, my insufficiencie also considered; leauing the historie thereof rough hewen, vnto some excellent men, learned in the secrets of nature, to be both fined and refined: in the meane space take it as it falleth out, the naked and bare truth, though vnpolished. There are founde in the north parts of Scotland and the Ilands adiacent, called Orchades certaine trees, whereon doe growe certaine shell fishes, of a white colour tending to russet; wherein are conteined little liuing creatures; which shels in time. of maturitie doe open, and out of them grow those little liuing things; which falling into the water, doe become foules, whom we call Barnakles, in the north of England Brant Geese, and in Lancashire tree Geese; but the other that do fall vpon the land, perish, and come to nothing: thus much by the writings of others, and also from the mouths of people of those parts, which may very well accord with truth.

"But what our cies haue seene, and hands haue touched, we shall declare. There is a small Ilande in Lancashire called the Pile of Foulders, wherein are found the broken peeces of old and brused ships, some whereof haue beene cast thither by shipwracke, and also the trunks or bodies 
with the branches of old and rotten trees, cast vp there likewise: whereon is found a certaine spume or froth, that in time breedeth vnto certaine shels, in shape like those of the muskle, but sharper pointed, and of a whitish colour; wherein is conteined a thing in forme like a lace of silke finely woun as. it were togither, of a whitish colour; one ende whereof is fastend vnto the inside of the shell, euen as the fish of Oisters and Muskles are; the other ende is made fast vnto the belly of a rude masse or lumpe, which in time commeth to the shape and forme of a Bird: when it is perfectly formed, the shel gapeth open, and the first thing that appeereth is the foresaid lace or string; next come the legs of the Birde hanging out; and as it groweth greater, it openeth the shell by degrees till at length it is all come foorth, and hangeth onely by the bill; in short space after it commeth to full maturitie, and falleth into the sea, where it gathereth feathers, and grorreth to a foule bigger than a Mallard, and lesser than a Goose; hauing black legs and bill or beake, and feathers black and white, spotted in such maner as is our Magge-Pie, called in some places a Pie-Annet, which the people of Lancashire call by no other name then a tree Goose; which place aforesaide, and all those parts adioning, do so much abound therewith, that one of the best is bought for three pence; for the truth heerof, if any doubt, may it please them to repaire rnto me, and I shall satisfie them by the testimonie of good witnesses."

We are afterwards told of these remarkable Barnakle trees that "They spamne as it were in March and Aprill; the Geese are formed in Mrie and Iune, and come to fulnesse of feathers.in the moneth after." *

* Jolnuson, in his eclition of Gerarl, remarks:- "The Barnakle whose fabulous breed my Author here sets downe, and diners others haue also delinered, were found by some Hollanders to hane another originall, and that by egs as other birds lane : for they in their third 
Clusius or Charles d'Ecluse was a Dutch botanist who was born at Arras, 1526, and died at Leyden, 1609. He travelled over various parts of Europe, and was for some time director of the Botanical Garden of Vienna. In 1593 he was professor of Botany at Leyden, and he was the author of several works. His 'History of Rare Plants' appeared in 1601 .

roiage to find out the North-East passage to China \& the Molucco's, about the 80 degree and eleuen minutes of Northerly latitude, found two little Islands, in one of which they found aboundance of these geese sitting vpon their eggs, of which they got one Goose, and tooke away sixty eggs \&e.". 


\section{CHAPTER V.}

\section{SEVENTEENTH CENTURY.}

The seventeenth century saw a further advance in botanical knowledge, and produced many illustrious writers on the Science. Among these the brothers John and Caspar Bauhin are pre-eminent at the commencement: they were natives of Basle.

John, a physician, was born 1541, and died 1613. He studied Botany at Tübingen, under Fuchs, and afterwards made the acquaintance of Gesner, with whom he travelled in Switzerland. He also collected plants in France and Italy. He was appointed professor of rhetoric in Basle in 1566, and in 1570 he was invited to be physician to the Duke of Wurtemberg, in which situation he continued until his death. He published several medical and botanical works; the most important did not appear during his life, but was published in 1650. This is his 'History of Plants,' which contains descriptions of about 5000 and is illustrated with 3577 figures.

Caspar Bauhin was born 1560, and died 1624. He studied first at the University of Basle, and afterwards at Padua, Montpellier, and Paris. In 1581 he took the degree of doctor of medicine, in 1582 he was appointed professor of Greek, and in 1588 professor of Anatomy and Botany in the University of Basle, where he afterwards also occupied 
the chair of practice of physic, and was made rector of the University and dean of the faculty. Of the several works that he wrote on medicine and Botany the most celebrated is his 'Table of the Theatre of Botany,'* which was published in 1623. It is an index to the works of the earlier botanists, in which are described nearly 6000 plants, with the various names given to them: it was the labour of forty years, and remains until now an invaluable collection of synonyms. Another large work planned by C. Bauhin he did not live to complete; it was called 'Botanical Theatre,' $\nmid$ and was to have been a history of all known plants, completed in twelve folio parts: three of these he finished, but one only was published. Plumier named the genus Bauhinia in honour of Caspar Bauhin; or perhaps after the two illustrious brothers, as the twin lobed leaves might suggest.

Though they may have little direct bearing on botanical nomenclature, we must not omit notice of two English botanists of this time, Johnson and Parkinson.

Thomas Johnson was born at Selby, in Yorkshire, and was brought up as an apothecary in London, where he kept a shop. In 1629 he published a "Journey into Kent in Search of Plants," and in 1632 an account of the plants growing on Hampstead Heath, which is the first of our 'Local Floras.' But his most important, or largest work, was a new edition of Gerard's 'Herbal,' published in 1633. Johnson became a soldier during the civil wars, having the rank of lieutenant-colonel on the royalist side, and he died of a gun-shot wound receired in a sally from Basinghouse, Hampshire.

John Parkinson, another apothecary, and contemporary with Johnson, published in 1629 an account of garden plants. In 1643 appeared his 'Theatre of Botany,' * 'Pinax Theatri Botanici.' ' Theatrum Botanicum.' 
describing 3800 plants. He died about 1650 , over 80 years of age.

I should not think it necessary to notice Culpeper, were it not that the 'English Physician' or 'Culpeper's Herbal' is, or was until quite recently, the most popular of handbooks with botanists of the operative class; therefore I feel bound not to pass him over.

Nicholas Culpeper was born in London, 1616, and was an astrologer, who referred the medicinal properties of all plants to planetary and stellar influences. 'The English Physician' was published 1652, and is, of the sort, a medical work. Like the 'Grete Herbal' it has passed through several editions, but certainly we cannot account for this as in the other case, by its being the only English work on the subject, and therefore of necessity the best. Culpeper's superstition is equalled by his wonderful self-conceit, which might only raise a smile, were it not that it frequently leads him to reflect offensively on the works of other and clearerheaded physicians. He thus addressed his wife, to whom he left his manuscripts :- " The works that I have published to the world (though envied by some illiterate physicians) have merited such just applause, that thou mayest be confident in proceeding to publish anything I leave thee, especially this master-piece; assuring my friends and countrymen, that they will receive as much benefit by this, as by my Dispensatory, and that incomparable piece, called Semiotica Uranica enlarged, and English Physician,"which is highly probable. Perhaps this self-exaltation is rather to be pitied than blamed, being a natural result of superstition, which may often be noticed in varying degree, when an easy faith oversteps reasonable bounds.* It

* Sir Walter Scott says in 'Guy Mannering':- " The belief in astrology was almost universal in the middle of the seventeenth 
cannot be said that Culpeper did anything to advance the science of Botany. He died in London, 1654.

About this time botanists were endeavouring to improve the hitherto very imperfect methods of classification, and greatest among these was our countryman John Ray, formerly spelt Wray, but altered by himself. A rather particular notice of Ray will not be irrelevant, for he was a careful student of the British Flora, and it is a pleasure to dwell upon the memory of this truly great and good man, who must ever be revered as one of England's greatest worthies, not only on account of his learning and the excellence of his writings, but also by reason of his uprightness and independence. As a botanist Haller terms him "the greatest in the memory of man," a commendation, considering him that applied it, which could in no way be exceeded in force. Ray was of humble origin, his father being a blacksmith, and during a long life he was never in what we

century; it began to waver and became doubtful towards the close of that period, and in the beginning of the eighteenth the art fell into general disrepute, and eren under general ridicule. Yet it still retained many partisans, even in the seats of learning. Grave and studious men were loth to relinquish the calculations which had early become the principal objects of their studies, and felt reluctant to descend from the predominating height to which a supposed insight into futurity, by the power of consulting abstract influences and conjunctions, had exalted them over the rest of mankind." It is curious, but I have an edition of Culpeper by one Dr. Parkins, of so late a date as 1810 , in which is abundance of such rubbish as this respecting the Bay Tree:- "It is a tree of the sun, and under the celestial sign Leo, and resisteth witcheraft very potently, as also all the evils old Satan can do to the body of man, and they are not a few ; for it is the speech of one, and I am mistaken if it were not Mizaldus, that neither witch nor devil, thunder nor lightening, will hurt a man in a place where a bay-tree is." I have planted bays ; they will do no harm, and answer better in cookery than Ancuba, Laurel, or Thododendron, which some cooks suppose to be all one thing. 
should call "good circumstances," though if he could have sacrificed something of his high sense of duty, his history will show that his ability might have led him to high preferment.

He was born at Black Notley, near Braintree, in Essex, 1628, and was sent when young to the Grammar School at Braintree, and when about sixteen to Cambridge. At twenty-one he was chosen junior fellow of Trinity, after acquiring the degree of B.A., and when he took the master's degree he became major senior fellow; at twenty-three he was chosen Greek lecturer of the college, at twenty-five mathematical lecturer, at twenty-seven humanity reader, at twenty-nine he was made prælector primarius, and at thirty junior dean. In 1660 he took orders in the English church; but refusing to subscribe the Act of Uniformity,.* in 1662, he was deprived of his fellowship, and lost all chance of preferment in the church. In 1667 he was elected a Fellow of the Royal Society.

* The Act of Uniformity "provided that every minister should, before the feast of St. Bartholomew (Aug. 24), publicly declare his assent and consent to everything contained in the book of Common Prayer, or lose his benefice. The appointed day came, and about two thousand ministers, the far greater part of them men of extensive learning, sincere piety, and irreproachable life, laid down their preferments, and, rather than do violence to their conscience, faced poverty and persecution."-Keightley's History of England.

"Among some miscellaneous observations of Mr. Ray's one is as follows:-September 18th, 1662. The names of such fellows of Colleges in the University of Cambridge, as were deprived for not subscribing according to the new Act for Uniformity, 1661: St. Jolnn's College, Mr. Wood and Mr. Tuckney; Trinity College, Mr. Wray; Emanuel College, Mr. Illingworth, Mr. Hulse and Mr. Brinsley; Pembroke Hall, Mr. Clifford and $\mathrm{M} \mathrm{r}$. Green; Bennett College, Mr. Chapman; Jesus College, Mrr. Huffe; Magdalen College, Mr. Hill and Mr. Mrore ; Ting's College, MIr. Duncombe; besides these, Dr. Dillingham, master of Emantul College."-Note from the original edition of Dr. Derham's life of Ray, published by Mr. Scott. 
Early in life Ray took great interest in Natural Science, especially in Botany, and after travelling over a great part of England, Scotland and Wales, he extended his herborisations to the continent of Europe. His itineraries, or accounts of his journeys in England, are most interesting." His works-chiefly in Latin, which he wrote with the same facility as English-were numerous and on different subjects. Of those on plants may be mentioned 'A Catalogue of Plants growing about Cambridge," 1660, and 'A Catalogue of English Plants,' 16r0. After these followed 'A Catalogue of Plants' observed in his travels; 'A new Method of Plants'; a 'History of Plants,' in three large folio volumes, enumerating and describing over 17,000 species; a 'Methodical Synopsis of British Plants'; 'An emended Method of Plants.' Besides these he wrote on quadrupeds and serpents, birds, fishes and insects, and also several religious works. Ray died 1706, at his native place, in the same humble condition as that in which he commenced life, leaving three daughters out of a family of four. Dr. Derham, who wrote a memorial of Ray, says:- "In a word, in his dealings no man more strictly just; in his conversation no man more humble, courteous, and affable; towards God no man more derout; and towards the poor and distressed no man more compassionate and charitable, according to his abilities."

As a systematic botanist Ray was in advance of his tine, and though his method was not duly appreciated in his life time, he must be looked upon as the founder of the modern or " natural" system of classification, as it is called.

Magnol and Tournefort in France, and Rivinus in Germany", each had his system of classification and his follower's.

Pierre Magnol was born at Montpellier, 1638, and died there

* See 'Memorials of John Ray,' by the late Dr. Lankester, purblished by the Ray Socicty, 18t6, or 'Temains of John Ray,' by Dr. Derham, 1760. 
1715. He was a botanist of great repute, and deservedly. It is after him that Plumier has named the genus Magnolia.

Joseph Pitton de Tournefort was born at Aix, in Provence, 1656 , and died at Paris, 1708. He was of a noble family, and was destined for the church, but his tastes leading him in the direction of Science, he became a botanist of considerable authority. He travelled over a great part of Europe, and also in Asia Minor, Armenia, the Caucasus, the neighbourhood of the Black Sea, dc., and made large collections of plants.

Augustus Quirinus Rivinus was born at Leipsic, 1652, and died 1725. He was a physician, and a professor of Anatomy and Botany. As I have before stated, it is not my purpose to explain the principles on which different botanists have founded their systems of classification, or to trace minutely the steps by which a universal system has at last been reached. Though the three last learned botanists each invented a system, these were all eclipsed by that of Linneus, which in its turn has been superseded by one founded on the principles first enunciated by Ray.

Plumier, whose name has already been frequently mentioned, was born 1646, at Marseilles, and died near Cadiz, 1704. He was appointed to explore the French settlements in the West Indies, and was afterwards sent to the Antilles; he resided some time in St. Domingo. Plumier's principal work, 'New Genera of Plants,' was published the year before his death.

Before taking leave of the seventeenth century a word may be said in honour of our "merry" but scapegrace*

* Rochester, at the request of the king, wrote his epitaph, which from its extreme pungency gave great offence :-

" Here lies our sovereign lord the King,

Whose word no man relies on;

Who never said a foolish thing,

And never did a wise one."

Perhaps the foundation of the Royal Society may be taken as that exception which is said to be necessary to prove a rule. 
monarch Charles II. He established the Royal Society, which, from his time to the present, has included amongst its fellows the most eminent scientific men of the Kingdom, and has been the means of great increase of knowledge. Ray has just been mentioned as a fellow, and one of the earliest was the gentle Evelyn, who contributed to its Transactions his celebrated "Silva," or "Discourse on Forest Trees:" 


\section{CHAPTER VI.}

\section{EIGHTEENTH CENTURY.}

\section{§ 1. Boerhaave, Haller, Dillenius.}

'T'here is very great variety in the botanical literature of the eighteenth century, and a great number of fresh plants from all parts of the world were discovered and described. It would occupy too much space to give more than a passing notice of a few of these writers, reserving the greater part of this chapter for Linneus, because, without instituting any comparison between him and other botanists who were his contemporaries, it is without doubt he who has the chief merit of inventing our present system of nomenciature, which is the subject we have principally in hand. I select these contemporaries of Linneus for previous mention: Boerhaave, Haller, and Dillenius.

Hermann Boerhaave, born at Voorhout, about two miles from Leyden, 1668, was one of the most celebrated physicians of the eighteenth century. He was carefully educated by his father, who intended him for the clerical profession, and he made such rapid progress in his studies that at eleven years of age he understood Greek and Latin. When sixteen years old Boerhaave lost his father, who left a family of nine children, in but poor circumstances. After much study, in which he greatly distinguished himself, in mathematics, philosophy and theology, he finally deroted himself to 
medicine, taking as his models Hippocrates and Sydenham. In 1693 he took the degree of doctor of medicine, at the University of Harderwyck, in Guelderland. In 1701 he was chosen lecturer on the institutes of medicine at Leyden ; and he commenced his duties by a discourse in favour of the study of Hippocrates. In 1714 he became Rector of the University. He was elected a member of the Academy of Sciences of Paris in 1728, and of the Royal Society of London in 1730.

He had great zeal for Botany, extended the botanical gardens at Leyden, and published many botanical memoirs. $\mathrm{He}$ acquired a considerable fortune, and resigned the chair of Botany and Chemistry in 1729. In his final address to his pupils he reverted to the doctrines of Hippocrates, and declared that man to be the first physician who knew how to wait for, and second, the efforts of Nature. Boerhaave died 1738 , at the age of sixty-nine. With all his learning he seems to have been a humble christian; Haller speaks of his venerable simplicity and his power of persuasion, and states that he has often heard him say, when speaking of the gospel precepts, that the Divine Teacher had shown in the Bible far more knowledge of the human heart than Socrates with all his wisdom.

Among his numerous works may be noticed the botanical ones-'Catalogue of Plants in the Leyden Garden,' and 'History of Plants.'

It would be impossible, in a short notice, to do justice to such a phenomenon as Haller. One of his biographers (Dr. Willis) describes him as "one of the most learned and indefatigable men the world has ever seen." We find in him an early erudition like that of Avicenna, combined with enormous intellectual power, diligently applied to original research.

Albrecht von Haller was born at Berne, in Switzerland, 
1708. From his earliest years his great talents became apparent, for with little or no effort he mastered the Latin, Greek, and Hebrew languages between his sixth and ninth year.* Even then he had assumed the habit of noting all the information that he considered interesting or valuable; so that while yet a lad he had the particulars of the lives of some thousand eminent persons written in his common-place book. In studying for the medical profession Haller went first to Tübingen, and afterwards to Leyden, where, among others, he had Boerhaave for a teacher. Among numerous other studies, Haller occupied some time with Botany, and in the Transactions of the Royal Society of Göttingen (under the patronage of our George II.) may be found some interesting and beautifully illustrated articles on some plants in their garden. As a physician, anatomist, physiologist, botanist, and poet, Haller will always be held in esteem. His biographer, already quoted, says: "It is impossible to deny that by his learning and assiduity, by the example of his life, and his teaching, and by the quickening influence of his theoretical views, he set his seal not only on his age, but has left it imprinted on all time." Haller died 1777.

Johann Jacob Dillen, or Dillenius, the first Professor of Botany at the University of Oxford, was born at Darmstadt, 1687, and studied at the University of Giessen. He became a very celebrated botanist; indeed, he wished to be considered the greatest of his time. In 1727 he published a Flora of Giessen; he adopted the system of Ray, in preference to those of Tournefort and Rivinus. Dillenius did good service to Botany by his study of the Cryptogamia, leading the way to a knowledge of their manner of

* It is open to anyone to doubt, or qualify according to his judgment such extraordinary statements; but it is not at all unusual to meet with instances where children acquire, as it were by intuition, what many could not gain in a lifetime. 
reproduction and development. Sherard was struck with the botanical merits of Dillenius, and invited him to England, where he remained for the rest of his life, supported by the patronage of the two Sherards.* He had the superintendence of Sherard's celebrated garden at Eltham, in Kent, and wrote a large folio catalogue, with illustrations and descriptions of the rare plants growing in it, called 'Hortus Elthamensis' (Eltham Garden). Dr. Sherard, dying 1728, bequeathed to the Oxford University a sum of money to endow a professorship of Botany, providing, at the same time that Dillenius should be the first occupant of the chair, thus placing him in a position of considerable eminence: he died at Oxford, 1747. Though without doubt an excellent botanist, the temper of Dillenius was not pleasant; it is generally called "peculiar," which may be freely rendered, somewhat jealous and unamiable. It is to be regretted that this infirmity should have led him to treat Linneus with little respect when the latter came to England, and should have caused our illustrious visitor to return home with a feeling of disappointment from our usually frank and hospitable country.

\section{\$2. Linneus.}

Carolus Linneus, or Carl von Linné, was born 1707, at Râshult, in Smaland, a province of Sweden. His father was a clergyman of small means, who was unable to assist him much in the prosecution of those studies to which he devoted himself. First he was intended for the church, and afterwards his father inclined to put him to some handicraft business, but was dissuaded from this by Rothman, the principal physician at Wexio, who took him into his house, and under whom he studied medicine for three years.

* See under "Sherardia," 2nd part. 
Afterwards he matriculated at the University of Lund; and in 1728 he went to the University of Upsal, where, obtaining a royal scholarship, he was enabled to pursue his studies without difficulty.

In 1731 Limneus was appointed to travel in Lapland under the royal authority, and at the expense of the University of Upsal. In this remarkable journey, which was one both of hardship and danger, Linneus travelled, mostly on foot, over about 3800 English miles. After this he was employed in various scientific work, his fame continually increasing. In 1736 he came over to England, but was disappointed with his risit, not gaining so much information as he expected; Dillenius too, professor of Botany at Oxford, though a very able man, was of a curious temper, and aspired to be thought the first botanist of his time, and he did not give Linneus a cordial reception. In 1738 Linneus settled in Stockholm as a physician, and from that time his fame and fortunes prospered apace. He was appointed successively botanist to the king, president of the Academy of Sciences of Stockholm, professor of medicine and then of Botany at Upsal; until, in 1757, he was raised to the nobility, assuming the title of Von Linné, by which he preferred to be known, and some writers* use this name in preference to Linnæus, which is of the two still more usual.

* Thus Willdenow, in his enlarged edition of 'Species of Plants,' and Jeffreys, in his beautiful work in 'British Conchology.' The latter writes :-" It was originally Linnæus; but on receiving the patent of nobility, he assumed the name of Linné. The latter name is giren in the twelfth (and most perfect) edition of the 'Systema Natur:e;' and in all his subsequent works and correspondence he always used this title of distinction. The learned Society which bears his name in this country is Linnean, and not Linnæan, as appears from their Charter and Transactions. Under these circumstances I hare adopted the name which he himself preferrect." Newwan also ('British Ferns') writes Limneus instead of Limmæus. I have followed in the same course. 
When raised to the nobility Linneus had become sufficiently wealthy to purchase an estate in the neighbourhood of Upsal. $\mathrm{He}$ was elected a member of all the learned societies of Europe, and many honours were conferred upon him for his scientific acquirements.

He died in 1777 , and his remains were deposited in a vault in the cathedral of Upsal. His obsequies were performed in the most respectful manner by the whole university, the pall being supported by sixteen doctors of medicine, all of whom had been his pupils. There was a general mourning at Upsal, and the king of Sweden caused a medal to be struck expressive of the public loss, and alluded to the subject in a speech from the throne. The system of classification invented by Linneus, together with the great improvement he made in botanical nomenclature, have served to greatly popularize the study of Botany; what was before chaos he brought into order, and what was before difficult he made easy. His system of classification, based on the number or position of the stamens and pistils, serves admirably to guide the learner to the name of a plant that he may wish to determine; though as a scientific arrangement of the vegetable kingdom it is worth nothing, plants being arranged side by side that have nothing in common beyond this trivial coincidence of two sets of organs. Thus in the class and order Triandria Monogynia (three stamens and one pistil) we find Valerian, Bryony, Butcher's Broom, Iris, Sedges; and these incongruities follow the system in a great measure throughout, though in a fer instances-as for example the class Tedradynamia, which is equivalent to the natural order Cruciferæ-this objection is not met with. But no general system of Botany could be permanently established, or be even temporarily satisfactory, which depends for its distinctions on one or two organs, or sets of organs only; and Linneus would seem to have been aware 
of it. Buffon says on this subject:- "This pretension of botanists to establish general systems, perfect and methodical, has then little foundation; and their labours have only availed to give us defective methods, which have been successively demolished the one by the other, and have suffered the usual fate of all systems founded on arbitrary principles; and that which has most contributed to the substituting of one of such methods for another, is the liberty that botanists have given themselves, to choose arbitrarily a single part of plants and to make of it a specific character: some establish their method on the shape of the leaves, others on their position, others on the form of the flowers, others on the number of their petals, and still others on the number of their stamens. If I should recal in detail all the methods that have been thought of I should never finish, but I shall only treat of those that have been received with favour, and have followed, each in its turn, without sufficient attention being paid to that error in principle which is common to them all, and which consists in trying to judge of a whole, or the combination of several wholes, by a single part, and by the comparison of the differences in this single part."

But notwithstanding the Linnean system has been superseded by a more scientific one, its study must be recommended to botanical tyros as a great assistance towards the mastery of the larger, and more perfect plan in many ways. The latter in its bare simplicity is so abstruse as to be quite incomprehensible to the beginner, and in order to guide him to the name of a plant which he may have found, artificial keys are made, which frequently turn out to be far more bewildering than the Linnean arrangement.

It is not, however, so much botanical classification that we are concerned with, as nomenclature, and this Linneus may be said to hare based on such sound principles that in 
all essential particulars his canons still remain a law to botanists. Nothing will better illustrate the principles of modern botanical nomenclature than these canons. They are as follow:-

1. The names of plants are of two kinds: those of the class and order, which are understood; and those of the genus and species, which are expressed. The name of the class and order never enter into the denominations of a plant.

2. All plants agreeing in genus are to have the same generic name.

3. All plants differing in genus are to have a distinct generic name.

4. Each generic name must be single.

5. Two different genera cannot be designated by the same name.

6. It is the business of those who distinguish new genera to name them.

7. Generic names derived from barbarous lang'uages ought on no account to be admitted.

8. Generic names compounded of two entire words are improper, and ought to be excluded. Thus Vitis-Idæa must give way to Vaccinium, and Crista-Galli to Rhinanthus.

9. Generic names formed of two Latin words are scarcely tolerable. Some of them have been admitted, such as Cornucopia, Rosmarinus, Sempervivum, \&c., but these examples are not to be imitated.

10. Generic names formed half of Latin and half of Greek are hybrid, and on no account to be admitted; such as Cardamindum, Chrysanthemindum, \&c.

11. Generic names compounded of the entire generic name of one plant, and a portion of that of another, are unworthy of Botany; Cannacorus, Lilionarcissus, Lauro. cerasus. 
12. A generic name, to which is prefixed one or more syllables, so as to alter its signification, and render it applicable to other plants is not admissible; as Bulbocastanum, Cynocrambe, Chamenerium.

13. Generic names ending in "oides" are to be rejected; as Agrimonoides, Asteroides, \&c.

14. Generic names formed of other generic names, with the addition of some final syllable, are disagreeable, as Acetosella, Balsamita, Rapistrum, \&c.

15. Generic names sounding alike lead to confusion.

16. No generic names can be admitted except such as are derived from either the Greek or Latin languages.

17. Generic names appertaining previously to Zoology, or other Sciences, are to be cancelled, if subsequently applied in Botany.

18. Generic names at variance with the characters of any of the species are bad.

19. Generic names the same as those of the class or order cannot be tolerated.

20. Adjective generic names are not so good as substantive ones, but may be admitted.

21. Generic names ought not to be misapplied to gaining the goodwill or favour of saints or persons celebrated in other Sciences; they are the only reward that the botanist can expect, and are intended for him alone.

22. Nevertheless, ancient poetical names of deities or of great promoters of the Science are worthy of being retained.

23. Generic names that express the essential character or habit of a plant are the best of all.

24. The ancient names of the classics are to be respected.

25. We have no right to alter an ancient generic name to one more modern, even though it may be for the better: this would in the first place be an endless labour, and in the next place would tend to inextricable confusion. 
26. If new generic names are wanted it must first be ascertained whether no one among the existing synonyms is applicable.

27. If an old genus is divided into several new ones the old name will remain with the species that is best known.

28. The termination and euphony of generic names are to be consulted as far as practicable.

29. Long, awkward, disagreeable names are to be avoided, as Calophyllodendron of Vaillant, Coriotragematodendros of Plukenet, and the like.

30. The names of classes and order's are subject to the same rules as those of genera. They ought always to express some essential and characteristic marks.

31. The names of both classes and orders must always consist of a single word, and not of sentences.

Lindley remarks of these canons* that they are undoubtedly excellent in many respects, that we must attribute much of the greater perfection of Natural History, since the time of Linneus, to the adoption of them, and that they are constantly appealed to by the school of Linneus as a standard of language from which no departure whatever is allowable. He continues:- "It is, however, necessary to remark, that notwithstanding the undoubted excellence of many of these rules, yet there are others adherence to which is often out of the question, and which have indeed fallen wholly into disuse. It seems to be an admitted principle that it is of little real importance what name an object bears, provided it serves to distinguish that object from everything else. This being so it will follow that Nos. 7, 9, $11,12,14$ and 16 of the Linnæan canons are either frivolous or unimportant, or at least that no person is bound, either in reason or by custom, to observe them. This is particularly apparent in considering the practice 
now universally adopted, although condemned by Linnæus, of converting the names by which plants are known in countries called barbarous into scientific generic names, by adding a Latin termination to them;" and he comes to this conclusion- "I agree with those who think a good wellsounding unmeaning name as good as any that can be contrived."

I shall not be alone in dissenting from this opinion, but its being held by such a high authority as Lindley will serve as a reason why many scientific names are mere gibberish, as far as lies in their possessing in themselves any comprehensible meaning. This does not apply so much to the nomenclature of the British Flora as to the Botany of the world.

The great excellence of Linneus' plan will perhaps appear more plainly by a comparison of his names with those of the most eminent botanists of his time. If we take up the 'Hortus Elthamensis,' of Dillenius, we find that the name generally consisted of three words, and these were frequently followed by about three more, of less importance, but still part of the name, thus:- " Bidens latifolia hirsutior semine angustiore radiato." This is the "Bidens pilosa " of Linneus; "Bidens Succisæfolio, radio amplo laciniato" of Dillenius, is "Coreopsis lanceolata" of Linneus. Again, if we refer to the synonyms in Willdenow's 'Species Plantarum' we find that Haller called "Helleborus fotidus," of Linneus, "Helleborus ramosus multiflorus, foliis multipartitis, serratis, stipulis ovato-lanceolatis, coloratis."

This was the kind of nomenclature which Rivinus did much to amend, but which Linneus put in its present form. Names without any meaning cannot generally be held as good as those which convey at least some smattering of information to impress them on the memory, if for no other reason. It might be said that the names of people applied 
to plants give us no information, but this is not exactly the case: "Sherardia" could not have received its name before the time of the Sherards, nor "Linncea" before the time of Limneus; so that these names at least gire us a scrap of information in botanical history.

Sir J. E. Smith took an entirely different view from Professor Lindley. He says:- "Botanists of the Linnean school, howerer, admit no such generic names from any other language than the Greek or Latin, all others being esteemed barbarous. Without this rule we should be orer. whelmed, not only with a torrent of uncouth and unmanageable words, but we should be puzzled where to fix our choice, as the same plant may have fifty different original denominations in different parts of the world, and we might happen to choose one by which it is least known." But even Smith, though a strong supporter of Linnean rule, admits some exceptions:- " Perhaps the barbarous name of some very local plants, when they cannot possibly have been known previously by any other, and when that name is harmonious and easily reconcilable to the Latin tongue, may be admitted, as that of the Japan shrub, Aucuba; but such a word as Ginkgo is intolerable."

As is usual in other cases, so it has happened in this; custom does not settle down to extreme riews, but takes a middle course. It would seem that where conrenience, or some other very good reason, justifies a deviation from the Linnean system, it would be least likely to lead to confusion if such cases were considered exceptions, and not fresh principles which should abrogate any of the Linnean canons. For after all naturalists unirersally concur in adopting this system of our authority, nothing better haring been invented. And these canons are the rules by which Linneus guided himself: ${ }^{*}$ they comprehend, in fact, the

* Being eridently rery methodical. Limnens was apparently in the 
system; and it would seem doubtful if there is anything more to be said in farour of these so-called barbarous names, than that from want of that lively and fanciful imagination which Linneus possessed so largely; or from the difficulty, if not impossibility, of finding some special botanical difference which should distinguish a genus from all others, and could be commodiously expressed by a Greek or Latin name, botanists have been forced to take the best course they knew.

I just mentioned the lirely imagination of Linneus; Sinith thus draws attention to some of his quaint fancies:- "Linneus in his entertaining book 'Critica Botanica' has in several instances drawn a fanciful analogy between botanists and their appropriate plants - thus, Bauhinia, after the two distinguished brothers John and Caspar Banhin, has a two-lobed or twin leaf. Scheuchzeria, a grassy alpine plant, commemorates the two Scheuchzers, one of whom excelled in the knowledge of alpine plants, the other in that of grasses.

"Dorstenia, with its obsolete flowers devoid of all beauty, alludes to the antiquated and uncouth book of Dorstenius.

"Hernandia, an American plant, the most beautiful of all trees in its foliage, but furnished with trifling blossoms, bears the name of a botanist highly faroured by fortune, and allowed an ample salary for the purpose of investigating the Natural History of the western world, but whose labours have not answered the expense," \&c.

This may be called scientific trifling, and Smith chuckles over instances where, coupled with a trivial name, such a plan has become offensive. "Buffonia tenuifolia," he says, "is well known to be a satire on the slender botanical pretensions of the great French zoologist, as the Hillia

laabit of first laying down the principles and rules by which he grided limself in his writings. We find a set of similar canons in the introduction to different works of his. 
parasitica of Jacquin, though perhaps not meant, is an equally just one upon our pompous Sir John Hill." Then he becomes sererely rirtuous, and exceeding fierce:- "I mean not to approre of such satires. They stain the purity of our lorely Science. If a botanist does not deserre commemoration, let him sink peacefully into oblivion. It savours of malignity to make his crown a crown of thorns, and if the application be unjust it is truly diabolical."

As to the naming of classes and orders there are no fixed rules that hare been attended to in the modern systegn, though Canons 30 and 31 might well apply; consequently there is no absolute uniformity. Lindles, in his great work 'The Tegetable Kinglom' (1846) adopts the uniform system of selecting one plant as the type of an order and adding acece to its name, but this plan has not been generally followed, and, howerer we may desire uniformity, it is open to some objection. If we apply the principles of Linnean rule, Canon $2: 3$ would lead us to think that Lindley has not improred upon the naming of Jussieu and others in many cases. Thus Cruciferie (bearing cross-shaped flowers or crucifers) mould seem better than Brassicaceæ* (the Cabbage family), because it expresses better the character of the order. Compositie (compound flowers) is superior to Asteracer (the Aster family); for in the case of common groundsel, and many other plants of the order, the ray which gives the star-like appearance is usually wanting. In the same way Leguminose (pod-bearing plants) is preferable to Fabacese (the Bean family), for though neither is perfect (as some Leguminosie bear drupes and not pods), the Bean only represents one sub-order of this extensire tribe (the Papilionaceæ, or butterfly-shaped flowers) out of three. Again, for similar reasons, I prefer Stellate (star plants, in reference to the whorls of leares) to Galiacer (Bedstraw

Lindley las Brassicacex, Crucifers, Asteracex, Composites! 
family), and Gramina (grasses) is more convenient and euphonious than Graminaceæ (grass family: see Canon 28).

We will consider now the second name which is given to plants. The first is called the substantive, or generic name, and the second the trivial, or specific name. It serves to point out the particular species of each genus, as generic mames make separate divisions of an order, and they are governed to a great extent by the rules already cited, but being of less consequence greater latitude is tolerated. As might be expected there is every shade of merit to be found in these names; they are good, bad, and indifferent. First, we apply the four corners of heaven-north, south, east and west, or borealis, australis, orientalis, and occidentalis; or the names of countries-as European, Asian, African, American, europæus, asiaticus, africanus, americanus; or the names of countries-as English, Welsh, Scotch, Irish, French, German, anglicus, cambricus, scoticus, hibernicus, gallicus, germanicus, \&c.; or still again in reference to particular places-as monensis, belonging to the Isle of Man; lancastriensis, to Lancaster; tunbridgensis, to Tunbridge Wells; cornubiensis, to Cornwall, \&c. As this class of names becomes more particular it becomes of less value, for it rarely happens that a plant is confined to one particular habitat.

Those names that point out a decided specific character are the best; as Arenaria trinervis (with three-nerved leares), Chlora perfoliata (stems perfoliate), Epipactis ensifolia (leares sword-shaped), grandiflora (large flowers), latifolia (broad leaves), sc. Then there are comparative names that are also good; as Sagittaria sagittifolia (arrowshaped leaves), Ranunculus hederaceus (ivy-like), Rubus corylifolius (hazel-leared). Next we have names that indicate some particular habit of a plant; as Scilla nutans (nodding, in allusion to the flowers), Potamogeton natans 
(floating, alluding to the leaves). There are other names, referring to the duration of the species; as Mercurialis peremnis (perennial), M. annua (annual) : and to the situations in which they grow; as Myosotis palustris (swamp), Vicia sepium (of hedges) : or the time of flowering; as Scilla verna (spring), Leucoium æstivum (summer); and in fact anything will serve for a good trivial name provided that it is correct, but generally those founded on the colous of the flowers are not good, because it is a variable feature, thus Digitalis purpurea (purple foxglove) has very commonly white flowers, and the gardeners' name of "Digitalis purpurea alba" shows the absurdities such names would lead us into. There are many similar cases : I will instance, in the British Flora, Viola lutea (yellow violet). Now, according to high authority, ${ }^{*}$ this species is not necessarily yellow. ${ }^{\prime}$ Then again Milkwort (Polygala vulgaris), though generally blue, we frequently find red, white, and blue, in the compass of a few yards, and to have called it cærulea would have been to give it a bad specific name.

The same may be said of Poor-man's Weatherglass (Anagallis arvensis), which is met both with pink and blue flowers, the two sorts being formerly called mas and fumina (male and female); we hare also Greek Valerian (Polmonium cæruleum), both white and blue; and the same with our common Blue-bell. So the colour of flowers must be taken as a bad specific distinction, and if, as in the case of Anagallis, specific distinctions are believed to exist, they should be founded on other characters than colour.

\section{* Bentham.}

t Though I have seen this plant growing in such profusion as to attract the attention of almost every passer by, as, for instance, between Chapel en-le-Frith and Castleton in the High Peak, and between Aberystwith and the Devil's Bridge, all yellow, I have frequently met with parti-coloured flower's that I could not refer to any other species. 
It is not unusual to apply the name of the first describer of a species as a specific name (spelt of course with a capital letter) in the possessive case, as Lepidium Smithii (Smith's Cress); while a personal name with an adjective termination is properly used as a specific name when it is complimentary only, as Carex Bœnninghauseniana, which is one of the longest botanical names I know. Such names are to be deprecated (see Canon 29) as uncouth and inconvenient, "and it is allowable to model them into grace as much as possible. I'hus the elegant Tournefort made Gundelia from Gundelscheimer, which induced me to choose Goodenia for my much honoured and valued friend Dr. Goodenough, now bishop of Carlisle, though it has when too late been suggested that Goodenovia might have been preferable" (Smith). This is in reference to generic names, but the same principle applies to specific ones.

The method of naming plants remains as it was left by Linneus, with the exception of such few and trifling variations from his rules as have been already pointed out. It will therefore not be necessary to pursue this sketch of the history of nomenclature further. Most of our British 'Floras' give the authority for every new generic and specific name since Linneus. An improved system of classification, on scientific and comprehensive principles, occupied for a long time the attention of botanists, and their labours have resulted in the now universally adopted "Natural System" * as it is called. Ray has been already mentioned as propounding the principles on which it is based. The most important Natural

$\therefore$ Though a convenient and usual term this is a misnomer, as is universally admitted, for all the systems of classification are artificial. It is not given to us to measure out creation,-we can but inclex it in an imperfect manner. 
Systems afterwards published are those of Jussieu, 1789; De Candolle, 1810 ; Endlicher, 1836 ; and Lindley, 1846.*

* A full account of these may be found in Lindley's 'Vegetable Kingdom.' The most approved method of learning the modern system is by means of schedules to be filled in by the student, invented by the late Professor Henslow, which is fully and clearly explained in Professor' Oliver's 'Lessons in Elementary Botany.' 


\section{CHAPTER VII.}

S U P P LE MENTARY.

Thougri I have thought it best not to prolong the foregoing sketch beyond Linneus, I hesitate to omit a short account of three illustrious botanists of our own country, who were contemporaries, were of world-wide repute, and who have not long since passed from us. I allude to Smith, Lindley, and Brown, placing them in that order because the two first have been so often mentioned in conjunction, or opposition, in the last chapter, as representatives of two systems, though chronologically Lindley should be placed last. A brief notice of these authorities is not impertinent to our subject, for they were all plant-namers of great experience, but as they are exceptions to my general plan I introduce them in a supplementary chapter.

James Edward Smith was born at Norwich, 1759, and received his first education at home. At eighteen years of age he turned his attention earnestly to Botany, and wishing to devote his life to medicine and natural science he went in 1781 to Edinburgh, to prosecute his studies. While there he was instrumental in forming a Society for the Study of Natural History, and was elected first president. In 1783 he went to London to study under John Hunter and Dr. Pitcairn, and was introduced to most of the best scientific 
society of that time. By the alvice of Sir Joseph Banks, , the well-known patron of naturalists, and with the assistance of his father, Smith purchased the collections of Linneus, which were then on sale, for nine humdred guineas. It was, however, only by a lucky chance that this valuable property was not lost to our country, for though, with the intention of combining the profession of medicine with lecturing on Natural History, Smith prevailed on his father to advance the purchase money, when Gustavus III. of Sweden, who had been absent in France, heard of the transaction, he sent a vessel to the Sound to intercept the ship which was conveying it; fortunately he was too late. In 1785 Smith was elected a Fellow of the Royal Society. In 1786 he travelled through Holland, France, Italy, and Switzerland, and in Holland obtained the degree of M.D. at Leyden. On returning to England, Botany soon occupied nearly the whole of his time. In conjunction with Sir Joseph Banks, Dr. Goodenough, and a few others, he founded the Linnean Society in 1788, of which he was first president, and retained the post for forty years. $\mathrm{He}$ delivered lectures on Zoology and Botany at his own house, and on Botany at Guy's Hospital. In 1814 he received the honour of knighthood from George IV., and died 1828.

* Sir Joseph Banks must be briefly noticed as the Mæcenas of his time (see Virgil, p. 5). He was of ancient family, and a great patron of naturalists. He was also a great traveller; he went with Captain Cook to observe the transit of Vemus in 1768, and in 1771 brought home numerous specimens of plants from Otaheite, Terra del Fuego, New Zealand, and Australia. He was for some time President of the Royal Society, and died 1820, at the age of 77 . Hc was not a writer of any great work, but contributed many valuable papers to several learned societies. As a patron of Botany, in which Ine especially took delight, Sir Joseph Banks must be credited with having done a great deal to forward the Science. He was exceedingly liberal, and his treasures were open to mon of seience at all times. 
The works of Sir James Edward Smith on Botany are very numerous and valuable. Among them may be mentioned his 'Introduction to Botany,' Grammar of Botany,' 'English Flora,' 'English Botany,' illustrated by Sorverby ("flippantly" as he complains, called 'Sowerby's Botany'), the botanical articles in Rees' 'Cyclopædia,' and a translation of Linneus' Lapland journal.

Smith was not only a learned and excellent botanist, but his writings are at the same time very interesting and amusing; they are not dry. Judging from his works one would say that he was naturally quick of apprehension, a close observer, and a man of great industry, but highly critical and combative, and sometimes rather peppery in his temper. Of course we might expect that Smith would be a great upholder of Linnean rule, as he became in youth the possessor of Linneus' treasures, and, as it were, continued his work, so that he was apt to hold too cheap the principles of a new and not yet fully accepted system for which he did not see the necessity. It must not, therefore, be judged that Sir J. E. Smith was not a good vegetable physiologist or systematic botanist; his works prove the contrary. I am inclined to think that we cannot yet with advantage put the Linnean sexual system completely on one side.*

John Lindley was an admirable botanist, who attempted an extension of the natural system of De Candolle, which, though it seems to possess great merit, has not taken much hold on the botanical world so far. He was born at Cotton, near Norwich, where his father had a nursery garden, and was educated at the Norwich Grammar School. We may say of this painstaking, accomplished, and industrious botanist, that his life was a pretty even-running career, and

* The Rer. Mrr. Henslow's plant schedules inclucle a statement of the Linnean class and order, and they are generally approred. 
leaves little for the pen of the biographer in the way of striking incident. The amount of work that he did was prodigious, and we shall be best enabled to appreciate the man by reference to his publications. Chief among them is 'The Vegetable Kingdom; or the Structure, Classification, and Uses of Plants, illustrated upon the Natural System,' 1846. It is a large work of over 900 pages, and is illustrated by upwards of 500 pictures, which are not only beautifully executed, but so well selected as to show the student almost at a glance the method of classification, by dissections which exhibit the peculiarities of particular parts or organs, as fruits, seeds, stamens, pistils, ovaries, or the arrangement of the floral whorls. Lindley divides the vegetable kingdom into seven classes; these again into fifty-six alliances, as he calls them; and these into 303 natural orders, which proceed from the simplest forms (Diatoms) to the most complex. Each order is described as to structure, an account is given of its distribution, and some of the most important and striking genera with their uses; and at the end of each chapter a list of the recorded genera, and the number, as near as may be, of species. Lindley is much to be admired for the clearness of his style, and for his excellent illustrations. He was not only a profound botanist, but a popular writer also ; and yet my experience of some of his professedly elementary works is that they do not completely answer their purpose; for I remember in a school of about thirty boys, which would give a fair average of intellect and enthusiasm, not one made any progress in Botany, though the class book was Lindley's 'School Botany;' an admirable work and very light reading to those who understand the subject beforehand.

We have just noticed the strong predilection of Smith for the Linnean system. Lindley was equally bigoted, or I will say enthusiastic, in favour of the natural system, and 
occasionally his enthusiasm carried him beyond all sustainable grounds, thus laying him open to much hostile criticism. For instance, it is not a proposition that can be maintained that plants falling into a certain natural order have in all cases the same or similar effects, if taken into the human stomach. Such a statement as the following in praise of the natural system is not only exaggerated but absurd:"Its advantage in applying Botany to useful purposes is immense, especially to medical men,* who depend so much upon the vegetable kingdom for their remedial agents. A knowledge of the properties of one plant enables the practitioner to judge scientifically of the qualities of other plants naturally allied to it, and therefore the physician acquainted with the natural system of Botany may direct his inquiries, when on foreign station, not empirically, but upon fixed principles, into the qualities of the medical plants, which have been provided in every region for the alleviation of the maladies peculiar to it. . . . Every one of these bears inscribed upon it the uses to which it may be applied, the dangers to be apprehended from it, or the virtues with which it has been endowed." Now supposing for a moment we glance over the order Leguminosæ

* Though formerly medical men were always botanists, this is not now even generally the case, beyond the knowledge necessary to an apothecary, nor excepting in rare circumstances would Botany be of any special service to them in their profession. I do not write as a medical man, neither did Lindley.

t This is a curious fancy, which would lead us to curious conclusions. Thus we might infer from it that the most sterile lands had the ferrest diseases, and vice versit, in regular gradation; or, that it is an error in principle for us in England to use such medicines as opium or quinine. If the statement is not a fact we might fancy another provision of Providence: that medicines, as well as many other things that we find of great use, are so distributed over the world as to oblige, or induce, the different members of the human family to help one another. 
(pod-bearing plants), which numbers at least 6500 species, we find the greatest diversity in qualities and effects. There is scarcely a purpose for which we use regetation to which this order does not contribute:-for fodder we have clover and retches; for human food peas and beans in great rariety; for ornament we tolerate in our gardens the laburnum, a deadly poison; among dye-stuffs we hare indigo, red saunders, \&c.; tanning materials, diri-divi, \&c.; gums, Arabic, tragacanth, \&c. ; medicine, senna,-and so on we might go for pages; for such differences may be found in most of the larger orders, and where there is great uniformity, as in the Crucifers and Mallows, it is rather a curious exception than a general rule. Of Lindley's other works may be mentioned the following:- 'Nonograph on Roses,' 1820, with drawings executed by himself, followed by works on several other special subjects. His 'Introduction to the Natural System' appeared in 1830, and afterwards 'Elements of Botany,' 'Figures of Plants,' 'Introduction to the Study and Physiology of Plants,' 'School Botany,' 'Medical Flora,' \&c. He devoted much attention to Orchids, and also made a study of fossil Botany, on which he wrote a work. Besides all this he was for many years editor of the 'Botanical Register,' and from its commencement edited the horticultural part of the 'Gardeners' Chronicle.' Further he was Professor of Botany in Unirersity College, London, from 1829 to 1860 , when he resigned; he was also lecturer on Botany at the Royal Institution, and at the Apothecaries' Garden, at Chelsea, was secretary of the Horticultural Society, and edited their 'Transactions' and 'Proceedings.' He was a Fellow of the Royal, Linnean, and Geological Societies.* He died in 1865 .

* In his 'Introduction to Botany,' 3rd ed., 1839, Lindley incidentally mentions his herbarium as containing 30,000 species; those who have collections of dried plants will understand how much labour this 
In Robert Brown we hare a botanist with whom it is a satisfaction to bring to a close the first part of this work. He was not only a great botanist, but a great traveller; he was not only of world-mide fame, but was one of that kind of men whose life seems to have a mysterious influence on the heart. Scratchy pens cease to spirt, and acrid ink becomes more kindly in writing of them, and so their memory is handed down from one to another; we cannot tell exactly how this is, though we might recall sereral instances. Such a one was Robert Brown.

To quote one of his biographers* he was "one of the most distinguished botanists that Britain erer produced." He was the son of a Scotch Episcopalian clergyman, and was born at Montrose, in 1\%テ3, was educated at Marischal College, Aberdeen, and aftermards studied at Edinburgh, attending the lectures of Dr. Putherford, Professor of Botany, in the University. After passing his examination at the College of Surgeons, he was appointed assistant surgeon and ensign to a regiment of Scotch fencibles,

implies. Many would think 1000 specimens in all was a fair collection; hear Lindley as to keeping specimens well arranged: - " Te constantly find botanists embarrassed by multitudes of unarranged specimens. As this is a great eril, I trust that a few hints may not be without their use; especially as by attending to them myself $\mathrm{I}$ hare probably not 500 unarranged specimens in a herbarium of more than 30,000 species." So 500 specimens was to him a mere bagatelle,-practically the same as having his drawer empty!

* Professor Balfour in 'Imperial Dictionary of Unirersal Biography.' This short sketch of the life and works of Robert Brown is chiefly taken from that source. There is a German translation of his works from 1825 to 1834, in fire rolumes, by Dr. C. G. Nees ron Esenbeck, in conjunction with some friends, the two first published in Leipsic, and the others at Xiirnberg. These include an account of his Australian discoreries, a Flora of New Holland and Tan Dieman's Land, and numerous other works. 
stationed in the north of Treland, where he remained until 1800 , prosecuting his botanical studies with great zeal and success. About this time he became acquainted with Sir Joseph Banks, by whom Brown was recommended as naturalist to the expedition sent out by the Government to explore the coasts of Australia, under Captain Matthew Flinders, in the ship 'Investigator'' 1801. . The vessel reached King George's Sound, on the south-west of Australia, 1802. Remaining there three weeks, he next visited Fort Jackson, and in July, 1802, the survey was continued to the northern and north-eastern shores, the gulf of Carpentaria, and the Pellew, Wellesley, and Wessel's islands. Then the ship went wrong, and the crew became sick, which caused an alteration of the plans, and the expedition returned to Port Jackson, arriving there June, 1803.

There had been great mortality among the crew, and the ship was condemned as unseaworthy, so Captain Flinders would return home. Brown and some others remained, and Captain Flinders intended to have returned, but suffering the double misfortune of shipwreck and imprisonment by the French governor of Mauritius, his plans became somewhat disarranged. Blown and the rest of the party remained until 1805, exploring the Blue Mountains, and other parts of New South Wales, as well as Tasmania and the islands in Bass' Straits.

As Captain Flinders did not arrive, Brown returned home, bringing with him a collection of 4000 species of plants. Shortly afterwards he became librarian to Sir Joseph Banks, and was subsequently appointed librarian of the Linnean Society. He was now in a position to give careful attention to his collection of plants, and published accounts both of them and of his journeyings; he also contributed a number of valuable papers to the 'Transactions' of the Linnean Society. 
In 1823 Brown came into possession of the library and herbarium of Sir Joseph Banks, who bequeathed them to him for his life. The collection of plants he offered to the British Museum, and he was appointed keeper of the botanical department in 1827, which post he occupied until his death.

In 1811 Brown became a Fellow of the Royal Society; in 1832 he received the degree of D.C.L. from the University of Oxford, and in 1833 he was elected one of the foreign associates of the French Academy of Sciences. In 1839 the Copley medal was awarded to him by the Royal Society for his researches on vegetable impregnation. In 1849 he was elected president of the Linnean Society, which office he resigned in 1853 . He received from Sir Robert Peel a pension of $£ 200$ a year for his scientific merits, and died in London, 1858.

"Brown was a botanist of the highest stamp. He possessed singular acumen, and was denominated by Humboldt 'botanicorum facile princeps'" (which may be freely rendered, the acknowledged chief of botanists). "All his writings display a wonderful power of botanical analysis, and an enlarged vierv of vegetable affinities. His name is known wherever Botany is cultivated as a Science, and his researches have promoted the advancement of Botany during the long period of nearly half a century. As a private friend he was loved, and respected. He was admired by a large circle of attached friends for the soundness of his judgment, the simplicity of his habits, and the kindness of his disposition."

So we may say in conclusion that though Great Britain was a laggard in Botany three hundred years ago, she has since amply made amends in all branches of its study. I only wish that space would permit me to make this still more apparent. 



\section{PART II.}

The Derivations and Meanings of the Scientific Nanies of Plants generally admitted into the British Flora as Natives or Colonists.

§1. SUBSTANTIVE NAMES.

§2. ADJECTIVE NAMES. 



\section{INTRODUCTION.}

Is the earlier part of this work it has been explained how the present system of nomenclature came about. Rivinus first hit upon the idea of having two names only, and Linneus brought this plan into complete order. We have now only two names for a plant; still in limited works, as local Floras and Monographs on particular genera, we frequently meet with a third name, as Athyrium Filixfœmina, var. plumosum, a form of Lady-fern, and such additions require a word of explanation.

It has been found impossible to fix precise limits for species, and so very careful study by different botanists has given rise to differences of opinion as to whether certain plants are distinct species from each other or not. It was long ago observed that under a specific name of Linneus were ranged a number of forms, which were often greatly different in some respects, and these forms were generally recorded under the Greek letters, $\alpha, \beta, \gamma, \delta$, sc. Some botanists have a tendency to see great importance in these differences of form, and would make several distinct species, while others think them of little consequence as specific distinctions, and reunite groups that have been separated. Thus Bentham ('Handbook of the British Flora') treats as forms, or varieties only of Primula veris, those three 
which have becn separated as species, P. veris, P. vulgaris, and P. elatior. Again some would divide Viola canina into V. sylvatica, V. flavicornis, V. lactea, dc., while other's would write under $\mathrm{V}$. canina:-These forms have been distinguished, $a$. sylvatica, $b$. flavicornis, $c$. lactea. These two schools have been jocularly called "lumpers" and "splitters" respectively. In most cases it has to be conceded to the painstaking "splitter" that he has distinguished what to all appearance are permanently distinct forms, though many distinguished theorists do not believe there is such a thing as a permanently distinct form in all creation. Without reference to these differences of opinion there remains the question whether it is expedient to multiply species beyond certain limits. If the same plan were adopted throughout the vegetable kingdom that has been worked out, or is still progressing, with the British Flora, in the course of a few hundred years-probably much sooner-Botany would become a mere ocean of words, and we should relapse into that chaos from which Linneus rescued us.

It frequently happens that on labels in gardens, conservatories, \&c., the word variety is omitted for convenience, but this need not mislead; thus we may see in a fern-house, Gymnogramma peruviana argyrophylla, where the last word is not a part of the name or of much botanical importance. The same applies to all cases where we find three names.

As generic distinctions are more important than specific ones, because they include the latter, so a generic name is considered more important than a specific one. We have seen from his canons how careful Linneus was to preserve old generic names, so far as was practicable. In order to do this to the greatest extent possible, he used an old single name given to the plant, when there was one, as a second or trivial name, where he found it necessary to place a plant 
under a newly distinguished genus. Of this we have many instances: thus Yellow-rattle was formerly called Cristagalli, but Linneus requiring a generic name for this and other species, and rejecting Crista-galli as unfit for his purpose (see Canon 8, p. 64) called the genus Rhinanthus, and this particular species Crista-galli. The same is the case with Achillea Millefolium, Aconitum Napellus, Adiantum Capillus-Veneris, Ranunculus Flammula, Spiræa UImaria, Teucrium Botrys, \&c.

In all these cases the second name is an old substantive name. It is commemorative, and not adjectival; we have two substantive names together, and in order to preserve the old name the more distinctly it is spelt with a capital letter, and retains its original termination irrespective of the other name with which it is joined; thus we say Galium Cruciata, Anthriscus Cerefolium, Polygonum Bistorta, \&c., in which the terminations do not agree as to gender. All these names are included in my first list, or that of substantive names.

Trivial names taken from the names of people (as explained p. 73) are spelt with a capital letter, while those derived from the names of continents, countries, or places, are generally spelt with a small letter, though by some with a capital. According to English usage we might think it the more correct plan to spell such like names with a capital letter, but as affecting the clearness of botanical nomenclature the small letter is preferable, and it was always used by Linneus. A capital letter to a trivial name loses something of its significance if it is applied in too many ways. In most cases when a plant is specified by the name of its habitat, this is expressed in the form of an adjective, as Euphorbia portlandica (Linneus), Portland Spurge; but sometimes the same object is attained by using a substantive in the possessive case, as Saccharum Teneriffæ (Willdenow), 
Sugar-cane of Teneriffe. In this case the second name is spelt with a capital letter. It is rather a nice distinction, for Willdenow has close beside the last-mentioned plant Saccharum benghalense, or Bengal Sugar-cane. The same principle applies to the names of plants. We do not write Tanacetifolium, Tansy-leaved, or Corylifolius, Hazel-leaved, as the form is adjectival, but we write Cuscuta Trifolii (Babington), Dodder of Clover, because Trifolii is a proper name in the possessive case.

After the explanations given as to the use of a capital letter for the second names of plants I do not think it is necessary to notice them further. If we meet with an old substantive name it should be found in my first list, and if it is the name of a person or a country it may be judged of by the termination. Where a trivial name is the same as an ordinary botanical term, I have pointed it out by repeating the word in its English form and explaining it.

It is unnecessary to encumber the text with the accidence of Greek and Latin, for it would be equally useless to anyone, whether he understood these languages or not. I have therefore taken no notice at all of the terminations. A few words of explanation will be sufficient.

The terminations of Latin adjectives may be taken generally to be governed in this way : masculine, us; feminine, $a$; neuter, um; - as acut-us, acut- $a$, acut-um, according to the substantive name with which it may happen to be joined. In other cases where the termination is is, it serves for the masculine and feminine genders, being changed to $e$ for the neuter, as gracilis, gracile. We have masculine niger (black), feminine, nigra, neuter, nigrum, but such instances are not common. Where they occur I have written them out in full. 


\section{Pronunciation of Scientific Names.}

It would be impossible to lay down absolute rules for the correct pronunciation of scientific names, and absurd to insist upon the accuracy of a certain pronunciation when another may be more usual. The Greek and Latin are dead languages, and each nation pronounces them according to the usage of its own language. We have good reason to suppose that the purest Latin spoken in our English fashion would have sounded exceedingly strange to an ancient Roman, and we are told by those who have studied the subject that we have no certain knowledge as to how these languages were pronounced. Their poets yield us valuable information as to the accentuation of words and the number of syllables, but even in this they are not certain guides. The Greek language guides us phonetically better than the Latin, because its alphabet contains a letter representing our short $e$ (as in pet), and another representing the long sound (as in peat); also it has a short $o$ (as in on), and a long $o$ (as in hone). It was also the custom to write Greek with marked accents. Rules have been laid down' in schools of learning, deduced from the critical examination of classical writings, but it is foreign to my purpose to dwell on them;-further, critical opinion on these subjects continually changes.

We must then fall back on usage, but even then we have this perplexity-What kind of usage? Suppose we examine the English language as spoken in Great Britain; the Englishman, the Scotchman, the Irishman, the Welshman, has each his own way of speaking it, and we may generally at once distinguish his province by his accent. And what is true of the greater divisions applies (though in a less degree) to nearly every county: thus the Lancashire dialect is all but incomprehensible to a native of the south of England, and can be even readily distinguished from that of 
Cheshire, Derbyshire, or Yorkshire. These differences are not confined to the working classes, for though they might be all equally learned, and use precisely the same terms and phrases, the pronunciation of an Englishman, Scotchman, or Irishman, each a graduate of a university of his own country, is very different, especially in the sound of the vowels. Such peculiarities of pronunciation need not, however, lead us into any confusion, for in the case of educated men the same method is followed uniformly in their whole discourse. I think, therefore, that we may safely adopt the usage of our universities, as exemplified by their graduates in all parts of the country, especially in our pulpits and law courts. It is true these learned men may know nothing of Botany, or have no occasion to pronounce botanical names, but, as I just stated, we in England pronounce Latin and Greek generally in the same way as we pronounce English, so that a correct pronunciation of the latter leads to, and is necessary for, the correct or usual pronunciation of scientific names. As to accentuation, it is usually marked in our British Floras as decided by botanists who are also classical scholars, and frequently university professors; if any one desires to pronounce these names in what would be considered the most correct manner by competent judges, it will have to be accomplished by observation of the usage of competent men, and study of the accents as set down in the books. There are still a few difficulties remaining, but they are not of great importance. Though in most cases our authorities agree, they sometimes differ, so that it is hard to see how we could by any means arrive at absolute uniformity: the difference of opinion to which I allude is met with, however, only in a few words, so few that they can easily be pointed out.

In many cases the discrepancies arise from a yielding up of what would appear to be the correct to the usual pronun- 
ciation. On the other hand, we often hear words pronounced in a manner which not only sounds odd, but for which there is no authority of any kind to be found, and which would be universally called incorrect by those qualified to judge. For instance, cotyl'edon instead of cotyle'don; umbil'icus instead of umbili'cus; Hydrocot'eel instead of Hydrocot'y-le; maritee'mum instead of marit'imum; ach'er instead of a'cre. A few illustrations may be given of the uncertain names: Cle'matis is correct, as being spelt in Greek with the long $e$, but Clem'atis is far more common, and has long been used,-it is therefore not incorrect; Clema'tis there is no authority for. Glad'iolus is correct; Gladi'olus is not uncommon, and (by usage) may be said to be not incorrect; Gladio'lus is a very common pronunciation, but I know of no book authority for it, and I should call it incorrect. Veroni'ca I believe to be correct, and it is the accent usually given in the books, but Veron'ica is much more common, and is adopted in the last edition of English Botany. Ar'butus is not uncommonly called Arbu'tus; Eri'ca, Er'ica; Enothe'ra, Enoth'era, and so we might go on. The reasons why we may in such like cases prefer a pronuuciation as the most correct, are easily illustrated. Thus in the case of Gladiolus the word is Latin, and a diminutive of gladius (a sword) in which the $a$ is short, and this with other diminutives, as Radiola, Corrigiola, is pronounced as first set down, according to undoubted rules of the language. In a word like Veronica I prefer the pronunciation Veroni'ca, - first, because it is that given by the older authorities; and secondly, because I accept the derivation Hiera Eicon (Holy image), which, if correct, decides the question of pronunciation at once. In placing the accents to the names I hare in doubtful cases consulted several authorities, and set down the different pronunciations that have any claim for notice, putting that which seemed to me best first, on the principles just explained. 
Passing by these doubtful instances, there are a few general rules that may be laid down to govern the great majority of cases.

It is well to keep continually in mind that we pronounce Latin in the same way as we should English, in giving the same value to the vowels. True, we are not at all consistent in our own language, talking as we do about iodine and chloreen, instead of chlorine; then we have maritime powers and a mercantile mareen, not marine. But anyone is most likely to be correct who uniformly pronounces the vowels of scientific words according to their ordinary English value: thus, vulga'ris, not vulgah'ris; marit'imum, not maritee'mum. If you must place the accent wrong, say mariti'mum. If this course is taken the pronunciation will be uniform, and not incorrect; and though the tendency at present is towards the continental system of pronunciation, any person who undertakes that method must be prepared to study the whole matter, that is to say, three or four languages,otherwise, to use a familar expression, he will "make a mess of it." The Greek $u$ is always changed into $y$; as polu, many, into poly. Then the Greeks had a letter called chi, which represented $c h$; and it has been disputed whether it should be pronounced gutturally, as in our word loch, or hard like lock. Some cannot pronounce the guttural if they try, and it is a matter of no great consequence.

As to the pronunciation of the two consonants $c$ and $g$, there is rather more difficulty. First, in respect to our letter $c$, which may be called a useless letter, possessing the sounds of others without having any peculiar to itself.* It has the sound of $s$, as in celery, and of $k$, as in cabbage; and it is often mute, as in science. In Keltic it is equivalent to $k$; the Cimri (Welsh) are Kimri, not Simri. In Greek

* The general rule is that in English or Latin $c$ has the sound of $k$, before $a, o, u$; and of $s$, before $e, i, y$. 
there is no such letter; but in passing through the Latin the Greek $k$ (kappa) is always changed into $c$ : kephalos, Greek, becomes cephalus, Latin. There is difference of opinion whether in such words $c$ should be pronounced soft, as sephalus, or hard, as kephalus; but I think the $s$ sound is most usual. In Greek words the $k(c)$ was always hard. I have always, in the following pages, changed the Greek $k$ into $c$. The difficulties of the letter $g$ are very similar. Those Greek words that come to us through the Latin, and have been long in use with us, generally follow English usage, and are pronounced soft, though not always: for instance, both gymnastic and jymnastic may be heard. In words direct from the Greek, especially modern scientific terms, as parthenogenesis, the $g$ is prounounced hard.

The following useful hints are taken from Withering's 'Systematic Arrangement of British Plants :'*-

"1. The English reader is desired to observe that the accent, or force of the voice, is be thrown on that syllable or letter which precedes the mark. Thus, in $A r^{\prime}$ butus, the $A r$ is to be the accented or strongly-sounded syliable, and not the $b u$, as is commonly, though erroneously, the case; and in Veroni'ca the $n i$ is to be the accented syllable, and not the ro, which is also a common error.

" 2 . That the letter $e$ at the end of a name is always to be sounded: thus the word Elat'ine is to be pronounced $E$-lat'-ti-ne, with four syllables, and not $E$-la-tine.

" 3 . That in words ending in ides the $i$ is always to be pronounced long.

" 4 . That $c h$ is to be pronounced hard, like the letter $k$.

" 5 . That in words beginning with sce and sci, the $c$ is to be pronounced soft; though it is allowed that some few words, derived from the Greek, are exceptions to this rule.

"6. That in such words as have sch, the $c$ is to be * Fourth edition, in four volumes, 1801. 
pronounced hard : thus Schœnus is to be pronounced as if it were Skémus.

" 7 . That $c$ and $g$ before $e$ and $i$, and before $e$ and $\propto$, are to be pronounced soft, but before the other diphthongs hard."

I take this exception to the last canon, that in Greek words the $g$ is always hard, as Geum, Potamogeton; not pronounced Jeum, Potamojeton.

A very slight attention to the marks and directions to be found in many botany books would lead anyone to a correct pronunciation of scientific names, yet it is not at all uncommon to hear good botanists pronouncing them incorrectly.

In the following list the generic names are arranged alphabetically, and old substantive names, now used to indicate particular species, are placed in an inner margin after the genus to which they are attached. The authorities for the names are given, so far as they have been noticed, in the former part of the book, but the others are omitted. The names of the authorities, since Linneus, are to be found in most Floras; and unless I gave an account of them they would be of no interest here. There are about fifty of these authorities who are namers of plants, which are included in the British Flora, that I have omitted, some of whom are still living. This, however, does not give a full idea of the extent to which an account of these authorities would stretch my proposed limits. I will give an illustration. If we turn to Epipogium in 'English Botany,' or other standard works, we find that the authority for the name is Gmelin. Now there were at least four Gmelins living about the same time. They died respectively-1755, 1768, 1774, and 1804. They were all of Tübingen, all travellers, all botanists, all authors; and it would be necessary in 
such cases, of which there are several, either to give some account of all of them, or to give such information as might mislead, on account of its incompleteness. Neither course would fall in with my intention.

\section{List of AbBReviations.}

I have made use of the following abbreviations only:G. for Greek; L. for Latin ; E. B. for 'English Botany' (3rd Ed., 1863-1872). 
LIST OF THE

\section{SUBSTANTIVE NAMES OF BRITISII PLANTS,}

Including those Specific ones ivhich are old Substantive Nanes, and are spelt with a Capital Letter; with their Derivation and Meaning.

A'cer, Pliny. L. for the maple tree; meaning sharp or hard. Ac, Keltic, in reference to the nature of the wood.

Pseu'do-plat'anus, Linneus.* G., pseud, false, and platanos, a plane tree.

Ac'eras, R. Brown. G., a without, and ceras, horn; because it is without nectary.

Acmille'A, Theophrastus; after Achilles, who is said to have first discovered that it healed wounds.

Millefo'lium, Tragus. L., mille, a thousand, and folium, a leaf; from the minute divisions of the leaf.

$I^{\prime} t a r^{\prime} m i c a$, Fuchs. G., causing to sneeze (sneezewort). Acurítur, Dioscorides; derivation doubtful. Some suppose from the town Acone, in Bithynia, near to which it was said to grow in great abundance; others because it was said to grow upon naked rocks, called aconce; and other's from alion, a dart, because used to poison such weapons.

Napel'lus, Dodonreus. Diminutive of L., napus, a turnip; referring to the form of its roots.

* The sycamore was called Platanus by Tragus. 
Ac'orus, Dioscorides. G., $a$, without, and core, the pupil of the eye; the diseases of which it was supposed to cure.

Cal'amus, Dioscorides. G. and L., a reed.

Aсте'A, Pliny. G., acte. A name originally assigned to the Elder, which the leaves of this plant resemble.

Actinocar'pus, R. Brown. G., actin, ray; and carpos, fruit, from its radiated fruit.

Damaso'nium, Pliny. Pliny says that the Alisma was. known to some persons as the Damasonion. It has also been applied to other plants: thus Gerard tells us that the names Alisma and Damasonium have both been used for Saponaria officinalis. The meaning is uncertain.

Adian'tun, Theophrastus. G., adiantos, dry; because water will not adhere to the fronds, so says Pliny; applied to Maiden-hair Ferns.

Capil'lus Ven'eris, Apuleius. L., capillus, hair, Veneris, of Venus. The Maiden-hair Fern.

Ado'srs, Matthiolus. After Adonis, who, according to heathen mythology, was the favourite of the goddess Venus. He was fond of hunting, and received a mortal bite from a wild boar which he had wounded; he was then changed into a flower.

$\operatorname{ADox}^{\prime} A$, Linneus. G., $a$, without, and doxa, glory; from its humble appearance.

Moschatellina, Cordus. Late L., muscus, musk; on account of its smell.

ÆGOPOD'IUn, or ÆGopo'DIUs, Linneus. From G., aig, goat, and pod, foot; its leaves being cleft something like a goat's foot.

Podagra'ria, Lobel. G., podagra, gout in the feet; because it was formerly supposed to cure gout. Goutweed, Herb-Gerard, or Goatweed, 
E'riu'sa, Linneus. G., aitho, I burn; on account of its acrid property.

Cyna'pium, Rivinus; from G., cyn, dog, and apion, parsley; dog's parsley. Fool's Parsley we call it. AG'raphis. G., a, not, and graph, write. The youth Hyacynthus was accidentally killed by Apollo, and was by him changed into a flower-the Hyacinth-the leaves of which bore in dark streaks the initials of his name; so runs the story. This similar plant (agraphis) having no such marks, has been also called Hyacinthus non-scriptus (L., non, not, and scriptus, written).

Agrmo'nia, Brunfels. Doubtful, said to be derived from G., argema, cataract of the eye, which this or some other plant was supposed to cure.

Eupato'rium, Dioscorides. From Eupator, king of Pontus.

The name has been given to a number of plants, of which he has been supposed to have discovered the uses.

Agrostemina, Linneus. G., agrou stemma, crown of the field; from its being an ornament to cornfields.

Githa'go, Tragus. From Gith of Pliny and the older botanists. Githago is mentioned by the botanists of the 16th century, and was applied as the specific name of this plant by Linneus.

Agros'tis, Theophrastus. G., agros, a field; a name given by the Greeks to different grasses.

Spi'ca-ven'ti, Lobel. L., spica, a spike, or ear (of corn), and venti, of wind; "by reason of his feather top, which is easily shaken with the wind."-Gerard.

AI'RA, Theophrastus. G., airo, I destroy; anciently applied to Lolium temulentum (Darnel), on account of its injurious effects, and now to this genus.

A $\mathrm{r}^{\prime} \mathrm{van}$, Pliny. Derivation uncertain; said by Pliny to be 
corrupted from abiga (abigo, to expel), of the Latins, a medicinal plant allied to this.

Chame'pitys. G., chamce, on the ground, and pitys, pine; Ground-pine. "Chamæpitys, called in Latin Abiga," Pliny.

Alchenim'la, Tragus; from Arabic alkêmelyeh, alchemy; on account of its pretended alchemical virtues. Théis.

Alis'sra, Pliny; a name that has been applied to different plants. Its derivation is said to be from the Keltic alis, water. It seems to have been most generally applied to species of Water Plantain.

Planta'go, Pliny; the L. name for plantain. The water plantain was formerly called Plantago aquatica; and next to it Gerard places land plantain, sea plantain, and "sea buckthorne plantaines." In modern classification these plants are widely separated, Alisma being monocotyledonous, and Plantago dicotyledonous.

Aluta'ria, Fuchs. L., Allium, Garlic; on account of the scent of the bruised leaves.

Al'́tiur, Plautus. L., Garlic.

Ampelopra'sum, Dioscorides. G., ampelo, vine, and prason, a leek. Dodonæus tells us that it grows spontaneously in vineyards, and hence its name.

Schœnopra'sum, Dodonæus. G., schœnos, a rush, and prason, a leek; from the rush-like form of the leaves.

Scorodopra'sum, Dioscorides. Name applied by Dioscorides to a kind of leek, and given by Linneus to this species.

Arroso'rus. From G., allos, various, and sorus, a heap; "the intention being no doubt to indicate the variation in the arrangement of the sori, occurring among 
the plants originally thought to belong to this family."-Moore.

Al'xus, Pliny. L., the Alder tree. The etymology has been referred to the Keltic and the Hebrew, but is uncertain.

Aropecu'rus, Theophrastus. G., alopec, a fox, and our'a, a tail, Foxtail.

Alsi'ne, Dioscorides. G., alsos, a grove; from its kind of habitat, according to Pliny. This name has been given to several quite different plants, but is now corfined to a genus of the Pink family, and the name of a sub-order Alsineæ is formed from it.

Althæ'A, Dioscorides. L., Marsh Mallow, from G., althein, to heal; from its healing properties.

Alys'sunr, Dioscorides. G., a, not, and lyssa, canine madness; a reputed remedy for this disease.

Amaran'tus, Pliny. From G., amarantos, unfading. Amaranth, Everlasting Flower.

Bli'tum, Dioscorides; old name for the wild Amaranth, or Blite. Pliny describes it as being "without flavour, or any pungency whatever; hence it is that in Menander we find husbands giving this name to their wives by way of reproach." In G., bletton, in L., blitum, from which is formed the adjective bliteus, signifying tasteless, insipid, silly, foolish, or stupid. Amsopríra. From G., ammos (the same as psammos), sand, and philos, loving. See Psamna. ANACH'ARIs. G., ana, without, and charis, elegance.

Alsinas'trum. Alsine-like, or like Chickweed, a name given by Professor Babington to a plant imported by some unknown means from America, first observed in 1842 , and now a very troublesome water weed.

Anagat'Lis, Dioscorides. The meaning is doubtful. The name has been used for several plants, as Pimpernel, 
or Poor Man's Weather Glass, Devil's Bit, and Brooklime.

Anchu'sa, Hippocrates. G., anchousa, alkanet, from ancho, I tie together, or constrict; on account of the medicinal powers attributed to it. It was considered good for ulcers, ringworm, lepra, measles, smallpox, and (properly compounded) was "most singular in deep punctures, or wounds made with thrusts," according to Gerard.

Andronr'EDA, Linneus. The name of a fabled daughter of Cepheus, king of Ethiopia; she was chained on a rock, that she might be devoured by a sea monster. Some resemblance of conditions was supposed by Linneus in the habitats of the Andromedas, which grew on "turfy hillocks in the midst of swamps frequented by toads, and other reptiles." This is rather fanciful, and characteristic of Linneus.

Anenione, or Anemo'ne, Dioscorides. From G., anemo, wind; because it was supposed that the flowers did not expand until beaten by the wind.

I'ulsatil'a, Dodonæus. From L., pulso, I beat; apparently having reference to the same idea as that mentioned under Anemone.

Axget'ICA, Brunfels. Church L., angelic ; from its cordial and medicinal properties.

ANTexia'ria. L., antenna, literally an extended thing; from the hairs of the pappus of the sterile florets resembling the antennæ of some insects.

As'rnenis, Turner. G., anthemis, a flower; from the profusion of its blossoms.

Cot'ula, Brunfels. Old officinal name C'otula foetida. Anтнохау'тним, Limneus. From G., antho, flower, and xanthos, yellow. 
An'nris'cus, Pliny. Derivation of the name unknown, but given by Pliny to a plant probably allied to this genus.

Cerefolium, Dodonæus. Old officinal name for Chervil. It is mentioned by Lonicerus, Camerarius, and other writers of that time. Linneus (Materia medica) gives it as the officinal equivalent for Scandix, and calls this plant (Sp. pl.) Scandix Cerefolium. It is a Latinised form of Charophyllum, which see.

Axthyl'Lis, Dioscorides. From G., anth, flower, and ioulos, down; from the downy calyces.

Antmrin' мux, Theophrastus. G. name referring to rhin, a nose; because of the shape of the flowers. One of the English names is Calf's-snout.

Oron'tium, Dodonæus. An old name for Snapdragon.

APAR'GIA. G. name for some uncertain weed which sprung up apo, from, argia, idleness (of the cultivator)!Hooker and Arnott.

A'prux, Pliny. L. for celery; from G., apion, parsley, water-parsley, \&c.

Aquile'gia, Tragus. From L., aquila, an eagle; whose claws the nectaries have been supposed to resemble.

Aríabis, Dioscorides. The Arabis of Dioscoricles was not one of our British Cresses.

Turrita, Clusius; who called this plant Turrita major. The name Turritis, which was also formerly used for this plant, was applied by Linneus to 'Turritis glabra, which see.

Ari'surus, Pliny. L. name for the Strawberry-tree.

Une'do, Pliny. Another L. name given to the same plant; because, according to Pliny, the fruit is so bad that $u n$, one (only), edo, I eat. 
Arc'trusr, Dioscorides: From G. arctos, a bear, on account of the coarse texture of the involucres.

Lap'pa, Virgil. L., the rending or tearing thing, hence a bur. Burdock.

Arctostaph'ylos, Adanson (see Cicexdia). From G. urctos, a bear, and staphyle, a bunch of grapes. Bear-berry. U'va-ur'si, Clusius. L., wva, a berry, ursi, bear's. Bearberry.

Arena'ria, Linneus. From L. arena, sand; the species growing most abundantly on sandy soils.

Aristoloch'ia, Dioscorides. G., Birthwort.

Clemati'tis. See Clematis, later.

ArMre'RIA. Said to be Latinised from French, armoires, and originally applied to various species of Dianthus. Gerard says, "The Sweet John, and also the Sweet William, are both comprehended under one title, that is to say Armeria, in French armoires; hereupon Ruellius nameth it Armerii flores." Thrift was called Statice Armeria by Linneus, and Armeria vulgaris by Willdenow.

ArMora'cia. A name formerly given to the Wild Radish (Raphanus Raphanistrum), and also to some of the Catchflies (Silene). Armoracia, Armoraria and Armeria appear to have been used indifferently in the last case. The origin of the name is not clear.

Arnos'eris. G., arnos, a lamb, and seris, chicory. Lamb's Chicory.

Arrhenath'erunr. G., arrhen, male, and ather, an awn; alluding to the structure of its florets, distinguishing it from Avena, which it otherwise much resembles. Artenir'sia, Hippocrates. From Artemis, the Diana of the Greeks, or from Artemisia, the wife of king Mausolus, who according to Pliny adopted this plant, formerly called "Parthenis," and gave it her name. 
Absinth'ium, Dioscoricles. G., apsinthion, L., absinthium. Name for Wormwood.

Arthrolo'biusi. G., from arthro, joint, and lob, pod; from the jointed seed-vessel.

$\mathrm{A}^{\prime}$ Runr, Dioscorides. G., aron; the meaning is uncertain. As'arun, Dioscorides. G., a, not, and sairo, I adorn;

because it was rejected from the garlands used by the ancients.

Aspar'agus, Dioscorides. L., from G. asparagos, from sparasso, I tear; some of the species being armed with spines; or perhaps more probably from aspairo,

I tremble, from the tremulous foliage.

Asperu'go, Pliny. From L., asper, rough.

Asper'ula, Dodonæus. From L., asper, rough.

C'ynan'chica. G., cynanche, quinsy, a reputed remedy for this complaint. Squinancywort.

Aspid'IUn. G., aspidion, a small shield; which its indusia resemble.

Fi'lix-mas, Fuchs. L., filix, a fern, and mas, male; the male fern.

Lonchi'tis, Dioscorides. From G., lonche, a lance; name given by Dioscorides both to the Holly Fern and the Hard Fern.

Oreop'teris. From G., oreo, mountain, and pteris, fern; the Mountain Fern.

Thelyp'teris. From G., thely, female, and pteris, a fern. 'The name Lady Fern is now applied to a different species. See Athrrium.

Aspuse'xiun, Dioscorides. G., asplenon; the name was given by Dioscorides to Ceterach, which he sets forth to be a remedy for diseases of the spleen ( $a$, privative, and splen, the spleen). See Ceterach.

Adian'tum-ni'grum, Lobel; the Black Maiden-hair (Spleenwort). See Adiantum. 
Fi'lix-fómina, Fuchs. L., filix, a fern, and fcemina, female; the Lady Fern. Formerly applied to Bracken (Pteris aquilina).

Ru'ta-mura'ria, Dodonæus. L., ruta, rue, and muraria, pertaining to walls; Wall Rue.

Trichom'anes. See Trichonianes, later.

As'ter, Linneus. G., aster, a star; from the form of the flowers. Dodonæus suggests the name of Aster marinus, but himself calls the plant Tripolium, after Dioscorides.

Tripo'lium, Dioscorides. G. name for the plant. Dios. corides said that this name was given because the colour of the flowers changes three times in a day; but this is not the case. Gerard argues that, though it is a fable that one flower changes three times in a day, three colour's may be found in different flowers at once, according to their state of development.

Astrag'alus, Dioscorides. G., astragalos, a cervical vertebra, or neck-bone. The exact application of this name is doubtful. It has been used for several plants, but for some time for the Mill Vetch.

Astran'tia, Linneus. From G., astron, a star; on account of the star-like umbels.

Athyr'iun. "The name of the genus was derived by Roth from the G., athyros, opened, or having an open entrance, alluding to the repressed indusium."Moore. The Lady Fern, which is also called Asplenium.

At'riplex, Pliny. G., a, not, and trephein, to nourish. The reason for the name is not clear.

At'ropa, Linneus. G., Atropos, one of the Fates, whose duty it was to cut the thread of life without any regard to sex, age, or quality; in allusion to the deadly qualities of thé plant. 
Belladon'na, Matthiolus; beautiful lady--a common name he says with the Venetians. It has been affirmed that the name was given because the Italian ladies were said to have employed it to give brilliancy to their eyes. It is a property of the plant to cause dilatation of the pupil of the eye. According to Théis, a water distilled from it was used in Italy to remove freckles from the skin.

Ave'Aa, Pliny. L., the oat; the derivation is unknown. Azs'Lea, Linneus. G., azaleos, parched, arid; because it is in such places that the plant grows.

Ballótт, Dioscorides. G., ballote, from ballo, I reject; on account of its disagreeable smell.

Barbare'a, Dodonæus. Dedicated to St. Barbara.

Bart'sta, Linneus. Named in honour of John Bartsch, a Dutch botanist and friend of Linneus. He died at the age of twenty-nine, at Surinam, in 1738, where he had been sent by Boerhaave and Limneus to examine the products of the country.

Odonti'tes, Pliny, who says that " a handful of the stems, boiled in astringent wine, is used for the cure of toothache." Hence probably the name (G., odont, tooth). This plant is supposed to be the same as the one mentioned by Pliny.

BEL'LIS, Fuchs. L., bellus, pretty.

Ber'beris, Brunfels. Berberys is the Arabic name of the fruit.

BE'TA, Pliny. L., beet; according to Fuchs, from the resemblance of the seed to the second letter (beta) of the Greek alphabet.

Beтоx'Ica, Pliny. Deriration uncertain. Pliny wrote:"The Vettones, a people of Spain, were the original discoverers of the plant known as the 'Vettonica' in 
Gaul" (the Betonica Alopecuros of Linneus, Foxtail Betony, a European species). Théis says that the name is altered from Bentonic, in Keltic; ben, meaning head, and ton, good, or tonic.

Bet'Ula, Pliny. L., a birch tree.

BI'Dexs, Linneus. L., bi, double, and dens, a tooth ; from the two teeth which crown the fruit.

Blech'num, Dioscorides. G., a fern.

Spi'cant. A name formerly given to the Hard Fern, but we have no satisfactory explanation of it. Bauhin attributes it to the Germans, and suggests that perhaps it is from Spica indica (Spikenard), on account of some resemblance. Linneus treated it as an old substantive name in writing Osmunda Spicant; but in his 'Species of Plants,' he gives the name Blechnum boreale. The name Spicant was re-applied by Roth, and, notwithstanding the unusual termination, it is generally accepted by botanists as correct, on the score of priority.

Buys'sus. From G., blysmos, a spring; because they grow in wet places.

Bora'Go, or Borra'Go,* Apuleius. From L., cor, the heart, and ago, I move. "Pliny calleth it Euphrosinum, because it maketh a man merrie and joyfull: which thing also the olde verse concerning Borago doth testifie :-

'Ego Borago gaudia semper ago.'

In English-

'I Borage bring alwaies courage.' "-

Gerard.

* A spelling used by many writers, and adopted by Dr. Hooker in 'The Student's Flora of the British Islands.' 
Borkhau'sta. Named in honour of Moritz Balthasar Borkhausen, a German botanist, who died at Darmstadt in 1806.

Botrych'iun. From G., botrys, a bunch of grapes; from the appearance of the branches of the fertile fronds. Luna'ria, Fuchs. From L., Iuna, the moon; on account of the crescent-shaped pinne of the barren fronds.

Brachypodiun, or po'diunr. From G., brachy, short, and podion, little foot; from the nearly sessile spikelets. Bras'sica, Pliny. L. for cabbage.

$\mathrm{Na}$ 'pus, Columella. L. for turnip.

Ra'pa, Pliny. L., Rapum, a turnip.

Bri'za. From G., brizo, I nod, or hang the head as in sleeping; name given in ancient times to some kind of corn.

Bro'sus, Theophrastus. G., bromos; the name given by the Greeks to the oat.

Bryo'sia, Dioscorides. From G., bryo, to shoot, or grow rapidly; on account of its quick growth.

Bu'niunr, Dioscorides. From G., bounos, a hill; referring to its favourite habitats.

Bupleu'rum, Hippocrates. From G., bou, an ox, and pleuron, a rib; in allusion to the ribbed leares of some species.

Bu'roxius, Theophrastus. From G., bou, ox, and temno, I cut; because the sharp leaves injure the mouths of cattle that browse upon them.

Bux'us, Pliny. L. for the Box Tree, from G., pyxos, name for the same plant; L., pyxis, a (box-wood) box, from the same root.

Caki'te, Serapion. An old Arabic name applied probably to this or some allied genus.

Calaniagros'tis, Adanson (see Cicendia). G., calam, reed, 
and agrostis, which see. Smith speaks of this as a "very faulty appellation," compounded as it is of two established names, contrary to Linnean rule (see. canon 11, p. 64).

Calanirs'tha, Dioscoricles. G., calaminthe; from cala, beautiful, or useful, and minthe, mint; on account of the great repute in which it was held as a remedy for many diseases.

Ac'inos, Dioscorides. G. name for Basil.

Clinopod'ium, or po'dium, Dioscorides. G., meaning bedfoot; "the tufts of which are like the knobs at the feet of a bed."

Nep'eta, Ne'peta, or Nepe'ta, Pliny. L., cat-mint; used for . this species of Calamint by Linneus.

Callit'riche, Pliny. G., cali, beautiful, and triche, hair; its stems being very long and slender, like hairs.

Callu'Na. From G., calluno, I cleanse or adorn. Smith says that "this name is doubly suitable, whether" we take it to express a cleansing property, brooms being made of Ling, or whether we adopt the more common sense of the word, to ornament or adorn, which is very applicable to the flowers." Bentham does not separate this genus from Erica.

CaL'THa, Pliny. From G., calathos, a cup, which its flowers resemble.

Calyste'Gia, R. Brown. Calos, beautiful, and stege, a covering; referring to the bracteas.

Soldanel'la, Dodonæus. Gerard called this plant Soldanella marina. Soldana and Soldanella were both common names for it with the apothecaries; but some writers called it Brassica marina, though, as Gerard remarks, "what reason hath mooued them so to do I cannot conceiue; *** of this I am sure, that this plant and Brassica are no more alike 
then things which are most unlike." Linneus called the plant Convolvulus Soldanella. The origin of the name Soldanella is by Pfeiffer referred to the Italian coin "soldo" by reason of its round leaves.

Canieli'na. From G., chamai, on the ground, and linon, flax. This does not seem a suitable name for the plant.

Campan'ula, Dodonæus. A little bell; diminutive of late L., campana, a church bell; from the shape of the flowers.

Rapun'culus, Lonicerus. A little turnip; diminutive of L., rapum, a turnip; on account of the shape of the root. Matthiolus arranges turnips thus:-Rapum rotundum (or round turnip), R. sylvestre (or wild turnip), R. longum (or long turnip), and Rapunculus (this plant, which we call Rampion); but the first three are Crucifers, and this last a Campanula.

Trache'lium, Gerard. Throatwort; from G., trachelos, a neck or throat; so called on account of the repute which it had as a remedy for inflammations of the throat.

CAN'NaBIS, Dioscorides. G. name for Hemp.

CAPSEL'LA. A little box or capsule; diminutive of L., capsa, a box; alluding to the seed-vessels.

Bur'sa-pasto'ris, Gerard; or Pera-pastoris of some old authors, as Lonicerus. From L., pera, a pouch, or purse, pastoris, of a shepherd; Shepherd's-purse. The word bursa would seem to be a Latinised form of French bourse, a purse or pouch. The French name is Bourse de Pasteur, or Shepherd's-purse.

Cardamíne, Dioscorides. From G., cardia, the heart, and damao, I overpower; from its supposed qualities.

Car'duus, Pliny. L., a thistle. Said to be from Keltic 
card, for combing wool; and this again from Keltic ard, a point: this is not certain.

Maria'mus, Linneus. The Carduus Marix of Fuchs, \&c., after the Virgin Mary. "In the days of monkish superstition the milky reins were said to have originated in the milk of the Virgin Mary having fallen on them as she nursed the infant Jesus; hence it was called the 'Holy Thistle' and 'Our Lady's Thistle:", -E. B.

CA'rex, Virgil. L. for sedge. 'The etymology of this word is uncertain.

Pseu'do-cy'perus, Dodonæus. G., pseud, false, and $C y$ perus (which see).

Carlína, Dodonæus. Same as Carolina (Carolus L. for Charles). "From a tradition that the root was shown by an angel to Charlemagne as a remedy for the plague which prevailed in his army." - Théis.

Carpi'nus, Pliny. Named from car, wood, and pin, a head in Keltic; the wood having been employed to make yokes for oxen. The English "Hornbeam" has the same signification.-Théis.

Bet'ulus, Gerard. L., Betula, a Birch tree. "It is also called Betulus, as if it were a lind of Birch." Gerard. The Hornbeam was formerly called either Betulus or Carpinus.

CA'run, Dioscorides. L. for caraway, from G. caros of Dioscorides, from Caria, where it grew. It was called Caros, Caron, Carum, Careum and Carui in the shops, according to the writers of the sixteenth century.

Bulbocas'tanum, Tournefort. From L., bulbo, bulb, and castanea, chestnut; the root having the flavour of a Chestnut.

Carui, or Carvi. See Carun. 
Castayia, or Casta'Nes, Pliny. L. for Chestnut; from Castania, a town in Thessaly that was famous for its Chestnut trees.

Catabro'sa. From G., catabrosis, a gnawing; from the erose extremities of the glumes.

CaU'calis, Hippocrates. G., from ceo, I lie down, and caulos, a stem.

Centau'rea, Pliny. From centaur, of heathen mythology, a being half man and half horse. "Centaury, it is said, effected a cure for Chiron, on the occasion when, while handling the arms of Hercules, his guest, he let one of the arrows fall upon his foot; hence it is that by some it is called "Chironion." "Pliny. This centaur Chiron was reported in Greek mythology to be famous for his linowledge of medicine, and to have taught mankind the uses of plants, especially medicinal herbs.

Calcit'rapa. "Name due to the resemblance of the calyx to the caltrops, or iron ball covered with spikes formerly used for throwing under the horses' feet to lame them on a field of battle."-E.B.

$C y^{\prime}$ anus, Pliny. G. name for this plant (which we call Blue-bottle), cyanos, meaning of a blue colour.

$J a^{\prime} c e a$, Clusius. The meaning is uncertain. The name was originally given to Heart's-ease; Centaurea Jacea was called Jacea nigra, to distinguish it.

Scabio'sa, Brunfels. L., rough, scurfy, scabby; but whether on account of the roughness of most of the plants to which the name was given, or of some sup. posed medicinal virtue, I know not. Gerard tells us, "It is reported that it cureth scabs." The name was formerly given to several thistle-heads.

Centranthi'us. From G. centr, a spur, and anthos, flower; Spur Valerian. 
Century'culus, Pliny. According to Théis, from cento, a patchwork; from the way in which it covers the ground.

Cephalanth'era. From G., cephale, a head, and anthera, anther.

Ceras'tium, Linneus. From G., ceras, a horn; on account of the rather long and curved capsules of some species.

Cenatophyl'́umi, Linneus. From G., cerato, horn, and phyllon, a leaf; from its forked leaves.

Céterach, Cordus. Scale Fern or rusty back. It has had many names, but was formerly generally called Asplenium (which see). It is said that Ceterach is derived from an Arabic name of this or some similar plant, but this is uncertain.

Chrnorhyz'Lum, Dioscorides. From G., chairo, I rejoice, and phyllon, a leaf. "It is thought to be called so because it delighteth to grow with many leaves; or rather in that it causeth joy and gladness."-Gerard from Dodonæus.

Cinamagros'tis. From G., chamai, on the ground, and agrostis, grass.

Chempanth'us, Linneus. “Kheyry. Arabic name of a plant with red and very sweet-scented flowers. It was embellished with the termination anthos to give it a Greek appearance. Then this Arabic word has a meaning in Greek from which Limné draws the etymology, cheir, hand, anthos, flower-hand-flower; that is to say, one which we carry in the hand on account of its fragrance."-Théis.

Chei'ri. See Ciremantius, above. The usual name for the Wallflower with the sixteenth-century botanists was Leucoium luteum; and Gerard (1597) calls it also Viola lutea. These names are given in Ray's 
'Synopsis' (1690), as also Keiri, and he gives as English names "Wall-flower or Wild Cheir."

Chelido'miun, Dioscorides. From G. chelidon, a swallow. The reason why this name was given to the plant is not very clear. Pliny says, "The brute animals have also been the discoverers of certain plants; among them we will name Chelidonia first of all. It is by the aid of this plant that the swallow restores the sight of the young birds in the nest, and even, as some people will have it, when the eyes have been plucked out;" and again, "These plants" (the greater and lesser Celandine) "blossom both of them at the arrival of the swallow and wither at the time of its departure." So far as I am aware, no other reason has been suggested for the application of this name.

Chenopod'iusi, or po'duus, Pliny. G., from chen, goose, and pod, foot-Goosefoot; from the shape of the leaves of some species.

Bo'nus Henri'cus, Fuchs. L. for good Henry. It appears to be a translation of the German name guter Heinrich. Fuchs includes Good Henry in his chapter on Lapathum, or Dock, of which he gives four kinds, this being the third. He praises it greatly as a vulnerary. The Germans have also the name böse Heinrich (wicked Henry) for Dog's Mercury.

Cherle'ria, Haller. In honour of John Henry Cherler, a friend and coadjutor of John Bauhin. He died at Montbeliard in 1610.

Cinlóna. From G. chloros, yellowish, or pale green; in reference probably to the flowers, which are yellow, or to the general appearance of the plant, which is remarkably glaucous, and produces a curious effect on the eye amongst the more dark green herbage. 
Chrysanth'enium, Dioscorides. G. from chrys, gold, and anthemon, a flower; from the golden colour of the flowers of some of the species.

Leucantliemum, Dioscorides. From G. leuc, white, and anthemon, a flower.

Chrrysosple'siuar, Tournefort. From G. chrysos, gold, and splen, the spleen ; on account of its reputed medicinal virtues.

CrCen'diA, Adanson. " A name of Adanson's, the etymology of which is nowhere explained; perhaps derived from (G.) Kikinnos, curled hair, on account of the slender, entangled stems and branches."-Hooker and Arnott. "We find the derivation of this genus of plants given from L. cis, and candeo, to burn within; thus we have cicindela, a glowworm."-E. B. (which, how ever, burns or glows on the outside). Adanson, a celebrated French botanist, published his work on the families of plants in 1763 . It seems strange that so able a man should give a name to a plant which, to all appearance, conveys no sense or meaning whatever. The meanings of many of his names are equally obscure.

Crcho'riun, Theophrastus. "G., cichorion; L., cichorium; chikouryeh in Arabic." We do not know the meaning of the name.

In'tybus, Pliny. Intubus, L. name for Endive or Succory.

Cicu'ta, Pliny. L. for Hemlock; given by Linneus to this genus.

CIr.C.' ${ }^{\prime}$, Dioscorides. Named from the enchantress Circe, a goddess of antiquity, who, it was said, by her knowledge of herbs and skill in their use, could procure love. The reason why the name was given to this plant is not clear. It was confounded with 
the Mandrake, which has long had such virtues attributed to it as those just alluded to, and the Circea is said to have been formerly used in the compounding of love philters. Gerard remarks of Circæa lutetiana: "There is no use of this herbe either in phisicke or chirurgerie that I can read of, which hath happened by the corruption of time, and the errour of some who have taken Mandragoras for Circea, in which errour they have still persisted unto this daie, attributing unto Circea the vertues of Mandragoras."

Cla'diux. From G., clados, a branch; perhaps from its many branches bearing spikelets.

Maris'cus. A name that has been given to different plants. Marisca, L. for a kind of Fig: a kind of Onion has also been called by this name, and Haller used it for the genus Schønus.

Chayto'nia, Linneus. Named in honour of John Clayton, one of the earliest American botanists, and a correspondent of Gronovius, to whom he contributed the specimens for the 'Flora Virginica,' which are now in the British Museum. He died in 1773.

Cléanatis, or Cleníatis, Dioscorides. From G. clema, a shoot of a vine; from its manner of growth.

Tital'ba, Dodonæus. From L. vit, vine, and alba, white. The name Vitis alba was formerly also used for Bryony (Bryonia dioica), hence called white or wild vine in some places.

CnI'cus, Tournefort. From G., cnizo, I prick or wound.

Cochlea'ria, Gesner. From L., cochlear, a spoon; on account of the shape of the leaves; in German, Löffelliraut. One of its old English names was Spoonwort. 
Colcir'rcunr, Dioscorides. From Colchis, where it was said to be first found and its virtues discovered.

Cons'arus, Theophrastus. G., comaros, a term applied by Theophrastus to some plants of the Arbutus tribe.

Co'miuni, Theophrastus. G. for Hemlock. See Cicuta.

Convalda'ria, Linneus. L., from convallis, a valley; referring to its usual locality.

Convol'vulus, Pliny. From L., convolvo, I entwine; just as we call the plant Bindweed

Soldanel'la. See under Calixstegra.

Corallorhíza, Haller. From G., corallion, coral, and rhiza, a root; from the form of the roots.

Conian'Drux, Theophrastus. From G., coris, a bug; on account of the foetid odour of the bruised leaves.

Con'xus, Pliny. L. name for the Cornel tree, and also for a javelin made of its wood.

Corrig'iola, or Corrigr'ola, Cordus. Diminutive of L., corrigia, a strap or thong; Strapwort.

Coryda'Lis, Galen. G. for the Fumitory. Dodonæus quotes Galen as the authority for the name.

Con'ylus, Pliny. G. and L. name for the Hazel tree. Avella'na, Pliny. According to Pliny from "Abellinum," in Campania, the district in which it was first produced. The place is now called Avellino, and Hazel nuts of a particular variety still abound there.

Cotoneas'ter, Bauhin. From L., cotoneum, the Quince. Cotrle'don, Dioscorides. From G., cotyle, a cup; from the form of the leaves. Besides our Navelwort, the name Cotyledon was formerly given to the Ivyleaved Toadflax (Linaria cymbalaria), the Marsh Pennywort Hydrocotyle vulgaris), and some other plants. See Cymbalaria, under Linaria.

Craníbe, Hippocrates. G. for Kale. 
Crate'Gus, Theophrastus. From G., cratos, strength; on account of the hardness of its wood.

Oxyacan'tha, Dioscorides. G. name which has been given to the Barberry, the Sweetbriar, and the Hawthorn by the older writers. The meaning of the word is oxy, sharp, and acantha, a thorn.

Cre'prs, Pliny. G., a name given by Pliny to some plant, from crepis, a sandal, which the leaves were supposed to resemble.

Crith'sum, Dioscorides. G., crithmon, it is said from crithe, barley; because the fruit of this plant is like a grain of barley.

Cro'cus, Theophrastus. From G., croce, a thread or filament; from the appearance of the saffron of shops, which consists of the dried stigmas of Crocus sativus.

Cryptogranima, R. Brown. From G., crypto, hidden, and gramme, a line; on account of the lines of fructification being hidden.

Cucubal'us, Pliny. The derivation has been given as an altered form of G., cacabolus, from caco, bad, and bole, a shoot, or sprig, meaning a noxious weed. Pliny's plant seems to have been the Black Nightshade.

Cuscu'TA, Matthiolus. Derived probably from its Arabic name Chasuth.

Epili'num. Growing on Flax. Not an old substantive name, though having the appearance of one.

Epithy'mum, Dioscorides. Growing on Thyme.

Crc'Lamen, Theophrastus. G., cyclamenos, from cyclos, a circle; probably on account of the spiral turns of the peduncles.

Cyn'odon. From G., cyn, dog, and odon, tooth.

Dac'tylon. G., a finger; on account of the fingered spikes. 
Cynoglos'sun, Dioscorides. From G. cyn, dog, and glossa, a tongue; from the form of the leaf.

Cynosu'rus, Linneus. From G. cyn, dog, and oura, tail;

from the shape of the spike.

Crpe'rus, Theophrastus. G., cypeiros, a reed.

Cypripe'diun, Linneus. From G. cypris, a surname of the goddess Venus, and poction, a sock, or slipper; Venus' slipper; as we say Lady's Slipper.

Cal'ccolus, Dodonæus. L., a slipper. Calceolus Marianus is the name given by Dodonæus. In mediæval times many plants originally dedicated to Venus were transferred to "Our Lady," or the Virgin Mary-e.g. (our) Lady's Mantle, (our) Lady's Slipper, \&c.

Cystop'teris. From G. cysto, bladder, and pteris, fern; on account of the hood-shaped cover of the sori.

DAC'TYLIS, Linneus. G., dactylos, a finger; from the form of the panicle.

Daph'Ne, Dioscorides. The name of a nymph who was changed by the gods into a Laurel or Bay-tree to save her from the pursuit of Apollo. Some of these plants have a resemblance to Laurels.

Lau'reola, Dodonæus. Diminutive of L., laun'us, a laurel; and given by the later Latin writers to this plant. The older name was Daphnoides-Daphne-like. Meze'reum, Linneus. Madzaryoun, its Persian name. Limneus, in his 'Materia Medica,' gives Mezereum as the officinal name for Daphne. Dodonæus quotes Avicenna and Serapion as using this name, but not for this plant.

Datu'ra, Linneus. Altered from its Arabic name tatorah (Forskal).* Rumphius says that in some parts of the

* A Sweclish naturalist of the last century, who was employed by the king of Demmark on a scientific expecition to Egypt and Arabia. 
East Indies it is called daturo. Linneus gives Datura as both the officinal and the botanical name of Thorn-apple ('Materia Medica'). Camerarius gives Tatula as the name of his second species of "Stramonia."

Strano'nium, Lobel. The name Stramonia was generally given to the Thorn-apple by the botanists of the sixteenth century, and Lonicerus says that it was so named by the Italians. The derivation is obscure.

DAU'cus, Dioscorides. G. name for the plant. "From daio, I burn; on account of its effect in medicine. All the ancient authors speak of daucus, as a heating plant."-Théis.

Carot' $a$, Linneus. Carrot is the English name, and carotte the French. Carotte is also used in German, but is not the usual name. It has been supposed to be of Keltic origin, and to refer to the colour of the root; car, red.

Demphin'tum, Dioscorides. From G. delphin, a dolphin; on account of the form of the flower. The Delphinium of Dioscorides was not the Delphinium of Linneus, but the name was used by him.

Consol'ida, Fuchs. A name given formerly to Larkspur, and also to Comfrey, Self-heal, Daisy and other plants, in reference to some real or supposed virtue in the healing of wounds. The L. verb consolido means I make solid, firm or compact. See Solidago.

Denta'sia, Linneus. From L. dens, a tooth; from the tooth-like scales of the root.

Diantu'us, Linneus. From G. Di, Jove's, and anthos, flower.

Arme'ria, Linneus. A name formerly given to the Sweet William pinks. See earlier under Arireria. Caryophyl'lus, Linneus. From G. Caryophyllon, the spice 
which we call clove. The above tree was formerly called Caryophyllus; the clove gilliflower, or pink, Caryophyllus multiplex; and Avens, or Herb Bennet, was called Caryophillata; the last on account of the smell of the roots, and this plant from the smell of the flowers being like cloves.

Digita'Lis, Gesner. From L. digitale, a glove; as we say Fox-glove, from the flower being like the finger of a glove.

Digita'ria, Haller. From L. digitus, a finger.

Dígraphis or Dig'raphis. From G. di, two, and graphis, a style.

Dro'ris. G., di, two, and otis, eared; from the ear-like appendages to the fruit.

Diplotax'is. From G. diplo, double, and taxis, order or arrangement; in allusion to the two rows of seeds.

Dip'sacus, Dioscorides. From G. dipsao, I am thirsty; the connate leaves forming a kind of cistern in which water is retained.

Doron'icun, Brunfels. "Named from (G.) doron; a gift, and nice, victory; because it is said to have been formerly used to destroy wild beasts, whence the English name of Leopard's-bane; or some say from doronigi, or durungi, the Arabic name of the Leopard's-bane, Latinised by earlier botanists into doronicum, and enumerated by Linneus among barbarous names which ought to be rejected. $\mathrm{He}$, however, retained it, perhaps because its sound, if not its sense, is Greek."-Hooker and Arnott.

Pardatianch'es, Linneus. G., pardali, panther, and anch, strangle; or Leopard's-bane.

Dros'era, Cordus. G., dros, dew. This plant is not mentioned by the ancients, but it was called L., Ros (derv) solis (of the sun) by the apothecaries of the 
middle ages; referring to the viscid drops which exude from the leaves, and present an appearance resembling dew.

Dry'As, Limneus. From G. drys, oak; on account of some resemblance in the leaves. Clusius calls it Chamædrys montana.

Echirochlo'A. G., echino, hedgehog, and chloe, grass.

Echinoph'ora, Columna. G., echino, hedgehog, and phora, bearing - as one wears clothes; referring to the prickly nature of the plant.

E'chrum, Dioscorides. G., echi, viper; because it was supposed to be a protection, from, and a cure for, the bite of a viper. Gerard says of this plant:"The roote drunke with wine is good for those that be bitten with serpents, and it keepeth such from being: stung as haue drunke of it before; the leames and seedes do the same, as Dioscorides writeth: Nicander, in his booke of Treacles, maketh viper's Buglosse to be one of those plants, which cure the biting of serpents, and especially of the viper, and that driue serpents away."

Erat'ine, Dioscorides. G. name applied to some plant growing among corn. It is not known with certainty to which, and we have no satisfactory explanation of the reason for its application. Matthiolus represents it to be the sharp-pointed Fluellen (Linaria Elatine). IIydropi'per, Dioscorides. G., hydro, water, and peperi, pepper; Hydropeperi. The slightly altered form Hydropiper is given by Fuchs, Matthiolus, \&c. Eleoch'Aris, R. Brown. G., heleo, marsh, and chair, to delight in; from the situations in which it grows. It would be more correctly spelt Heleocharis.

Elo'dea. G., helo, a marsh. See Eleocharis. 
Er'ynus, Dioscorides. Name given by the Greeks to Panicgrass.

En'Petrun, Dioscorides. G., en, in, and petro, rock; growing in rocky plàces.

Epilo'biun, Gesner. G., epi, upon, and lob, pod; from the flower growing upon the pod-like ovary.

Eprne'diun, Dioscorides. “Analogous to medium, a plant which was supposed to grow only in Media, from which it obtained its name. See Dios. b. 4, c. 18. He speaks of Epimedium next after Medium."-Théis.

Epipac'tis, Dioscorides. A name given by the Greeks to some sort of Hellebore. It was applied by Haller to this genus of Orchids. Derivation doubtful.

Epipo'gius, or Epipo'gunr. "From G. epi, upon (or uppermost), and pogon, a beard; an appellation given by Gmelin," because the lip (called by him the beard) is uppermost."-Hooker and Arnott.

Equise'tun, Pliny. L., equi, horse, and setum, hair' horsetail, as we say.

Telmatei'a. G., pertaining to a marsh or swamp.

Eran'this. G., er, spring, and anthis, flower.

ERI'CA, Dioscorides. G., ereice. The derivation is said to be from ereico, I break; because it was formerly supposed to have the power of destroying calculi of the bladder. Yet the old botanists give but little prominence to this supposed property. Matthiolus mentions it, but from Dioscorides downwards the chief virtue ascribed to the genus is as an application to the bites of snakes. It puzzles me where they got so many snakes in Europe, especially in England, for we have only one venomous kind, and its bite is seldom a very serious affair.

Enig'enox, Theophrastus. From G., eri, early, and geron, an * A German botanist of the last century. 
old man, or grey-head; in allusion to the receptacle, which soon becomes like a grey head.

Eriocat'lox, Gronorius. G., erio, wool, and cuulon, stem; in allusion to the dorny stems of the species first known.

Erioph'orux, Theophrastus. G., erio, wool, and phor, bear; bearing wool, cotton-sedge.

ERo'DIuxr. G., erod, heron; from the beaked fruit, as we say Heron's-bill.

Enyag' Itri, Dioscorides. "Eryngion in Greek; derived from erygein, a word which means the act of eructation. Dioscorides states positively that Eryngium dissipates all windiness."-Théis.

ERys'rnus, Theophrastus. G., derived from eryo, to draw (blisters).

Ertthre's. G., erythr, red; the colour of the flower.

Centau'reum, Dioscorides. See earlier, under Cextaurea.

This plant is the Centaureum minus of Fuchs, Centaureum parvum of Gerard. In Lancashire and Cheshire it is not uncommonly called Sanctuary, which is a corruption of the name Centaury.

Evox'ynus, Theophrastus. G. name for the plant; from Euonyme, mother of the Furies, the berries being poisonous.

Ecpato'riuni, Dioscorides. See earlier, under Agrimonia, which was Eupatorium of Matthiolus; this plant (Hemp Agrimony) being his Eupatorium rulgare. EupHor'BLA, Dioscorides. This word means, literally, plenty of food, and seems a strange name to apply to a genus of plants which are, for the most part, poisonous; unless indeed on the principle that a little of it goes a long way. The derivation, we are told, is from Euphorbus, physician to Juba, king of Mauritania, who is said to have brought the plant into use. 
Cyparis'sias, Dioscorides. From G., cyparissos, the cypress; on account of its similar foliage. This plant was called by Matthiolus, \&c., Tithymalus Cyparissias.

$E^{\prime}$ sula, Dodonæus, who gives this ingenious conjecture as the explanation of the word:- " The name Esula may be derired from (G.) pityusa,"-like the Pine-tree (pitys) in foliage; a name then usually given by scientific men to the plant,- " for, lay aside the first two syllables (!) and usc remains, of which the diminutive is usula; change the first rowel, and you have Esula." This looks at first rather a far-fetched derivation; but Esula was the officinal name of the plant, and the apothecaries before and about this time performed such remarkable feats in the way of corrupting names that it is quite possible that Dodonæus is right.

Heliosco'pia, Dioscorides. G., helio, sun, and scop, watcher; because the flowers face the sun.

Lath'yris, Dioscorides. G. name for the plant.

Para'lias, Dioscorides. G., paralias, growing on the coast. Pep'lis, Dioscorides (see later). So called on account of the foliage somewhat resembling that of Purslane.

Pep'lus, Dioscorides. G., peplos; name for a kind of Spurge.

We may remark the unusual number of substantive names for Spurges, which shows the estimation in which they were held. Gerard describes twenty-one kinds.

Euphra'sia, Fuchs. G. for gladness. The plant was formerly called Euphrosyne, meaning also gladness. The plant was so called on account of its reputation for clearing the eyes. Fuchs complains that the name is corrupted by "ignorant druggists" from 
Euphrosyne. Other names which were, and some of them still are, used for this plant, refer to this remedial property as Ophthalmica and Ocularia; in French, Euphraise ; in German, Augentrost; and in English, Eyebright.

FA'Gus, Pliny. L. for the Beech-tree, from G. phegos; though the G. phegos was not the Beech, but a kind of Oak; so there has been some confusion. "But here I may not omit a note of the accurate critic Palmerius, upon a passage in Theophrastus, where he animadverts upon his interpreter, and shows that the ancient phegos was by no means the Beech, but a kind of Oak."-Evelyn's 'Silva.' White, in his 'Latin Dictionary,' gives Fagus (a Beech-tree) as equivalent to G. phegos; but Liddell and Scott (Greek Dictionary) give us-Phegos, "a kind of Oak bearing an esculent acorn, not the Latin Fagus (Beech)." The name is evidently the same, but some confusion has arisen in its application.

FE'DIA, Adanson (see CICENdiA). A name without any known or probable meaning.

Auricula. L., an ear.

Festu'ca, Dodonæus. L., "from fest, Celtic, food or pasturage."-Hooker and Arnott. L. festuca means a stalk, stem, or straw.

FilA'Go, Dodonæus. L., fil, thread; the plant being covered with thread-like hairs.

Fenic'ulum, Pliny. Fœn, hay; the smell of the plant being likened to that of hay.

FraGa'RIA, Pliny. L. for the Strawberry. "Fraga (akin to Sanscrit root ghra, odorari), the fragrant things; hence Strawberries." - White's Lat. Dict. 1869.

Franien'ta, Linneus. Named from John Franken, a 
Swedish botanist and professor of medicine at Upsal, who died in 1661.

Frax'rnus, Virgil. L. for the Ash tree. The derivation of the name is uncertain; some have supposed it to be from G. phraxis, a separation, because the wood may be easily split; others from G. phrcasso, to enclose or hedge round; and some from L. frango, I break, from its brittleness; but the wood of the Ash is remarkably tough.

Fritulda'RIA, Lobel. L., fritillus, a dice-box; alluding to the form of the flowers.

Melea'gris, Dodonsus. G., a guinea-fowl; in allusion to the markings of the flower.

Funia'ria, Gesner. L., fumus, smoke; Pliny says because it makes the eyes water when applied to them, as smoke does. The old name was fumus terre, smoke of the earth.

GA $^{\prime}$ GEA. Named in honour of Sir Thomas Gage, Bart., a British botanist, who died at Rome in 1820.

GaLAN'thus, Linneus. G., gal, milk, and anthus, flower ; on account of its milk-white flowers.

GaLeob'Dolon, Dioscorides. G., gale, a weasel, and bdolon, fetid smell.

GaLeop'sis, Dioscorides. G., gale, a weasel, and opsis, appearance; because the tip of the flower is like the snout of the weasel.

Lad'anum, Dalechamps. G., ledanon, a gummy substance, which is still gathered from the Cistus creticus of Linneus. The G. names for the plant were ledon or ladon, ledanon or ladanon. It was applied by Dodonæus and the writers of his time to several kinds of Cistus, and by Dalechamps (158\%) to this plant. By Linneus it was used as a specific name, according to his rules. 
Tet'rahit, Dillenius. "Derived from G. tetras, four. Its stem has four very decided corners." - Théis. Name formerly given to some of the Hemp-nettles.

GA'LIUn, Dioscorides. G., gal, milk; from the plant having been used to curdle milk. This plant of Dioscorides was Galium verum of Linneus. An English name for it is Cheese-rennet, and the French call it Caillelait, in allusion to its former use.

Crucia'tc. L., literally, crucified, but intended to signify cross-shaped (crux, crucis, a cross) ; Crosswort, as we call it, from the leaves, which are four in a whorl. Formerly used as a substantive name, but now more usually spelt with a small letter, erroneously according to Linnean practice. Bentham, in his 'British Flora,' retains Cruciata. It was named Galium cruciatum by Withering. Camerarius gives the name Cruciata to a Gentian, "Gentiana minor," or "Cruciata." It is still called Gentiana Cruciata.

Aparine, Dioscorides. G. name for the plant; from apairo, I take, or lay hold of.

Mollu'go, Dodonæus. According to him, from the softness of its leaves (L., moll, soft), compared with Aparine. These two species were formerly classed together under the name Lappa, now used as a synonym of Arctium. Gastrid'Iuns. G., diminutive of gaster, the belly; a ventricle, or little swelling, as is seen at the base of the spikelet. Genis'ta, Pliny. L. name for the Broom. It has been given to several leguminous plants, as Broom, Gorse and Dyers' Green-weed. It is said by some to be derived from Keltic gen, a shrub, and by others from L. genu, a knee; but these conjectures seem fanciful, and of no particular value.

Gentra'na, Pliny. "Gentian was first discovered by Gentius, ling of Illyria" (Pliny); hence the name. The 
species alluded to is G. lutea, of Limeus, the roots of which are the Gentian of our shops.

Amarel'la, Linneus. Diminutive of L., amarus, bitter; i.e., a little bitter.

Pneumonan'the, Cordus. From G. pneumon, lung, and anth, flower.

Gera'Niuni, Dioscorides. G. name, from gercun, crane; in allusion to the beaked fruit; as we say, Crane's Bill. Robertia'num, Fuchs, who refers it "without doubt" to some old superstition. "According to Adelung so called from its being used to cure a disease knomn in Germany as the Ruprechts-Plage, from Robert, duke of Normandy."-Prior.

Ge'ur, Pliny. From G., geuo, I yield an agreeable flavour. Githa'go. See under Agrostemia.

Glad'rolus, or Gladi'olus, Dodonæus. L. for a little sword, referring to the form of the leaves. The name is often incorrectly pronounced Gladio'lus.

Grau'CIUn, Tournefort. G., glauc, bluish green; in allusion to the bloom of the leaves.

Glaux, Tournefort. G., from the colour of its leares, see Gradciuni. The name was used by Dioscorides for an entirely different plant.

GLYCE'RIA, R. Brown. G., glyce, sweet; in allusion to the sweet juices of some of the species.

Grapha'tium, Dioscorides. G., soft down or wool; the species are covered with it.

Good'yera, R. Bromn. Named after John Goodyer, a Hampshire botanist of the time of Gerard.

Grinsade'sia, R. Bromn. G., gymn, naked, and aden, a gland; because the glands are not contained in a pouch.

Granogranisie, or Grinogran'sia. G., gymn, naked, and gramme, a line; because the lines of sori are uncovered, or without indusium. 
Habena'ria, R. Brown. From L., habena, a thong, or strap; which the lip of the flower somerwhat resembles.

Hed'ERA, Pliny. L. for Ivy.

He'lix, Pliny, L., wound about, or twisted; another name for Ivy.

Heleoch'aris. See Eleocharis.

Hedran'thenum, Cordus. G., heli, sun, anthemum, flower. The reason for the name is uncertain. It has been erroneously supposed by poets, and others, that flowers called sun-flowers continually turn towards the sun. A more likely explanation of the name is that their blooming depends much upon the brightness of the sun. Some flowers, as Anagallis, Montia, Nymphæa, and this Helianthemum, our English Rock Rose, expand the best in bright sunshine, while others have a different habit, as Tragopogon:- "for it shutteth it selfe at twelue of the clocke, and sheweth not his face open vntill the next daies sunne do make it flower anew, whereupon it was called Go to bed at noone."-Gerard. Then again some plants come into bloom in the evening.

Helleb'orus, Dioscorides. G., hele (helein), take away, or remove, and bor, food. The name was originally given more especially to White Hellebore (Veratrum album, of Linneus), and Fuchs gives this as its meaning. Gerard tells us: "The root of the White Hellebore procureth vomit mightily, wherein consisteth his chief vertue."

Helnin'thia. G., helminth, a small kind of worm; referring to the form of the fruit.

Heloscia'diun. From G., helos, a marsh, and sciadion, an umbel.

Herac'leum, Pliny, Named from the hero Hercules. Pliny mixes up a number of plants under this name in hopeless confusion. 
Sphondyl'ium, Dioscorides. G., diminutive of sphondyle, a stinking insect; old name for the plant.

Hernin'sum, R. Brown. Derived from hermin, the knob or foot of a bed-post; in allusion to the shape of the tubers. Monor'chis. G., mon, single; in allusion to the single tuber. "Root of several thick woolly fibres, and one globular hairy linob, the size of a large pea, which is the source of the plant of the present year. One of these apparent fibres, rarely more, bears at its extremity a small young knob, destined to enlarge afterwards, and to flower in the following summer." Smith Eng. Fl.

Hernia'ria, Gesner. L., a reputed remedy for hernia, or rupture.

Hes'peris, Pliny. G., hesper, the evening; when the flower is particularly fragrant.

Hiera'ciun, Dioscorides. G., so called from hierac, a hawk; because birds of prey were supposed to strengthen their vision with the juice of these plants.

Pilusel'la, Matthiolus. Diminutive of L., pilosus, hairy, i.e., a little hairy.

Hrerochlo'e. G., hiero, sacred, and chloe, grass, Holy Grass; because it was formerly used to strew in churches.

Hippocre'prs, Linneus. G., hippo, horse, and crepis, shoe; from the form of the fruit.

HIppopha'E, Dioscorides. G., apparently from hippo, horse, and phao, I shine; but the exact meaning and application are not clear. The ancient name Hippophaes was not confined to the Sea Buckthorn, and doubts have been expressed whether it was applied to that plant at all. Pliny says: "These plants would appear too, to be remarkably well adapted to the constitution of the horse, as it can be for no other 
reason than this that they have received their name. Hardoin, however, thinks that the names hippophaes and hippopheston have another origin, and that they are compounds of phaos, lustre, from the brilliancy which they were said to impart to cloths, and hippos, in an augmentative sense, meaning 'great lustre." Note in Bohn's Ed. of Pliny's Nat. Hist. The meaning must be considered doubtful.

Hippu'ris, Linneus. G., hipp, horse, and our, tail. A name given by Dodonæus to Equisetum.

Hol'cus, Linneus. G., holcos, from helco, I extract; because it was supposed to have the property of drawing out thorns from the flesh.

Holos'teun, Dioscorides. From G., hol, all, and osteon, bone; "by antiphrasis, the texture being the very reverse, soft and delicate."-Théis.

Honcken'ya. Named after G. A. Honckeny, a German botanist, who died in 1805 .

HoR'DEum, Virgil. L. for barley. Its origin is dubious. Hотто'nia, Boerhaave. Named after Pierre Hotton, a professor at Leyden, who died there in 1709.

Hu'nulus, Linneus. From L., humus, soil, the ground; figuratively low, or mean. It has been suggested that without support the plant would grow on the ground.

Lu'pulus, Brunfels. From L., lupus, a wolf. Pliny calls the plant "Lupus salictarius," meaning literally the "willow wolf." It probably took this name from the tenacity with which it clung to willows. Lupulus was an officinal name for the Hop.

Hutchin'sia. Named in honour of Miss Hutchins, of Bantry, Ireland, who was an excellent and wellknown botanist.

Hyacin'thus. See Agraphis. 
Hydroch'Aris, Linneus. From G., hydro, water, and charis, elegance. Pretty water plants.

Mor'sus-r'a'ne, Dodonæus. L., mor'sus, a biting, rance, of a frog. Frog-bit; frogs were supposed to eat it.

Hydrocot'yle, Tournefort. From G., hydro, water, and cotyle, cup; from the species growing in watery places, and bearing leaves that are somewhat cupshaped. See Cotyuedon.

Hynenophyl'Lum, Smith. From G., hymen, membrane, and phyllon, leaf; Film Ferns.

Hroscy'anus, Dioscorides. G., hyos, hog's, and cyanos, bean; because hogs are said to eat the fruit, which is something like a bean.

Hyper'ICUnr, Dioscorides. G., the meaning is doubtful. It has been supposed to be derived from hyper, above, and eikon, image; as being used for an amulet against spirits. Hyperi'cum would seem the correct pronunciation, but it is not usual.

Androsce'mum, Dioscorides. G., andros, man's, cema, blood. Lonicerus tells us because, if the seed or the flower be rubbed, it will give out "man's blood." Fuchs puts it, because "they have said that the flower, rubbed in the fingers, emits a blood.coloured juice."

Hүроснж'ris, Theophrastus. From G., hypo, for, and cheros, a hog: the roots being eaten by that animal.

IBE'RIS, Dioscorides. Named from Iberia, or Spain, where many of the species grow.

I'Lex, Pliny. L. for the Holm Oak, or Ever-green Oak. Aquifolium, Pliny; i.e., acui-folium, or pointed leaved, L. Ille'CEbrun, Dodonæus. L., illecebra, an enticement, or attraction; a name formerly given to Stonecrops. Fuchs uses it for Sedum Telephium, and Dodonæus for Sedum acre, of Linneus. Applied by Linneus to this lowly, but pretty little plant. 
Inps'triexs, Dodonæus. Impatient, from the sudden opening of the capsule if touched when it is ripe.

No'li-me-tan'gere, Columna. L., touch me not; for the same reason as the last. Gerard gives this name to the Squirting Cucumber (Ecbalium officinarum), which has a very remarkable prorision for the distribution of its seeds, for when quite ripe the fruit parts from its stem, and the contents are discharged with such force as to convey them a considerable distance.

Ix'Ula, Horace. L., for Elecampane, said to be from G., Helen; the plant being supposed to bave sprung from the tears of the heroine of the Trojan war.

Cony'za, Hippocrates. G. name for the plant.

Hele'nium, Dioscorides. See Inula; the derivation is the same.

I'RIS, Theophrastus. G. for the rainborv; from the varied colour of the flowers.

Pseud-ac'orus, Linneus. G., pseud, false, and Acorus, which see. It is an older name than Linneus; thus Matthiolus calls it Pseudo-acorum, which is practically the same name, though not identically.

IsA'TIS, Dioscorides. G. name of the plant.

ISNAR'DIA, Linneus. Named after Antoine d'Isnard, a botanist, and professor at Paris, who died in 1743.

Isö̈'tes, Linneus. G., iso, equal, or alike, and etos, the year; meaning evergreen.

Isol'epis, R. Brown. G., iso, equal, and lepis, a scale; on account of the uniform size of the glumes.

Holoscho'nus, Dalechamps. Greek for a kind of rush.

JAS'IONE, JASI'ONE, JASIO'NE. The last accentuation is given by Withering, but may be considered quite out of date. Name of Theophrastus; G., generally supposed 
to have been given by him to some sort of Campanula, but we have no certain knowledge about it.

Jun'cus, Pliny. L. for a rush ; from the verb jungo, to join, or bind, because of their use for tying.

Junsp'erus, Pliny. L. for Juniper.

Krap'pia, Smith. Named in honour of J. L. Knapp, an

English botanist, and author of a work on the British Grasses: he died in 1845 .

KNaur'sa, Linneus. Named in honour of Christian Knaut,

a botanist of Saxony, who flourished in the latter

half of the seventeenth century, and died in 1716.

Kobre'st. Named in honour of MI. de Kobres, of Augsburg, a patron of Botany.

Koele'RiA. Named in honour of George Louis Koeler, author of a work on German and French Grasses, who died in $180 \%$.

Ko'NIGA, Brown. "Name revived by Mr. Brown, from the Konig of Adanson, and altered by him to Koniga, in order to commemorate the important services rendered to Botany by $\mathrm{Mr}$. König; of the British Museum."-Hooker and Arnott.

LACTU'CA, Pliny. From L., lac, millk; because of the millky juice which flows from the broken stems of many of the species.

LAGU'Rus, Linneus. G., lag, hare, and our, tail ; Hare'stail Grass.

LA'niusr, Pliny. G., laimos, throat; on account of the throat-like corolla.

LaPSA'Na, Dioscorides. G., lapazo, purge; by reason of its medicinal property.

Lastre'a, Presl. "The name of the genus in its original form (Lastræa) was giren by Bory de St. Vincent, in homour of MI. Delastre, of Chatellerant, a zealous 
botanist and microscopist. Presl in adopting it, and giving it a new application, writes it Lastrea."Moore, 'Nature-printed British Ferns.'

LAture'A, Linneus. G., lathre, hidden, or concealed; the plant being often much concealed by dead leaves. Lath'yrus, Theophrastus. Name for some leguminous plant; the exact one is not known.

Aphiaca, Dioscoricles. G., aphace. Name formerly given to two or three small leguminous plants. Dodonæus gives us a picture of this plant under the name Aphace. Matthiolus gives us Vicia sativa (of Linneus) as the Aphace of Dioscorides.

Nisso'lia, Tournefort. Named in honour of M. G. Nissole, a professor of Botany at Montpellier, who died there in 1734 .

Lavate'ra, Tournefort. Named in honour of the two Lavaters, physicians and naturalists of Zurich, and friends of Tournefort.

LeEr'sia. Named in honour of John Daniel Leers, a German botanist, who published a 'Flora Herbornensis,' and died at Herborn in 1774.

Len'na, Theophrastus. G. name for the plant, the origin of which is unknown. The only derivation $I$ have seen suggested is from lepis, a scale, but this is scarcely probable.

Leon'todon, Linneus. G., leon, lion's, and odon, tooth ; from the tooth-like margins of the leaves.

Tarax'acum, Lonicerus. G., tarass, change; on account of its supposed effects on the blood.

Leonu'rus, Linneus. From G., leon, a lion, and oura, a tail; on account of the supposed resemblance.

Cardi'aca, Fuchs. L., affecting the stomach; because of its repute formerly as a remedy for that disease of the stomach that we call heartburn. Fuchs attributes 
the name to its property of allaying palpitation of the heart. The G. word cardiacos refers both to the heart and the stomach. The name was an officinal one.

Leprd'Iusi, Fuchs. G., lep, scale; from the form of the little pouches, or seed-vessels; or, as Fuchs reports, because it removes scales and spots from the face.

Drába. See earlier.

Leptu'rus, R. Brown. G., lept, slender, and our, tail; referring to the slender spikes.

Leuco'sun, Dioscorides. G., leuc, white, and ion, violet. IIIGUs'ticuxr, Dioscorides. Named from Liguria, where it abounds.

Ligus'trun, Pliny. L., lig, bind; on account of the branches having been sometimes used for such purposes.

Lir'IUn. L. for Lily, in G. leirion; a very ancient name, of which the origin is unknown.

Linnaxth'Engn. G., limn, marshy lake, and anthemum, flower.

Lrmosel'LA, Linneus. L., limus, mud; the plant growing in muddy places.

Lina'Ria, Tournefort. From lin, flax; from the resemblance of the leaves of some species to those of flax, as Linaria vulgaris, which we call Toad-flax.

Cymbala'ria, Matthiolus. From L., cymbalum, a cymbal. Dioscorides gives this name to his second species of Cotyledon, which is our London Pride. There was a good deal of confusion in the use of the name "Navel-wort," in various Latin forms: thus Fuchs says it was one name for Sow-bread (Cyclamen), and Dodonæus as a name of Pennywort (Hydrocotyle). Matthiolus points out that this plant, in his time commonly called Cybalaria, is not the Cymbalaria mentioned by Dioscorides. He gives pictures of the three plants, viz., first and second kinds of Cotyledon of Dioscorides, and Cymbalaria. See Cotruedox. 
Linnes'A, Gronovius. Named in honour of Limneus, with his concurrence, by his friend Dr. J. F. Gronovius. It is a "little northern plant, long orerlooked, depressed, abject, flowering early, which Linneus selected to transmit his own name to posterity." - Smith, Eng. Fl.

Linosy'ris. Named from L., lin, flax, and osyris, an appellation given by Pliny to a plant with supple branches, and leaves like flax.

Lr'xux, Theophrastus. From G., linon, flax, changed in L. to linum.

LIP'ARIS. G., liparos, fat, or unctious to the touch.

Lis'tera, R. Brown. Named in honour of Dr. Martin Lister, a British naturalist, who died in 1711.

Ni'dus-a'vis. L., nidus, nest, avis, of a bird.

Lithosper'numi, Dioscorides. G., litho, stone, and sperm,

seed; on account of its seeds being very hard.

Litrorel'LA, Linneus. L., lit, the shore; which is its place of growth.

Lloyd'IA. Named in honour of Mr. Edward Lloyd, a learned Welsh antiquarian and naturalist of the seventeenth century, who first discovered this plant in Britain.

Lode'Lia, Plumier. Named in honour of Lobel. See p. 40. Dortman'na, Linneus. Named in honour of Dortmann, a

Dutch apothecary, who did good service to Botany.

Loiseleu'rea. After the French botanist Loiseleur Deslongchamps, who published a Flora of France, and other botanical works, and died in 1849 .

Lor'iusr, Pliny. L. for Darnel.

Lona'ria, Willdenow. From G. loma, the hem or border of a robe; from the marginal sori.

Lortce'ra, Limneus. Named in honour of Lonicer. See p. 38. Iericly'menum, Dioscorides. From G. pcri-clcio, I enclose 
or entrine; in allusion to the method of ascent of the Honeysuckle stem.

Lo'Tus, Theophrastus. Application uncertain; it has been supposed that it is one of the kinds of the lotos, of the Greeks.

Ludwig'is. In honour of Christian Gottlieb Ludwig, a professor of Botany at Leipsic, where he died in 1773 .

Lu'zula. Smith (Eng. Fl.) calls this genus "Luciola" instead of Luzula, and remarks on it as being "an indispensable correction in the orthography of the name." He continues:- " The hairy heads of flowers, wet with dew, and sparkling by moonlight, gave the elegant Italians an idea of their lucciole, or glowworms; sometimes written luzziole, but this is a provincial corruption. Hence, however, Joln Bauhin got the name of Gramen luzulce, or Glow-worm Grass, for he never called it Luzula, which would have been the same as actually calling it a glow-worm." Notwithstanding this correction the genus continues to be called Luzula. All the names are derived from L., luceo, I shine.

Lrcríxis, Theophrastus. From G., lychnos, a lamp; "the thick cottony substance on the leares of some species, or some similar plant, having been employed as wicks for lamps;" or "from the flame-like flowers of some species." There is some difference of opinion as to the exact reason of the name.

Flos-cu'culi, Tragus. L., flos, flower, cuculi, of the cuckoo. A name that has been given to different plants that flower in April and May, "when (as Gerard expresses it) the Cuckowe doth begin to sing her pleasant notes without stammering;" this Dodoneus calls the May Flower (Cardamine pratensis), Flos-cueuli.

Tisca'ria, Lobel. From I.., riscum, mistletoe, and also 
bird-lime (made from it). Lobel calls this plant Viscaria, and Gerard calls it in English "Catch-fly, or Bird-lime-wort."

LyCOPOD'IUn, or Po'DIUn, Clusius. G., lyco, wolf, and podion, little foot; alluding to the appearance of the branches of some of the species.

Sela'go, Dillenius. G., sela, shining.

Lycop'sis, Dioscorides. G., lyc, wolf, and opsis, a face; because of some fancied resemblance of the flowers to a wolf's face.

Ly'copus, Fuchs. G., lyco, wolf, and pous, foot; from the shape of the leaves.

LysñA'Chia, Dioscorides. Lysi, dissolving, and mache, battle. Loose-strife; because it was said to appease the strife of oxen at the plough if put about their yokes; or others say that it is named in honour of Lysimachus, a king of Macedonia, who was killed in battle 281 years before Christ, in the 80th year of his age. He is said to have discovered the virtues of the plant. Nummula'ria, Dodonæus. From L., nummus, coin; Moneywort or Herb Twopence; from the shape of the leaves. Fuchs mentions the name, but himself calls the plant Centum morbia (a hundred diseases), on account of its great medicinal repute.

Lyth'run, Linneus. G., lythron, blood; it is said from the colour of the flowers.

Salica'ria, Tournefort. Like a Willow, L., salix. Willowherb. This plant was formerly classed along with the Willow-herbs, which were then called Lysimachia, and this particular one Lysimachia purpurea spicata.

Matanth'enumr, Mœnch. G., mai, May, and anthemon, a flower. 
Matach'iunr. The word would seem to mean "Mallowlike" (G., malache, a mallow), but the plant has no resemblance to a mallow, and the explanation is more likely to be G., malakos, soft or feeble; from the nature of the plant.

MaLAx'Is. G., a softening; on account of the tender nature of the plant.

$\mathrm{MAL}_{\mathrm{VA}}$, Pliny. L. for mallows. Altered from the G. name malache, which is from malass, soften; in allusion to the emollient properties of the species.

Marku'biusr, Pliny. The meaning of the name is uncertain. Matrica'ria, Brunfels. Named from its reputed medicinal virtues.

Chamomil'la, Tragus. G., chamaimelon, meaning literally ground apple; so called (according to Gerard) because the flowers have the smell of an apple.

Parthen'ium, Dioscorides. G. name for the plant.

Matthi'ola, Plumier. Named in honour of Matthiolus. See p. 37.

Meconop'sis. From G., mecon, a poppy, and opsis, a face or appearance.

MIedica'Go, Tournefort. The medice of the Greeks; so called because it was introduced into Greece by the Medes.

Melan' pyrun, Theophrastus. From G., melas, black, and pyros, wheat. Its seeds resemble wheat, and are said, when mixed with it, to make the bread black.

Mé'ICA, Dodonæus. "Melica, or Melliga, name given in Italy to the Sorghum vulgare, on account of the sweet flavour of its stem (L., mel, honey), was applied by Linneus to this somewhat allied genus." - Hooker and Arnott.

MeLilo'tus, Pliny. From L., mel, honey, and Lotus, which see. 
Melis'sa, Brunfels. G. for a bee, and also for honey. Bees are fond of it.

Melit'tis, Pliny. From G., melissa, a bee; because of its yielding honey to bees.

Melissophyl'lum, Rivinus. From G., melissa, a bee, and phyllon, a leaf; for a similar reason to the last.

Men'тна, Theophrastus. G., mintha, or minthe, a fabled nymph who was changed into the herb Mint by Proserpine.

Pule'gium, Pliny. L. name for Pennyroyal, from pulex, a flea; because it was supposed to kill fleas. "The blossom of it, fresh gathered and burnt, kills fleas by its smell."-Pliny.

Menyan'thes, Dioscorides. G., men, month, and anth, flower; it is said from the duration of the flowers being a month.

Menzie'sia. Named in honour of Archibald Menzies, surgeon and naturalist to the Expedition under Vancouver, in 1790 : he died at Kensington in 1842.

Mercuria'tis, Pliny. Named after the god Mercury, who is said to have discovered some virtues in it.

Merten'sia. Named in honour of F. C. Mertens, a German botanist, who died at Bremen in 1831.

Mes'pilus, Theophrastus. G., mespile, the medlar. ME'Un, Dioscorides. Supposed to be G., meon, of Dioscorides.

Athaman'ticum, Pliny, who says: "because, according to some, it was first discovered by Athamas; or else because, as others think, that of the best quality was found upon Mount Athamas." Athamas, according to the ancients, was king of Thebes, in Bœotia, and son of Eolus, who was the ling of storms and winds, and reigned over Eolia; he was the son of Hippotas, a Trojan prince, who was changed into a river, \&c. 
Mru'runr, Pliny. From L., mille, a thousand; on account of its fertility. "The Latin name for the true Millet misapplied."-Dr. Hooker, 'Student's Flora.'

Mrn'ulus, Linneus. L., mim, mimic; hence Monkey Flower.

M匹N'chia. Named in honour of Conrad Mœench, Professor of Botany at Hesse Cassel.

Molin'ia. Named in honour of the Rev. Juan Ignazio Molina, who wrote an account of the Natural History of Chili, published in 1782, and died in 1829.

Mone'ses. G., mon, alone; on account of the solitary flowers and combined petals.

Monot'ropa, Linneus. G., mon, one, and trepo, I turn; the flowers all turning one way.

Hypop'itys, Dillenius. From G., hypo, under, or about, and pitys, a Fir-tree; the plant grows in Fir woods.

Mon'tia. Named in honour of Guiseppe Monti, Professor of Botany and Natural History at Bologna, who died there in 1760 .

Mulge'Diuns. From L., mulgeo, I milk; on account of its milky juice.

Mus'cari, Clusius. Late L. musc, musk; on account of the scent yielded by one species.

Mroso'trs, Dioscorides. G., myos, mouse's, and ot, ear' from the shape of the leaves.

Mrosu'rus, Dodonæus. G., myos, mouse's, and ourca, tail ; from the elongated spike of the seed vessels, resembling a mouse's tail.

MYri'cA, Theophrastus. G. name for Tamarisk.

Ga'le, Bauhin. The Myrtus brabantica of Dodonæus and Gerard. Gerard calls it in English Sweet Willow, or Gaule, and gives the Dutch name as Gagel. Gale seems to be an altered form of the word. It is now called Gall, or Gall-bush, in Scotland. 
Myriophyt'Lunr, Dioscorides. G., myrio, myriad, and phyllon, leaf; because of its many leaves.

Mrr'RHIS, Dioscorides. From G., myrrha, myrrh; on account of the scent of the leaves.

NAI'As, Linneus. Named after the naiads, or water nymphs. Narcis'sus, Theophrastus. The name of a beautiful youth of heathen mythology, who was said to be changed into a plant. This is usually set down as the origin of the name. Pliny says that it has received its name from "narce" (torpor) on account of its effects, and not from the youth Narcissus, mentioned in fable; and this derivation is supported by Théis. Prior writes :- " an instance, among many more, of a legend written to a name; for as an old poet, Pamphilus, remarks, Prosperine was gathering Narcissi long before that youth was born."

Pseu'do-narcis'sus, Dodonæus. G., pseudo, false, and narcissus (see above).

NAR'Dus, Theophrastus. G. name; a plant, from the flowers of which a sweet-smelling oil was prepared. There is no apparent reason why the name should have been applied to this genus.

Narthe'ciusi. From G., narthex, a rod; probably from the elongate, straight raceme of flowers. The name Narthex was given by the Greeks to quite a different plant, a species of Ferula, the genus from which we obtain Assafœetida.

Nastur'tiuar, Pliny. L., nus, nose, and tortus, twisted; from the smarting sensation which its pungency causes to the nostrils.

Neoti'xea. "The name of this genus was originally Tinea, to which the younger Reichenbach prefixed Neo, to distinguish it from Tinea, a well-known genus of 
small moths."-E. B. Tinea is L. for a moth, and Neo is a G. prefix signifying new, or fresh. Such names, composed of Greek and Latin, are not considered good (see canon 10, p. 64); further, names of members of the animal kingdom are not allowed by Linnean rule to be used for plants (see canon 17, p. 65).

Nep'ETA, Pliny. Named, according to Linneus, from Nepi, a town in Italy; others say from nepa, a scorpion, for whose sting this plant was considered a cure. See Nepeta, under CaLanintira.

Cata'ria, Dodonæus. From L., catus or catta, a cat. "The latter herbarists do call it Herba Cattaria, and Herba Catti, bicause the cats are very much delighted herewith; for the smell thereof is so pleasant vnto them, that they rub themselues vpon it, and wallow or tumble in it, and also feede on the branches and leaues very greedily."-Gerard.

Glecho'ma, Linneus. From G., glechona, Pennyroyal.

Nephro'dium. G., nephros, the kidneys, from the kidneyshaped involucres. The British species are all included in the sub-genus Lastrea, which is distinguished by having free veins.

Nu'PHAR, Smith. Arabic, nauphar.

Nymphe'A, Theophrastus. G., referring to the water nymphs, or naiads of ancient mythology, who presided over rivers, springs, and fountains.

OBI'ONe, Gärtner. Prof. Asa Gray says:-" Origin of the name unknown, unless from the river Obi, in Siberia, whence the original species came."'

Evan'the, Theophrastus. G., on, wine, and anth, flower; alluding to the smell of the flowers.

Plellan'drium, Pliny. From G. "Dr. Poth always 
writes the old name Phelandrium; which agrees with an etymology I have hazarded in Rees' Cyclopædia, v. 27, from pheleo, to be treacherous, alluding to the poisonous nature of the plant."-Smith, Eng. Fl.

Evothe'ra, or E'votiI'era, Theophrastus. G., ceno, wine and therca, searching, catching, or acquiring; "the roots having a vinous scent when dried: they were also formerly eaten as incentives to wine drinking, as olives are; hence the name was changed from onagra, the ass food, to conotherc, the wine trap. We are not sure that the change was necessary." $-\mathrm{E}$. B.

Onon'ruchis, or Oxobry'chis, Dioscorides. G., ono, ass, and brych, bray; it is said from the animal braying to get at it.

Ovo'vis, Theophrastus. G., ono, ass; because the ass eats it. Onopor'dun, Pliny. G., ono, ass, and perd, crepitation; from the carminative effects (according to Pliny) upon asses when they eat of it.

Acanth'ium, Dioscorides. G., has been supposed to be the acanthion of Dioscorides, from acanth, thorn or prickle. Ophroglos'sunr, Tragus. G., ophio, serpent, and gloss, tongue; the Adder's Tongue Fern. The allusion is to the shape of the fertile frond, which is also the origin of the English name.

Opir'Rrs, Pliny. G., ophrys, the eyebrow. Pliny includes it, among some others, to apply to the hair: "Lysimachia imparts a blonde tint to the hair, and hypericon, otherwise called corison, makes it black. The same, too, with ophrys," \&c. The Ophrys of Pliny seems by his description to be our Tway-blade (Listerca ovata). The name was applied to this genus by Linneus. Théis remarks that the calyx in the greater part of these plants resembles the eyebrow by its arched form. 
Or'chrs, Theophrastus. G. name for plants having a double tuberous root.

Mo'rio, Linneus. From L., morus, a fool ; Fool's Orchis, an old name for the plant.

Orig'anur, Theophrastus. G., ori, hill, and gan, joy; the delight of the mountains, of which the species are ornaments. Matthiolus remarks that with the ancient herbalists the history of the different species of Origanum is various and confused.

Orivithogaluir or Ornithog'alumi, Dioscorides. G., ornitho, bird, and gal, milk.

Orni'triopus, Gesner. G., ornitho, bird, and pous, foot; from the similarity of the seed-vessels to a bird's foot.

Orobanch'e, Theophrastus. G., orob, in this case any kind of leguminons plant, and anche, strangle; from their being parasitical on the roots of such plants.

Osnun'DA, Lobel. "After the god Thor (Osmunder)."-Théis. Ox'Alis, Pliny. From G., oxy, sharp, or acid. The Oxalis of Pliny is the Rumex Acetosella of Linneus, not his Oxalis Acetosella.

Acetosel'la, Linneus. From L., acet, sharp, or sour-tasted (acidus, acid or sour); an old officinal name.

Oxycoc'cos. See under Vacciniun.

Oxyr'IA, R. Brown. G., oxy, sharp, or acid; on account of the acid flavour.

OXYт'Ropis. G., oxy, sharp, and tropis, a keel; a distinguishing character of the genus, which has a narrow-pointed keel (carina) - the name for the two lower petals of a papilionaceous or butterfly-shaped flower, such as the pea, which together resemble the keel of a boat.

Peo'xra, Theophrastus. G., named in honour, it is said, of the celebrated physician Pron, who cured the wounds which the gods received during the Trojan war. 
PaN'ICUn, Linneus. From L., panis, bread; the seeds of some species being used to make bread.

Crus-galli, Linneus. L., crus, leg; galli, of a cock; old officinal name.

PAPA'ver, Pliny. "So named because it is administered with pap (papa in Keltic) to induce sleep."-Hooker and Arnott. The etymology is dubious.

Argemo'ne, Dioscorides. G. name of the plant, from argema, on account of its use formerly for the cure of cataract in the eye. See Agrimonia.

Rhce'as, Lobel. Called by the Greeks mecon, poppy, rhoias. Rhoia (rhæa) means a Pomegranate, which the capsules somewhat resemble. Or perhaps from rheo, I flow; which derivation seems to have been more generally accepted, for Dodonæus and the other botanists of that time give Papaver liquidum as the L. name, which might have been applied on account of its quickly-falling petals, or seeds, or the milky juice which flows from the stems if they are broken: though, as pointed out by Gerard, such distinctions are not more applicable to this kind of poppy than to others. Parieta'ria, Pliny. From L., paries, a wall; the species frequently growing on walls.

PAR'Is, Matthiolus. L., equal, on account of the regularity of its leaves and flowers. It was formerly called Herba Paris, or Paris herba, and we call it Herb Paris.

Pannas'sia, Linneus. From Mount Parnassus, though this "grass of Parnassus" is by no means peculiar to that locality. It was called Grass of Parnassus (Gramen Parnassium) by Dodonæus, and others of his time.

Pastin'ACA, Pliny. L. for a parsnip, or carrot; from pastus, food.

Pedicula'nis, Gerard. From L., pediculus, a louse; because it was supposed to produce a lousy disease in sheep. Pep'LIs, Linneus. From G., peplion, anciently applied to 
the genus Portulaca, now to this one, which is similar in habit.

Por'tula, Dillenius. L., portulaca, Purslane.

Petasítes, Dioscorides. From G., petasos, a covering to the head, or an umbrella; on account of the great size of its foliage.

Petroselínum, Dioscorides. From G., petros, rock, and selinon, parsley; as it grows in rocky places.

Peuced'Anuar, Dioscorides. From G., peuce, a pine tree and danos, a gift; on account of a resinous substance that exudes from some of the species.

Ostru'thium, Dodonæus. This name was applied to Masterwort, on the Linnean system of nomenclature, by Koch.* It is an old name for the plant, which was formerly also called Astrantia and Imperatoria. Dodonæus says :-_"Some recent authorities call this plant Imperatoria, as well as Astrantia, and some Ostrutium, the same as Struthion, but it differs greatly from Struthion." Struthion is an old Greek name of Theophrastus for some unrecognized plant, and is mentioned by Pliny, who calls it Radicula, in Latin. More recently it has been given to different plants, as to Sneezewort (Achillea Ptarmica), and to our garden plant, the Scarlet Lychnis (Lychnis Chalce(lonica), which Dodonæus calls Flos Constantinopolitanus. I cannot trace the meaning of Ostruthium.

Phal'aris, Dioscorides. G., phal, shining; Canary-seed being very glossy.

Phle'un, Pliny. G., phleos, formerly applied to the Reed-mace, to which this genus bears some distant resemblance.

* Wilhelm Daniel Joseph Koch was born at Kusel, near DeuxPonts, in 1771, and died at Erlangen in 1849. He published several botanical works, the most important being a Synopsis of the German and Swiss Flora. He is celebrated for his extensive kmowledge of European plants. 
Phragmítes, Trinius. G. name, meaning material for an enclosure; these reeds being used for thatching; garden fences, \&c. Arundo Phragmites was the name given by Linneus and numerous other authorities to the common Reed.

Phyllod'oce. L., name of a sea nymph in ancient mythology.

Physosperímun. From G., physa, a bladder, and sperma, a seed; from the loose covering to the seed.

Phyteu'ma, Dioscorides. G., "plyyteuma (the same as phyton), the plant; given par excellence to some medicinal plant by the ancients, but which probably bore little or no resemblance to the present."Hooker and Arnott.

Pr'cris, Dioscorides. G., picros, bitter; as are many of this genus.

PruUla'Ria. L., pilula, a little pill; which its fructification resembles.

Pimpinel'́la, Fuchs. Altered from L., bipennula, or twice pinnate; in allusion to the divisions of the leaves.

Saxif'raga. From the resemblance of the lower leaves to some species of Saxifraga, which see.

Prnguic'ula, Gesner. From L., pinguis, fat; on account of the texture of the leaves; hence the English name Butterwort, and the French Grassette.

PI'nus, Pliny. L. name for the plant.

Planta'Go, Pliny. L. name applied to some plants of this genus, and also to the Water Plantain (Alisma). Its origin is unknown.

Coron'opus, Dioscorides. From G., coron, crow, and pous, foot; crow's foot. Smith says:- "There has been much controversy respecting the Coronopus of ancient author's, some taking it for Cochlearia Coronopus, of Limneus, others for his Plantago Coronopus, others for Myosurus, or for Achillea Ptarmica, while 
that of Pliny scems by his description very different from all these, as well as from what Dioscorides intended. . . . It seems to me that the name in question was applied by the ancients to rarious plants whose roots were crowned with radiating depressed leaves."

Ianccola'ta. L., lanceolate, or tapering to each end; in allusion to the leaves. Lanceola, or Lanceolata, was the old officinal name for this plant, as may be found in the works of Fuchs, Lonicer, ic. It was not spelt with a capital letter by Linneus, or any one after him, so far as I know, nor is it a name that is worth commemoration in that way. Still it should be mentioned.

Po'A, Theophrastus. G. for Grass.

Polemóxium, Dioscorides. G. and L. name for Greek Valerian, or Jacob's Ladder; after Polemon, a king of Pontus, who died at an adranced age, about 2r0 years before Christ; or according to Pliny from polemos, war, the plant having caused a war between two kings, who each of them claimed its discorery!

Polycar'pos, Dalechamps. From G., poly, many, and carpos, fruit; our English name is Allseed.

Poryg'Ala, Dioscorides. From G. poly, much, and gala, milk; from its reputed property of promoting the secretion of millk.

Polygon'atum, Dioscorides. From G. poly, many, and gonat, knee, or joint; on account of the numerous knots, or swellings, of the root, according to Fuchs; or perhaps on account of the many nodes, or joints, of the stem.

PolyG'oxur, Dioscorides. From G. poly, many, and gon, knee, corner, or joint; from the numerous joints of the stem,-as we say Knot-grass. 
Bistor'ta, Matthiolus. L., twice-twisted (bis-torta); al. luding to its roots.

Fagop'yrum, Dodonæus. It was also called Fagotriticum (L. Fagus, a beech, and Triticum, wheat). Fagopyrum is the same name in G., phegos, a beech, and pyros, wheat; on account of the resemblance of the three-cornered seeds to beech-mast. See FAgus.

Convolv'ulus. See the genus earlier; so called from its twining habit.

Hydropi'per. See under Eiatine.

Persica'ria, Pliny. From L. persicus, a peach tree; on account of the resemblance of the leaves.

Polypod'IUn, or po'diun, Theophrastus. From G. poly, many, and poction, a little foot; on account of the divisions of the rhizome.

Dryop'teris, Dioscorides. G., dryo, oak, and pteris, fern; Oak Fern. Five of our British ferns have been called Dryopteris by different authorities at different times.

Phegop'teris, Linneus. From G. phego, a beech tree (see FAGUS), and pteris, a fern. Beech Fern.

Polypo'Gox. From G. poly, much, and pogon, beard; from the bearded appearance of the panicle.

Polys'tichun. From G. poly, many, and stichos, order; "applied to the shield ferns in allusion to the numerous regular lines of sori, which are seen distributed over the fronds."-Moore.

Pop'ulus, Pliny. L. name for the Poplar; the derivation is doubtful. It has been suggested that it is an altered form of palpalus, from G. pallomai, to quiver, or shake; which the leaves of the Aspen and other Poplars are remarkable for doing.

Potamogéton, Dioscorides. G., potamo, river, and geiton, a neighbour. They are water plants. 
Potextilíta, Brunfels. From L. potent, powerful; on account of the medicinal virtues attributed to some of the species. It is a comparatively recent name, and was applied by Matthiolus, Fuchs, and others of that period, to Potentilla Anserina. Gerard also gives Potentilla major as one of the names of Meadow Siveet.

Anseri'na, Tragus. I have put down Tragus opposite this name, but it was in common use in his time officinally for this plant, and continued in use for some time afterwards; thus you may find it in Linneus' 'NIateria Medica' as the officinal name for Potentilla. Lonicerus says:- "By what name the ancients called that which we now-a-days call Potentilla does not appear. It is Genserich of the Germans, meaning the same as Anserina, because geese rejoice in it for food." The derivation is from L., anser, a goose; in English it is sometimes called Goose-grass. Another old name for it was Argentina, from L., argentum, silver; Silver-weed, the name we commonly give it in English.

Fragarias'trum. From Fragaria (which sce), on account of the resemblance. It was called by Linneus Fragaria sterilis, and has since been called Potentilla Fragaria, and P. fragarioides. The English names are Barren Strawberry, and Strawberry-leaved Cinquefoil. See Raphanistrum under Raphanus.

Tormentil'la, Matthiolus. By Dodonæus this is set down as a recent name, the older being Septifolium, or Septfoil. I do not meet with any explanation of Tormentilla: in French it is Tormentille. The reference would seem to be to its medicinal properties as an astringent in bowel complaints, for which it is still used. L., tormina, dysenteric pains. 
Pote'rivar, Linneus. G., literally a drinking cup, but in this case alluding to a beverage. According to Pliny it was taken in wine, and also as a decoction mixed with honey for different complaints. It is a name of Dioscorides, but was applied by him to quite a different plant from the Salad Burnet. Poterium, in its present application, must be taken as a fresh invention. Théis remarks that "the English use it in the preparation of a refreshing beverage which they drink in hot weather. It is called cool-tankard."

Sanguisor'ba. See genus later.

Prini'ula, or Prínerula, Matthioltis. From L. mimus, first; on account of its being one of the earliest spring flowers.

Prixel'ta, Brunfels. Named from the German brünne, the quinsy, which it was supposed to cure: hence also called Brunella by some old authorities as Dodonæus, Rivinus, and more recently by Tourne"fort and Bentham, while Fuchs, Bauhin and other's used the softer sounding Prunella.

Pru'xus, Pliny. L. for Plum Tree. The G. name was proune.

Cer'asus, Pliny. L. for the Cherry Tree, which was brought by Lucullus from Cerasus, in Pontus, to Italy.

I'c'clus, Theophrastus. Prunus Padus is the name given by Linneus to the Bird Cherry. Padus was the name of the river Po, and Pliny tells us:- "Metrodorus, of Scepsos, informs us that this river has obtained its name of Padus from the fact that about its source there are great numbers of Pine Trees, which in the Gallic language are called 'padi."” I know of no other connection between Padus and a tree. 
Psaminas. G., pscomme, sand; on account of the plant growing in the sand on the coasts.

Pter'is, or Pte'Ris, Theophrastus. G., a fern.

Pulica'Ria. See under Inula, p. 136.

Pulmoxa'sia, Gesner. From L. pulmo, a lung; because the spotted leaves have somewhat the appearance of lungs. Hence, according to the doctrine of signatures, which taught that such marks on plants point out their medicinal uses, the Pulmonaria was supposed to be useful in lung diseases.

Py'rola, Brunfels. From L. pyrus, a Pear-tree; from the resemblance of the leaves to those of a Pear-tree, according to Lonicerus.

Pýrus, Pliny. L. for Pear-tree (pyrus or pyrum).

A'ria, Theophrastus. Pyrus Aria is given by Gerard as the Aria of Theophrastus.

Ma'lus, Varro. L., an Apple-tree.

Quer'cus, Pliny. L., an Oak-tree.

Ro'bur, Pliny, L., a kind of Oak.

Rad'IOLA, or Radi'Ola, Diminutive of L. radius, because the cells of the ripe capsule diverge like the rays of a little wheel.

Millegra'na, Gerard. L., mille, a thousand, or innumerable, grana, grains, or seeds; we call it Allseed.

Raxux'culus, Pliny. Diminutive of L., rana, a frog; a little frog, most of the species growing in those moist situations where young frogs are to be found, and they flower at about the same time as that when frogs are young.

Fica'ria, Brunfels. From L. ficus, a fig; on account of the form of its roots.

Flam'mula, Dodoneus. L., diminutive of flemma, a 
flame; a little flame. The reference is to the redness or inflammation caused by the application of the leaves to the skin, a property possessed by most of the Crowfoots. Some remarks of Gerard in reference to this property are quaint and amusing. This he says of Crowfoots in general:- "Many do vse to tie a little of the herbe stamped with salt vnto any of the fingers against the paine of the teeth, which medicine seldome faileth; for it causeth greater paine in the finger than was in the tooth, by the meanes whereof, the greater paine taketh away the lesser." The name Flammula is also given to a species of Clematis.

Ling'ua, Pliny. L., a tongue, from the shape of the leaf; so called on the supposition that it is the "Lingua" of Pliny. "There is a herb called 'lingua' which grows in the vicinity of fountains" (Pliny's Nat. Hist.) "Fée identifies it with Scolopendrium officinarum of Willdenow, the Lingua cervina of other botanists" (note in Bohn's Ed. of Pliny) - or the Hart's-tongue Fern, which seems to be more probably the plant alluded to by the author.

Rapi'Anus, Theophrastus. G. raphanis, L. raphanus, a radish; from G. raphainein, to appear quickly, according to Fuchs, on account of its rapid germination.

Iiruphanis'trum, Ray. The same derivation as the last. "The repetition of a generic name, with the addition of 'istrum' or 'astrum' applied to a species, indicates that it is a useless or contemptible member of that genus, or bears a false resemblance to the species which comprise it." -E. B.

Rest'da, Pliny. From L. resedo, I calm; from its supposed sedative qualities. 
Lu'teola, Ray. From L. lutum, dyers' weed, or weld. Luteus means that which pertains to the plant lutum; hence rellow. Lutcolus is the diminutive of luteus, and means yellowish.

Rhun'vus, Theophrastus. G., rhamnos, Buclsthorn.

Frang'ula, Matthiolus. From L. frango, I break: a name given to the Alder Buckthorn at the time of Gerard, and up to the time of Linneus. Another name in those days was Alnus nigra, "black Aller" (Alder, still called "Owler" in Lancashire).

Rhixax'тhus, Linneus. From G. rhin, nose, and anthos, flower' from the shape of the upper lip of the corolla, which is remarkable in some species.

Cris'ta-gal'li, Dodonæus. L., crest of a cock, or cock's comb ; because, according to Pliny, "it has numerous leaves resembling a cock's comb." The English name is Cock's-comb, and the allusion is to the shape of the calyx.

Rhodícta. See under Sedun.

Rhynchos'pora. From G. rhinnchos, a beak, and spora, a seed; Beak-rush.

Ri'bes, Fuchs. Ribes was a word applied by the Arabian physicians to a species of Rhubarb (Rheum ribes), and its present application arose from a comparison of the taste of this plant with that of the fruit of our Gooseberry.

Grossula'ria, Dodonæus. L., grossus, an unripe fig. The name was applied by Linneus as the second name for the Gooseberry. The most usual name for this plant in the sixteenth and seventeenth centuries was Uva crispa. It does not appear to have been knorm to the ancients, which may be accounted for by its being " chiefly confined to cold or temperate climates, neglected in Switzerland, and with difficulty raised in 
Italy."-Smith, Eng. Fl. Dodonæus gives Grossularia as a recent name, and says the plant was more usually called Uva crispa.

Romme'ria. Named in honour of J. J. Roemer, professor of Botany at Zurich, who died there in 1819.

Ro'sa, Pliny. L. name for the liose. It appears to be derived from $r \cdot h o d d$, which in different forms is traced both in the Greek and Keltic, and signifies red, or rose-coloured.

Ru'bia, Pliny. From L. ruber, red; from the colouring properties of the genus. Rubia tinctorum supplies the Madder-root of commerce, from which is obtained the beautiful fast colour called "Turkey red," and several other colours, according to the chemicals it is brought into contact with. The colouring matter (alizarin) may be separated, in the form of brilliantly tinted needle-shaped crystals.

Ru'bus, Pling. L. name for a Bramble-bush.

Ru'sIex, Pliny. The origin of the name is doubtful; it is used by Pliny.

Aceto'sa and Acetosel'la. See Oxalis.

IIydrolap'athum, Gerard. G., lapathon, Sorrel, or Dock; Hydro-lapathum, Water-dock.

Rup'pia, Linneus. Named in honour of Heinrich Bernhard Ruppius, a German physician, and author of 'Flora Jenensis,' who died in 1719.

Rus'cus, Virgil. L. for Butcher's Broom. Gerard says it was called Bruscus in the shops.

SAGI'NA, Linneus. L., meaning meat that fattens. A name given by Linneus, but it does not seem rery appropriate to these small plants, though it has been stated that sheep are very fond of them, and that this food fattens them greatly. This seems doubtful. 
Sagitta'Ria, Lobel. From L. sagitta, an arrow; on account of the shape of the leaves.

Salicor'nia, Dodonæus. From L. sal, salt, and cornu, a horn; from the horn-like stems of the plant and its saline nature, it being one of those sea-shore plants the ashes of which consist chiefly of soda. Before soda was prepared from salt, the ashes of this and other sea-shore plants were an important article of commerce, supplying what is called Barilla.

SA'Lrx, Pliny. L. for a Willow-tree.

Arbus'cula, Linneus. L., a small tree, diminutive of arbor, or arbus, a tree. I do not know why it is generally spelt with a capital letter, or whether it should be. Linneus ('Species of Plants,' 2nd ed.) spells it with a small letter, Willdenow with a capital, Smith with a capital, and among his authorities the first is Linneus ('Lapland Flora'), Withering has a small letter; the later authorities use the capital. I cannot trace the name further back than Linneus, and I do not understand on what principle it is spelt with a capital letter.

Cap'rea or Capre'a, Limneus. From L. caper, a goat. This is not an old substantive name, so far as I can make out, nor is it spelt with a capital letter by Linneus, Willdenow, Smith, Withering, or Lindley. Why it should be by Babington, Hooker and Arnott, Bentham, in the last edition of 'English Botany,' and by Dr. Hooker' ('Student's Man.'), I cannot say. " The name caprea seems to have originated in the reputed fondness of goats for the catkins, as exemplified in the wooden cut of the venerable Tragus, their namesake."-(Smith, Eng. Fl.) This cut represents a goat standing on its hind legs, with its fore feet on the trunk of a Sallow, 
and its head stretched up as high as possible to get at the catkins, which it is eating.

He'lix, Linneus; see Hedera. I do not understand the reason of the application of this name to the Rose Willow, which is so called from the rose-like expansions at the end of its branches, caused by the puncture of an insect, which are permanent through the winter.

Myrsini'tes, Linneus. From G. myrsino-eides; Myrtlelike. This is not an old substantive name, and, as in the case of Salix arbuscula and S. caprea, there seems to have been some carelessness in the use of the capital letter, for while the Linnean school spelt myrsinites, and Bentham does the same, Hooker and Arnott, Babington, 'English Botany' and others give us Myrsinites. This must be accidental. Linneus has (Salix) myrsinites and (Euphorbia) $M$ yrsinites, but in the last instance it is the Myrtites of Pliny.

Sal'sola, Cresalpinus. From L. sal, salt; on account of the abundance of alkali yielded by its ashes (see Saticornia).

Ka'li. An Arabic name; the same as alkali (see p. 17, the Arabic article; also Salsola and Salicornia).

Sal'via, Pliny. L. for sage, from salvo, I heal; on account of its medicinal repute.

Sanidu'cus, Pliny. L. for the Elder. This name is supposed to have been given because a musical instrument called the sambuca was made of it, but I do not know what authority there is for the fact. The sambuca was a stringed instrument, and whatever musical instrument was made of the Elder was probably a wind instrument, a shepherd's horn in fact, for Pliny tells us:- "It is a belief among the shepherds that if they cut a horn, or trumpet, from 
the wood of this tree, it will give all the louder sound if cut in a spot where the shrub has been out of hearing of the crowing of the cock." Elder stems look particularly unsuitable to strain strings from, still it is pretty generally affirmed that the wood of the Elder was used to make the sambuca, and it seems probable, from what Pliny says, that it was used for some musical instrument or instruments. Perhaps colloquially the word sambuca had a more extended meaning than the stringed instrument of the classics.

$E b^{\prime} u l u s$, Virgil. L. name for the dwarf Elder, or Danewort. Sarr'olus, Pliny. "The Druids have given the name of 'samolus' to a certain plant which grows in humid localities. This they say must be gathered fasting, with the left hand, as a preservative against the maladies to which swine and cattle are subject."(Pliny). It is uncertain to what plant the name was originally given.

Sanguisor'Ba, Fuchs. From L. sanguis, blood, and sorbeo, I take in, or absorb. "Burnet is a singular good herbe for wounds, and commended of a number: it stancheth bleeding, and therefore it was named Sanguisorba, as well inwardly taken as outwardly applied."-Gerard.

Sanic'ula, Brunfels. From L. sano, I heal; because it was used as a remedy for wounds.

SAPONA'RIA, Gesner. From L. sapo, soap. "Of the great scouring qualitie that the leaues hane; for they yeelde out of themselues a certaine iuice when they are brused, which scowreth almost as well as sope."Gerard.

Sarothani'nus. From G. saroö, I sweep, and thamnos, a shrub; because it is used to make besoms. 
Saussu'rea. Named in honour of Horace Benedict de Saussure, an eminent naturalist of Geneva, where he was philosophical professor for 25 years. He was born 1740, and died 1799 .

Saxif'raga, Pliny. L. sax, stone, and frag, break; from its reputed medicinal properties, in calculus diseases; according to Théis, by analogy, from the species rooting into rocks and breaking them up.

$G e^{\prime} u m$, see the genus. The name was applied to this plant by Magnol, and by Linneus as a trivial name.

Hir'culus, Clusius. L., a little goat; name given to this plant by Clusius - "the father of forren simples" as Gerard calls him-in 1611. The French name is Eil de bouc, or goat's eye.

Scabio'sa, Brunfels. From L. scabies, for which the plant was a reputed remedy.

Columba'ria, Linneus. From L. columba, a dove. The stem-leaves resemble in their divisions the foot of a pigeon.-Théis.

Succi'sa, Fuchs. L., cut off at the lower part, in allusion to the root. This is an old substantive name, which is frequently though incorrectly spelt with a small letter. The plant was once called Succisa Fuchsii. Fuchs does not claim to be the first user of the name, for he says it is to be found in old manuscripts. It is spelt with a capital letter by Linneus.

Scan'dix, Theophrastus. G. name for some kind of Chervil, perhaps for the plant to which we now apply it.

Pec'ten, Dodonæus. L., a comb; our English name is Venus' Comb, which is the translation of the old name Pecten Veneris.

Scheuchze'ria, Linneus. Named in honour of the brothers

Scheuchzer, celebrated Swiss botanists (see p. 69). Scrre' Nus, Theophrastus. G. for a rush ; pronounced skeenus. 
Maris'cus. See under Cladium.

Scin'La, Dioscorides. G. and L. for Sea Onion, or Squill. ScIR'Pus, Plautus. L. for Bulrush; pronounced sirpus. "Nodum in scirpo quærere," to seek a knot in a bulrush, i.e., to seek a difficulty where there is none, was a L. proverb.

IIoloscho'nus, Dalechamps. G. holos, entire, and schoemus, rush.

Scleran'thus, Linneus. G. scler, hard, and anthos, a flower; from the hard nature of the floral covering.

ScLerochlo'A. G. scler, hard, and chloe, grass.

Scolopen'Driusr, Theophrastus. Said to be named from the lines of fructification resembling the feet of a scolopendra, or centipede; but the name seems to have been given originally to Ceterach, and not to the Hart's-tongue. Both Matthiolus and Gerard speak of the name Scolopendrium being incorrectly given by some to this fern, the Phylittis of Dioscorides and Lingua cervina of the shops, probably the Lingua of Pliny (see Ranunculus Lingua). The reason for the name is therefore uncertain.

Scrophula'ria, Brunfels. From L. scrofula; the roots of some species resembling scrofulous tumours, "and it is reported to be a remedie against those diseases whereof it took his name."-Gerard.

Scorodo'nia, Linneus; see also under Teucriunr. From scorodon, G. for Garlic. This plant was called by Plukenet, Ray, and others, "Scrofularia scorodoniæ folio."

ScutellaA'Ria. From L. scutella, a little dish or cup, which the calyx, with its appendage, or ear, somewhat resembles.

SE'Dus, Pliny. From L. sedeo, I sit; on account of their 
manner of squatting on rocks, walls, or roofs, with scarcely any soil.

Rhod'iola, or Rhodi'ola, Limneus. The old name was Rhodia radix, Rose-root. "Some have thought it hath taken the name Rhodia of the Iland in the Medeterranean sea, called Rhodes: but doubtlesse it tooke his name Rhodia radix, of the root, which smelleth like a Rose: in English Rose roote, and Rose woort."-Gerard. See Rosa. Rhodi, of a Rose, ola, smelling.

Tele'phium, Dioscorides. G. name for the Orpine; from Telephus, a son of Hercules, and king of Mysia.

Selaginel'́la. Diminutive of Selago, an old name for Lycopodium.

Sempervi'vuxi, Pliny. L., semper, always, anc. vivum, living. Senebie'RA. Named in honour of Jean Senebier, a physiologist of Geneva, who died there in 1809.

Coron'opus, Theophrastus. See under Plantago.

Senec'io, Pliny. From L. senex, an old man; on account of the hoary appearance of some of the species. See Erigeron.

Jacobe'a. From L. Jacobus, James; St James'-wort. Serrat'dua, Pliny. From L. serratus, saw-shaped; alluding to the margins of the leaves.

Ses'eli, Dioscorides. G. and L. name for Meadow Saxifrage.

Seste'ria. Named after Leonard Sesler, an Italian physician and botanist.

Seta'ria. From L. seta, a bristle; on account of the involucre of bristles surrounding the spikelets.

Sherardia, Dillenius. Named in honour of William Sherard, D.C.L., F.R.S., who was born 1658, at Bushby, in Leicestershire. He studied Botany under Tournefort, and travelled much on the continent. 
He was thirteen years Consul at Smyrna, and died 1728 , at Eltham, in Kent, a place remarkable for the celebrated garden of his brother James, the choice plants of which are pictured and described in the 'Hortus Elthamensis' (Eltham Garden) of Dillenius. See p. 60.

Sibbal'dia, Linneus. Named in honour of Robert Sibbald, an Edinburgh professor, who published a book on the Natural History of Scotland in 1684, with a figure of the only British species of this genus. $\mathrm{He}$ died in 1720 .

Sibthorp'sa, Linneus. In honour of Dr. Humphrey Sibthorp, the successor of Dillenius in the botanical chair at Oxford.

Sifa'Us, Pliny. A name used by Pliny, but its meaning is unknown, and there is great uncertainty as to the particular plant alluded to.

SILE'NE, Theophrastus. Supposed to arise from G. sialon, saliva, in allusion to the viscid moisture on the stalks of many species: whence, too, the English name " Catch-fly."

Arme'ria. See the genus.

Oti'tes, Smith. From G. ot, ear, on account of the shape of the leares. As a trivial name Otites was used by several authorities before Smith, but under a different generic name than Silene. Silene Otites is now the generally received name for the plant, but Otites is scarcely a substantive name, though spelt with a capital letter.

Su'ybun, Dioscorides. G. name of a kind of Thistle which was considered edible. Pliny tells us :- "In Cilicia, Syria, and Phœnicia, the countries where it grows, it is not thought worth while to boil it, the cooking of it being so exceedingly troublesome, it is said." 
Sine'turs. Named after a Sicilian nymph called Symethis. Sina'pIs, Theophrastus. G. and L. sincupi, mustard. SI'son, Dioscorides. "Sizun, signifying in Keltic a rumning brook; some of the plants formerly placed in this genus delighting in such situations."-Théis.

Amo'mum, Pliny. A name of Pliny for a plant which he describes, but it has not been decided what that plant is, though more than half a dozen have been suggested. It is not our Sison Amomum.

Sisyn'briun, Theophrastus. G. sisymbrion, Water Mint, a name also given to several other plants, probably, among the rest, to some of this genus.

I'rio, Dioscorides. G., a name used by Dioscorides.

Sophi'a, Dodonæus. G. for wisdom. Gerard calls it "Sophia chirurgorum," or the wisclom of surgeons, in allusion to the high repute of the herb for healing wounds and remedying some diseases. An absurd officinal name.

Sisyrinch'iur, Theophrastus. G. mame given to some bulbous-rooted plant.

SI'Ux, Dioscorides. G. sion, the meaning is uncertain. Gerard says of "Apium sylvestre, or Wilde Parsley" (our Marsh Hog"s Fennel, Peucedanum palustre) that "oftentimes it is named Elioselinum and Sium," almost seeming to infer that Sium is a contraction of Selinum, or Parsley. Fuchs says that it means the same as L. concussus (a shock or shaking), from G. seio, I shake; from the plant having attributed to it medicinal properties similar to those of Saxifraga, which see.

Simlaci'Na. Diminutive of Smilax, of Pliny, or Sarsaparilla. Smilax was a fabled beautiful shepherdess of antiquity, who was reported to have been changed into a plant. 
Suryr'nium, Dioscorides. From G. smyrna, the same as myrrha, myrrh; from the scent of its juice.

Olusa'trum, Gerard. From L. olus, a pot-herb, and atrum, black. Alexanders was formerly much used as a pot-herb, and received its $L$. name from the sombre colour of its foliage; in French it is called Persil noir, i.e. Black Parsley.

Sola'num, Pliny. According to some altered from L. solamen, comfort, relief or solace; from the sedative qualities of some of the species. This is doubtful.

Dulcama'ra, Dodonæus; and also formerly Amara-dulcis.

L. dulcis, sweet, amara, bitter, Bitter-sweet as we call it; because its first taste is bitter, but afterwards the sensation changes to that of sweetness.

SolidA'Go, Brunfels. From L. solidare, to make whole or "sound; it is a name that has been given to different plants, as Comfrey, Self-heal, and others, besides Golden-rod.

Virgau'rea, Matthiolus. From L. virga, a stem, branch, or rod, and aurea, golden; from the yellow racemes of flowers.

Sonch'Us, Theophrastus. G. sonchos. "According to Theophrastus the name of this genus of plants comes from G. soös, safe, and echein, to have; from its yielding a salubrious juice, but to which species this applies is not clear."-E. B.

Sparga'nium, Dioscorides. G. sparganon, a little band; from its narrow and long leaves.

Spartína. From G. spartion, of Dioscorides; Broom. Pliny mentions the name in connection with a kind of Broom, which he tells us was used for making withes; and in another part of his work he also alludes, under the same name, to what we now call Esparto, of which large quantities are at present 
imported into this country by the paper-makers. This is the Stipa tenacissima of Linneus.

Specula'ria. L. speculum, a mirror, usually of burnished metal; on account of the shape of the flowers.

SPer'gula, Dodonæus. From L. spargo, I scatter; the seeds being widely dispersed. Spergula arrensis is a troublesome weed of corn-fields.

Spergula'ria. Named from resembling Spergula.

SPIR ${ }^{\prime} A$, Theophrastus. Derivation uncertain.

Filipend'ula, Dodonæus. From L. fili, thread, and pendula, hanging; because the knobby roots of the Dropwort hang, as it were, by threads.

Ulma'ria, Dodonæus. From L. ulmus, an Elm-tree; the leaves being something like those of an Elm. Dodonæus gives Ulmaria as a common name for our Meadow-sweet, but the name that he uses is "Regina prati," i.e., Queen of the Meadow.

Spiran'thes. G. speir, a thing twisted or wound round, and anthos, flower; referring to the twisted inflorescence. Stach'ys, Dioscorides. G. stachys, a spike, or ear of corn; the name given from the general appearance of the flower spikes of these plants.

Stat'rce, Dalechamps. From G. staticos, causing to stop; having been employed from its astringent qualities to check dysentery.

Limo'nium, Dioscorides. G. It was formerly applied to the Winter-green, as well as to Sea Lavender. The G. word limonios means pertaining to a meadow, or any moist grassy place.

Stella'kia, Brunfels. From L. stella, a star; on account of the star-like form of the flowers.

Holos'tea. See Holosteunr.

Stratio'tes, Dioscorides. G. name for a soldier. The Stratiotes of Dioscorides is not our Water Soldier, 
and the name does not appear to have been so applied much before the time of Gerard, who mentions it among the names for our plant, while Lonicerus gives it to the Water Milfoil. Pliny gives an account of the Stratiotes of the Greeks, and "Crsalpinus identifies it with Salvinia natans; but Fée thinks, with Sprengel, that it is the Pistia stratiotes of Linneus, Great Duckweed or Pondweed."-Note in Bolnn's Ed. of Pliny. Whaterer the plant may have been, the name was probably given originally on account of a rulnerary property, and has been applied as at present on account of its sword-shaped leaves.

Sux'DA, Forskal. "Suced is the Arabic appellation of one of the species, all of which yield soda."-Hooker and Arnott. (See also SaLicorxia and Salsola Kali).

Subula'ria, Ray. From L. subula, an awl; the leaves being awl-shaped.

Sympн'yтur, Dioscoricles. G. name, from symphyo, I make to grow together; from its reputation for healing wounds.

Tan'Arix, Pliny. The derivation seems to me doubtful, but the following may be quoted:- " This genus of plants is named from a Hebrew word tamarik, abstertion, from the reputed qualities of some of the species for cleansing and purifying the blood, or from the fact of the branches being used as brooms. This is the derivation given by the best authorities; others say that the plant derives its name from the fact of its growing on the banks of the Tamaris, now Tambro, on the borders of the Pyrenees."-E. B. I do not pretend to estimate the comparative value of the 
writings of very high authorities, and must leave that to my readers.

Ta'nus, Gesner. Probably the uva taminia of Pliny, which name he alludes to as having been erroneously applied to another plant, but in his chapter on Black Bryony he does not use this name. He says: "For there is a black vine properly known as the 'bryonia,' though by some persons it is called the 'cheironia,' and by others the 'gynæcanthe' or 'apronia.' It differs only from the one previously mentioned" (Bryonia dioica, or White Bryony) "in its colour, which, as already stated, is black. The shoots of this tree, which resemble asparagus in appearance, are preferred by Diocles for eating to real asparagus, as a diuretic, and for its property of reducing the spleen."-Pliny Nat. Hist. Bohn. "The shoots of Tamus communis are still eaten in Tuscany as a substitute for asparagus, to which, however, they are inferior in quality. It is there known by the name of tamaro."-Note in Bohn's Ed.

Tanace'tum, Pliny. Formerly called also G. Athanasia, immortality ( $a$ not, and thanatos, death. Tanacetum, is according to Linneus an altered form of Athanasia, but it seems a rather far-fetched derivation.

Tarax'acum. See under Leontodon.

Dens-leonis, Dodonæus. L., tooth of a lion. The French name, having the same meaning, is Dent de lion, of which our name Dandelion is a corruption. The allusion is to the large teeth of the leaves.

Tax'us, Pliny. L. for the Yew-tree, perhaps from G. toxon, a bow; as the wood is an excellent material for these weapons, but the etymology of the name is uncertain. Teesda'lia, R. Brown. Named in honour of Mr. Robert Teesdale, a Yorkshire botanist, who died in 1804. 
Teu'criun, Dioscorides. Named from an ancient king of Troy called Teucer, who is said to have first employed this plant medicinally.

Bot'rys, Dioscorides. G., a bunch of grapes.

Chame'drys, Dioscorides. G. chame, on the ground, and drys, an Oak. Applied by Dioscorides to Germander.

Scor'dium, Dioscorides. G. scorodon, Garlic.

Scorodo'nia, Cordus. The same derivation as the last. The former is the Garlic germander, and the latter the Garlic sage, of Gerard.

Thalic'trun, Dioscorides. From G. thallo, I flourish, or shoot out.

The'siun, Theophrastus. Named from Theseus, a king of Athens, B. c. 1235, one of the most celebrated heroes of antiquity. Festivals and games were instituted to his memory, and these were still celebrated with their original solemnity in the age of Pausanias and Plutarch, about 1200 years after his death. Sprengel says that the Thesion of Pliny is the Thesium linophyllum of modern Botany, but from Pliny's description there seems little ground for this opinion. The G. theseion was some plant used to form the crown competed for at the games (called Theseia) just mentioned.

Thras'pr, Dioscorides. From G. thlao, I flatten; on account probably of its compressed seed-vessels.

Thrix'cla. From G. thrincos, a battlement; from the resemblance of the seed-crown of the marginal florets to the battlements of a wall.

Thy'mus, Theophrastus. G. thymos, perhaps from thyoo, I make fragrant, but the most usual derivation is from thyo, I excite; from its reputed medicinal properties; or from "thymos, the heart, from its balsamic odour 
strengthening the animal spirits." - Hooker and Arnott.

Serpyl'tum, Pliny. L. for Wild Thyme. G. name herpyllos, derived from herpo, I creep; the L. serpo, I crawl, and repo, having the same meaning, are both from this root.

T'in'IA, Pliny. L. for the Lime-tree.

TILLE'A. Named in honour of Michael Angelo Tilli, an Italian botanist, born 1655. He was Professor of Botany at Pisa, and author of 'Horti Pisani Catalogus' (Catalogue of the Pisa Garden), with fifty plates. He died at Pisa in 1740.

ToField'Aa. Named by Hudson in honour of Mr. Tofield,

a Yorkshire botanist.

Tordyu'IUM, Dioscorides. G. tordylion.

Tonm'is, Adanson. IIeaning of the name not known; probably,

like many of Adanson's names, it has no meaning. Anthris'cus, Pliny. Has been supposed to have meant cultivated Chervil.

Tragoro'gon, Dioscorides. From G. trago, goat, and pogon, a beard from the bearded fruit.

Trichour'Anes, Dioscorides. G. trichoma, a growth of hair; because it was supposed to restore the hair. "The lie wherin it hath beene sodden, or laid to infuse, is good to wash the head, causing the scurffe and scales to fall off, and haire to growe in places that are pild and bare."-Gerard. This name was not formerly given to the Bristle Fern, but to the Maidenhairs. Lonicerus tells us that "Trichomanes is Polytrichum of the apothecaries, which name is common to all species of Adiantum, as Trichomanes is also a species of Adiantum." $\mathrm{He}$ applies the name particularly to our common Maidenhair Spleenwort, and this seems to have been the 
general custom. Gerard gives two plates, the male Trichomanes and the female. The first is Asplenium Trichomanes, and the second seems to be the same. Trichone'sra. G. tricho, hair, and nema, a filament. Triexta'lis, Cordus. It is not known for what reason this name has been given. L. triens means the third part of anything, and it has been suggested by Théis that the explanation may be found in the plant being four inches high-more or less-or the third part of a foot; this is at least ingenious.

Trifo'Lrusr, Pliny. L. for clover, tri, three, and folium, a leaf; as we say trefoil, on account of the ternate leaves.

Triglo'chix, Limneus. G. tri, three, and glochin, a point; from the three points or angles of the capsules in the common species.

Trigonel'ta, Linneus. G. tri, three, and gon, angle, on account of the triangular appearance of the flower.

Trix'IA. Named in honour of Karl Bernhard von Trinius, a German botanist, author of 'Species Graminum,' \&c., who died at St. Petersburg in 1844.

Triod'sa, R. Brown. G. tri, three, and od, tooth; because the glumellas are three-toothed at the summit.

Trise'tum. L. tri, three, and seta, a bristle or stiff hair; referring to the three awns.

Trix'ıcux, Pliny. L. for wheat, from tritus, rubbed; wheat being rubbed from the ear.

Trou'Lius, Gesner. "Troll-flower, the globe-flower, from Sw. troll, Da. trold, Fris. trol, a malignant supernatural being, a name corresponding to Scotch Witches Goucun, and given to this plant on account of its acrid poisonous qualities."-Prior.

Tu'LIPA, Gesner. From an eastern name for a turban, which has been variously written Tulipa, Tulipan, and Tolibum, from some supposed similarity in the flower. 
Turri'tis, Lobel. From L. turris, a tower; the leaves becoming gradually smaller upwards, so that the plant assumes a pyramidal form.

Tussila' Go, Pliny. From L. tussis, a cough; for the cure of which the plant is still considered useful.

Far'fara, Pliny. A name which has been used in several forms for Coltsfoot, as Farfarum, Farfugium, Farfaranum, Farfarella, \&c. Pliny says:- "The Chamæluce is known amongst us as the Farfarum, or Farfugium: it grows on the banks of rivers, and has a leaf like that of the Poplar, only larger. The root of it is burnt upon cypress charcoal, and by the aid of a funnel the smoke is inhaled in cases of inveterate cough." Coltsfoot is still smoked, either by itself or in conjunction with tobacco, but Fée judiciously remarks that to inhale the smoke in the manner here described would be enough to create a cough if it did not exist before.

Tr'pHa, Theophrastus. From G. typhos, a pool; such being the habitat of these plants.

U'Lex, Pliny. A name used by Pliny for some plant which has not been certainly identified, but which may have been our Gorse. In a chapter on the finding of gold he says:- "Trenches-known as 'agogre'- -have to be dug for the passage of the water; and these, at regular intervals, have a layer of Ulex placed at the bottom. This Ulex is a plant like Rosemary in appearance, rough and prickly, and well adapted for arresting any pieces of gold that may be carried along." Ur'mus, Pliny. L. for an Elm-tree.

UR'TICA, Pliny. From L. uro, I burn; in allusion to its stinging property.

Utricula'RIA, Linneus. From L. utriculus, a little bladder ; 
on account of the little bladder's that float the plants.

Vaccin'rux, Pliny. Probably altered from L. baccinic;

denoting a plant with abundance of bacce, berries.

Myrtil'lus. From L. myrtus, a myrtle; little myrtle, on account of the form of the leaves.

Oxycoc'cos, Cordus. G. oxy, sharp, or acid, and coccos, a berry.

Vi'tis-Idce'a, Pliny. L., Vine of Mount Ida, a celebrated mountain in Troas.

Valeria'xa. Said to be from L. valeo, I am powerful; on account of its medicinal effects: others have said from Valerius, the name of several celebrated Romans. Whatever the derivation may have been the apothecaries of the middle ages seem to be responsible for it. The G. name was Phu, equivalent to our Fangh! an expression of clisgust, and to the human sense it is certainly an ill-smelling herb, though cats like it. Other names were numerous, but the name of the shops was Valeriana domestica.

Valerianel'́a, Columna. From some resemblance to Valerian, of which name it is a diminutive.

Auri'cula. L., a little ear.

Verbas'cum, Pliny. Supposed to be altered from Barbascum, from L. barba, a beard; in allusion to the shaggy nature of its foliage.

Blatta'ria, Pliny. From L. blatta, a moth, or other insect, which its leares were supposed to collect.

Lychni'tis, Linneus. From Lychrss, which see.

Thap'sus. "Thapsus has been derived from Thapsus, in Africa, near which place it is said to have formerly abounded." Tapsus barbatus was the old officinal name for Mullein. 
Verbe'Na, Pliny. Speaking of "Sagmen" and "Verbena" Pliny says: "These two names no doubt originally signified the same thing-a green turf torn up from the citadel, with the earth attached to it, and hence, when enroys were despatched to the enemy for the purpose of clarigation, or, in other words, with the object of clearly demanding restitution of property that had been carried off, one of these officers was always known as the verbenarius," - or bearer of the verbena. The etymology of the name is dubious. It has been said to be derived from Keltic ferfaen, having the same signification as Saxifraga, which see. The word verbence (L.) signified generally sacred boughs, or branches of trees that were used in religious ceremonials; hence it has been suggested that it is a corruption of the two G. words, hiera botane, or sacred plant.

Veroxíca or Verox'ica, Fuchs. A name of the middle ages, the meaning of which is very uncertain. Lonicerus tells us it is called "after some king of France, as Brunschwigius asserts." Others say that it is called after the Saint of that name, and several more derivations, rather ingenious than probable, have been suggested from the Greek, Latin, Persian, and Arabic. G., hiera, sacred, cicon, picture, seems the most likely.

Beccabung'a, Dodonreus. Changed from the German name Bachbunge (bach, a brook, and bunge, a bunch). The plant growing in brooks, in closely matted bunches.

Vinur'xur, Varro. The wayfaring tree is supposed to be the Viburnum of Virgil. The derivation of the name is uncertain.

Lanta'nu, Dodonwus. Italian name for the wayfaring tree. 
Op'ulus. A Latinised name used for the Guelder Rose in the middle ages. The French name is obier, and an English name used by Gerard, the Ople-tree, though now gone out of use, may be found in Johnson's Dictionary on the authority of Ainsworth. Théis says that Opulus was altered from Populus, the leaves being similar.

VIc'IA, Varro. Fuchs quotes Varro in giving the derivation of the name from $v i(n) c i o$, I bind, encircle, or twine about; in allusion to the tendrils of Tetches. According to Théis it is derived from Keltic gutig.

Crac'ca, Dodonæus; according to whom the plants known by this name were also called Arachus, from the G. name arachon; Cracca seems to be an altered form of the word.

Or'obus, Theophrastus. G. name for a kind of pulse.

Villar'sta. Named in honour of Dominique Villars, author (in 1786) of a Flora of Dauphiné, and other botanical works.

Vrx'cA. Pliny gives this name at full length as Vincaperrinca, and it is supposed to mean our Periwinkle. The derivation is the same as that of VIcra.

VI'olA, Pliny. L. for the Violet, and it was also used for the Wallfower and other plants: from G. Ion, of Theophrastus. "It is called Ion, according to Nicander," because certain nymphs of Ionia first presented this flower of Jore as an offering. Or, according to other's, because the earth brought forth this flower for the food of Io when she was changed into a cow."-Lonicerus.

* Nicander was a Greek grammarian, poet, and physician of Colophon, в. с. 137. His writings were held in estimation, but his judgment cannot be highly commeniled, since without any knowledge of agriculture he rentured to compose a book on that intricate subject.Lempriere, 
Vis'cunr, Fliny. L. for Mistletoe, and also for bird-lime prepared from it; from G. ixos, having the same meaning. It is said to have been originally derived from Keltic guid, the shrub; on account of the reverence in which it was held by Keltic nations.

Wahlenberg'ia. Named in honour of Göran Wahlenberg, M.D., of Upsal, who published in 1812 a 'Flora Lapponica,' and other botanical works, including an edition of Linneus' 'Flora Suecica.'

WoLF'Fia. Named in honour of J. F. Wolff, who published a work on Lemna in 1801. Wolffia is a separation or split from the genus Lemna.

Woods'is. Named in compliment to Joseph Woods, Esq., author of a 'Monograph of the British Roses,' 'The Tourist's Flora,' \&c., who died in 1864.

Xax'thiunr, Dioscorides. From G. xanthos, yellow, or fair ; because an infusion of this plant was supposed to improve the colour of the hair.

Struma'rium. An old name for the plant. It is not spelt with a capital letter by Linneus, but by the application of his rules, and his general practice, it should be. "The lesser Burre Docke is called of the Græcians, Xanthion, in Latine Xanthium: in shops, Lappa minor, Lappa inuersa, and of diuers, Strumaria."-Gerard. Struma is L. for a scrofulous tumour, and Strumus was a name given by Pliny to a species of Ranunculus used for this complaint. I cannot trace the reason for the application of the name Strumarium to Xanthium.

ZANxichel'Lia. Named in honour of John Jerome Zannichelli, a Venetian apothecary and botanist. $\mathrm{He}$ 
published a history of the plants growing in the neighbourhood of Venice, and died in 1729.

Zoste'ra, Linneus. From G. zoster, a girdle, or ribbon; which the leaves somewhat resemble.

\section{ADDITIONAL.}

I add the following names, which have been inadvertently omitted. With the exception of Draba, Galinsoga and Pulicaria, they are synonyms of genera already mentioned, which have been adopted in one or other of the four most recent standard works on the British Flora.

APE'RA. Applied to a section of Agrostis. A name given by Adanson, and probably without any meaning.

Bruver'La. The same as Prunella, which see.

CYт'Isus, Pliny. L., it is uncertain to what plant this name was originally giver. The account of Pliny describes it as a valuable fodder plant, but from the varying statements of different ancient authors, it has been supposed that two have been mixed up together as Cytisus, one of which may have been Lucerne, and the other Laburnum. It was at any rate a leguminous plant. The only British species of Cytisus is the Broom, otherwise called Sarothamnus.

Dabeo'cra. From St. Dabeoc, an Irish saint; the plant (otherwise called Menziesia polifolia) occur's as British in Ireland only.

Dra'ba. Dioscorides applies the name Drabe, or Arabis to a kind of Cress. The usual explanation is G. drabe, acrid, from the taste, which, if there is such a word having that meaning, seems plausible enough. Arabis 
is said to be derived from Arabia, but Gerard had a curious fancy that it was corrupted from Drabe:"in Greeke drabe or Arabis, by a small errour in chaunging $d$ into $a$." The Drabe of Dioscorides was not a British plant, and the meaning of the name seems doubtful.

Exprn'ion. A mythological shepherd, who, it is said, required of Jupiter to grant him to be always young, and to sleep as much as he would: whence came the saying "to sleep the sleep of Endymion," to express a long sleep. The name, botanically, is a synonym of Agraphis. Whether the sleeping propensity of Endymion had any connection with the nodding habit of this flower, I do not know.

Eroph'ILA. G. ero, spring, and phila, loving. "Usually combined with Draba, but as distinct as any genus in the Order."-Student's Flora.

EUfra'GIA, synonymous with EupHrasia, which see. In this case the name is applied to the plant called also Bartsia viscosa. Bartsia was formerly considered by some to be a kind of Eyebright, and Gerard calls it Eyebright Cow-wheat.

Fagop'rrum. See Polygonum Fagopyrum.

Galinso'GA. Named in honour of Don M. M. Galinsoga, a Spanish botanist. It is a Peruvian Composite, which is admitted into the British Flora as a colonist by Hooker and Syme. It grows chiefly about Kew.

Halos'cias. From G. halos, of the sea; a synonym of

Ligusticum. It grows on rocks by the sea.

Pulica'ria. From L. pulex, a flea; either from its being supposed to drive away fleas, or from the resemblance of the seeds to those insects. 


\section{$\S$ II.}

\section{ADJECTIVE NANES;}

WITH THEIR MEANINGS.

Those marked * are Greek, the rest are Latin.

A.

*acanthoi'des; like the Acanthus, or Bear's Breech. acau'lis; without stem. acicula'ris; pointed, or needle-shaped. From aciculus, a

little needle.

aculea'tus; thorny, or prickly.

acumina'tus; acuminate, i.e., pointed.

a'cris; acrid. Sedum acre, biting Stonecrop.

acutiflo'rus; pointed as to the flower.

acutifo'lius; pointed as to the leaf.

acu'tus; acute or pointed.

æstiva'lis; belonging to summer. From cestivus, summer,

adj.; astas, summer, sub.

æsti'vus; summer, adj.

affi'nis : allied.

agra'rius; pertaining to agri, or fields.

aggrega'tus; gathered together.

*agrosti'dea; like Agrostis, see p. 100.

*aizoi'des; like the House-leek. G. ai, ever, zoön, living, is equivalent to L. Sempervivum, which see p. 166.

al'bus; white.

al'bidus; whitish. 
*aloi'des; aloe-like.

alpes'tris; alpine, growing on lofty mountains.

alpi'nus; alpine.

alsinifo'lius; alsine-leaved. Alsine was the old name for Chickweed.

alterniflo'rus; alternate-flowered, i.c. arranged at different heights on the same stem,-not opposite.

alternifo'lius; alternate-leaved, see last.

ama'rus; bitter.

ambig'uus; obscure.

amethys'tea; bluish, or amethyst-coloured, amethystina would be more correct.

amphib'ius; amphibious.

amplexicaul'e; amplexicaul, i.e. (the leaves) embracing the

stem; amplexo, I embrace, and caulis, a stem.

ampulla'cea; bottle-shaped, from ampulla, a vessel swollen in the middle and having a narrow neck.

*amygdaloi'des; almond-like.

angula'ris; angular.

angustifo'lius; narrow leaved, angustus, narrow.

angustis'simus; narrowest.

anno'tinus; a year old.

an'nuus; annual.

*anthropoph'ora; man bearing (the man-orchis), from the resemblance of the flower.

*apet'ala; without petals.

apif'era; bee-bearing (the bee-orchis). From apis, bee, and fero, I bear; from the resemblance of the flower.

aquat'icus; aquatic, i.e. growing in or near aqua, water. aquat'ilis: pertaining to water.

aquilina; pertaining to an eagle. Pteris aquilina, Bracken, presents in the section of its root a figure which Limneus likened to the royal eagles of his native flag. 
* arachni'tes; spider-like; arachne, a spider; the late Spider Orchis (Ophrys arachnites).

aranif'era ; aranea, a spider, spider-bearing; Spider Orchis,

(Ophrys aranifera).

arbor'eus; arbor, a tree, tree-like.

arc'ticus; arctic, from G. arctos, the Great Bear, or northern constellation; the North Pole.

arcua'tus; in the form of a bow (arcus).

arena'rius; pertaining to sand (arena).

argen'teus; silvery (argentum, silver).

aromat'icus; aromatic; aroma, spice.

articula'tus; jointed; articulus, a joint.

arundina'cea; arundo-like. Arundo, a reed.

arven'sis; inhabiting ploughed fields (arrus, a field).

as'per, as'pera, as'perum; rough.

asper'sus; sprinkled.

atra'ta; clothed with black.

au'reus; golden; aurum, gold.

auranti'acum; orange-coloured. Citrus aurantiacus is the name. given to the Orange on account of the golden colour of its fruit; in this place a trivial name for one of the Hawkweeds (Hieracium).

auric'omus; anri, of gold, and coma, hair; or, as we say, Goldylocks.

auri'tus; provided with ears (auris, an ear).

austra'lis; southern.

autumna'lis; belonging to the autumn.

avena'ceum; resembling the Oat (Avena).

avicula're ; pertaining to little birds (aviculus, diminutive of avis, a bird). The name is applied to that species of Polygonum which we call Knotweed. Withering, quoting Linneus, says:- "The seeds are useful for every purpose in which those of the next species (Buckwheat) are employed. Great numbers of small 
birds feed upon them; cows, goats, sheep, horses and swine eat it. The stubbles in Swreden are purpled over with this plant."

a'vium; of birds; Bird-cherry (Prunus avium); food for birds.

axilla'ris; axillary, i.e. arising from the axil of a leaf.

B.

bacca'tus; bearing berries.

barba'tus; bearded.

bi'color; two-coloured.

bien'nis; biennial, or flowering in the second year of its growth and then dying.

biflo'rus; two-flowered.

bifo'lia; two-leaved.

biner'vis; two-nerved.

borea'lis; northern.

*brizoides ; like Briza, or Quaking-grass.

*bromoi'des; like Bromus. Brome-grass, or Oat-grass. bulbif'era; bearing bulbs.

bulbo'sus; bulbous.

$$
\text { C. }
$$

cæru'leus; blue.

cærules'cens; bluish.

cæ'sius; bluish gray.

cæspito'sus; from cespes, literally a sod cut out, or turf.

Used in botany to signify tufted, or cæspitose.

calca'reum: pertaining to lime.

campes'tris ; pertaining to a field (campus).

canes'cens; grayish.

cani'na; pertaining to a dog; as we say Dog-violet, Dogrose, \&c., signifying inferior or common. 
capilla'ris; capillary or hair-like. A name applied to a small species of Carex by Linneus; its leaves are very slender, and its fruits are fixed to hair-like pedicels.

capita'tum; headed. Applied to a kind of cotton sedge, having an almost round flower-head; coput, a head. capreola'ta; from caper, a goat. Applied to Rampant Fumitory. carina'ta ; carinated, i.e. keeled, referring to the fruit. carpinifo'lius; hornbeam-leaved. caryophylla'cea; clove-scented. castan'eus; like a chestnut. A name applied by Smith to an alpine rush, probably from its colour.

cathar'ticus ; purging, as Buckthorn and Mountain Flax. cer'nuus; bending, or looking towards the ground.

* cheiranthoi'des; like the Cheiranthus, or Wallflower. *chloran'tha; chlor, green, antha, flower; the Butterflyorchis, though its flowers are scarcely green. cicuta'rium; from cicuta, hemlock. Applied by Smith to the plant called Hemlock Stork's-bill, referring to the shape of the leaves.

cilia'ris : cilium, an eyelid, with eyelashes; fringed. cilia'ta; same as the last. circina'tus; from circinus, a pair of compasses. Applied to a form of Water-crowfoot, the outline of the leaves of which are circular.

ciner'ea; ash-coloured.

cinnamo'mea; cinnamon. Name given to a Rose, Cinnamon Rose.

clandesti'na; hidden, concealed. Name given to a little sedge, which is "remarkable for the few flowers of its fertile spikelets, which are concealed by the comparatively large membranous sheaths, as the short stems are by the leaves."-Hooker and Arnott. 
clava'tum; from clara, a branch or club. Applied to a branching Lycopodium, or Club-moss.

clavicula'ta; clavicula, a tendril; provided with tendrils. cœno'sus; muddy. colli'nus; pertaining to a hill. columbi'nus; pertaining to or resembling a dove. commu'nis ; common. commuta'tus; changed. como'sus; hairy. compres'sus; compressed. conglomera'tus; gathered into a ball. con'icus; cone-shaped. *conop'sea; from conops, a gnat. coralli'na; red coral. I suppose in reference to the colour of the seeds.

corda'ta; heart-shaped.

cornicula'tus; bearing little horns. corylifo'lius; hazel-leaved (Corylus). corrmbo'sus; corymbose, i.e. the kind of inflorescence represented in the Pear, where a number of flowers form an even head, though the flower-stalks are of different lengths, rising from different parts of the stem.

cris'pus; crisped, or curled.

crista'tus; crested.

*crithmoi'des; like Crithmum, or Samphire. croca'tus; saffron-coloured. cur'tus; shortened.

cuspida'tus; from cuspis, a lance, i.e. pointed in the manner of a lance, broad at the base and narrowing to the summit.

D.

*dasyphyl'lus ; thick-leaved. 
* daucoi'des; like the Daucus, or carrot.

decol'orans; becoming deprived of colour.

*deltoi'dea; delta-like, or triangular.

demer'sus; immersed in water.

denta'tus; dentate, i.e. toothed.

denticula'tus; denticulate, i.e. finely toothed.

den'sus; dense, set close.

depaupera'tus; impoverished, starved.

digita'ta; digitate, i.e. like the fingers in arrangement. dilata'tus; spread out.

*dioi'ca; literally two habitations (di-oica). Diceious plants, or such as have the male flowers on one plant, and the female on a different one.

dissec'tus; cut asunder.

dis'tans; standing apart.

* dis'ticha; from dis, double, and stichos, a row or line diur'na; (flowering in) the daytime. Thus Lychnis diurna is contrasted with $L$. respertina, which flowers in the evening:

divi'sus; divided.

divul'sus; torn asunder.

domes'ticus; pertaining to a house (domus), cultivated. du'bius; doubtful, or obscure.

dumeto'rum; (growing) among bushes (dumeti).

\section{E.}

ebractea'tum; ebracteate, i.e. without bracts or floral leaves.

*echinoi'des; like an echinus, or hedgehog. ela'tior; higher, more elevated. ela'tum; similar to the last. Hypericum elatum is not a British plant, though it finds a place in some of our Floras. 
elonga'ta; elongate, lengthened, extended. ensifo'lia; from ensis, a sword, sword-leaved. erec'tus; erect. ericeto'rum; of, or pertaining to, heaths.

* erioph orus; wool-bearing. excel'sior; higher, comparative of excelsus. This name is applied to the Ash (Fraximus excelsior), one of our finest forest trees; it is given by Bauhin, and probably refers to the height of the tree.

exig'uus ; small, mean.

exim'ius; uncommon, rare, extraordinary. exten'sus; stretched out, extended.

F.

falca'tus; falcate, i. e. sickle-shaped. farino'sus; mealy, like the Bird's-eye Primrose. fastigia'tus; becoming pointed. It is a name given, for instance, to the Lombardy Poplar, and refers to the form of the tree.

fat'uus ; foolish, silly, or wild, as we say Ignis fatuus, wild fire, or Will o' the Wisp.

ferrugin'ea; the colour of iron rust. ficifo'lium; fig-leaved (fici, of a fig; folium, a leaf). filifor'mis; filiform, i.e. thread-shaped (fili-formis). fis'sus; cleft. fistulo'sus; fistulose, i. e. hollow or pipe-like. From fistula, a hollow reed.

fla'vus; yellow. flaves'cens; yellowish. flexuo'sus; flexuose, i. c. bent in alternate directions. fluitans; floating, on water. fluviat'ilis; pertaining to river's. fœ'tidus ; stinking. 
fœtidis'simus ; most stinking.

fonta'na ; (growing) about fountains, or springs.

fragif'erum; strawberry-bearing. The Strawberry Clover in fruit is much like strawberries.

frag'ilis ; fragile, brittle.

frutico'sus; fruticose, i.e. shrubby; frutex, a shrub.

fruticulo'sus; a little shrubby, suffruticose.

ful'vus; tawny.

fu'cus; red, derived from the name of a Lichen (fucus) which was used as a red dye and as rouge for the cheeks.

fus'co-a'ter; dark black.

G.

galericula'ta; provided with a small skull-cap. Much the same meaning as Scutellaria, which see.

gemmip'ara; producing leaf-buds.

genicula'tus; jointed, knotted.

* geranoi'des; geranium-like.

gib'ba; gibbous, i.e. having a swelling at some part of the surface.

gigan'tea; gigantic.

gla'bra; glabrous, i.e. smooth, without hairs.

glandulo'sus; having a remarkable supply of glands.

*glau'ca; glaucous, i.e. bluish gray, used to express the

bloom which covers the leaves of many plants.

globo'sus; globose, i.e. spherical, or globular.

globulif'era; globule-bearing.

glomera'tus; formed into a ball.

glutino'sus; gluey, sticky.

* glycyphyl'lus; sweet-leaved.

grac'ilis; graceful, slender.

gracilen'tem; of graceful habit. 
grandiflo'ra ; large-flowered.

grandifo'lia; large-leaved.

gramin'eus: grassy.

granula'tus; granulated, having granules. In Saxifraga granulata the reference is to the roots.

grav'eolens; heavy-smelling.

gutta'tus; spotted. From gutta, a drop.

H.

hasta'tus; from hasta, a spear, hastate, i.e. spear-headed. hedera'ceus; ivy-like.

hederæfo'lius; ivy-leaved.

herba'ceus; herbaceous. Salix herbacea, the herb-like Willow; from its small size.

*heterophyl'lus ; differently-leaved, as a species of Potamogeton (Pondweed).

*hexan'dra; hexandrous, i.e. six-stamened.

hirci'na; goat's.

hirsu'tus; hirsute, i.e. covered with long stiff hairs.

hir'tus; rough, hairy.

his'pida; hispid, i.e. covered with long, very harsh hairs.

*holoseri'cea ; entirely silken. Name given to a Willow, with reference to the flower.

hordeifor'mis; barley-shaped.

humifu'sa; ground-sprawling.

hu'milis; lowly.

hy'bridus; hybrid.

hyema'lis; belonging to hyems, winter.

*hyperbo'rea; arctic, literally beyond Boreas, or the north, that is the extreme north. The Hyperboreans were a supposed people in the extreme north.

*hypnoi'des; like hypnum, or moss.

*hypoglot'tis; hypo, under, and glotta, tongue. A name 
given by Linneus to a kind of Milk-vetch. I cannot trace his meaning. hyssopifo'lium; hyssop-leaved.

\section{I.}

imbrica'tus; imbricate, i.e. arranged one over another, like the slates of a house-roof.

impa'tiens ; impatient.

inca'nus; gray, hoary.

incarna'tum; this name is given to a species of Trefoil, but its meaning is not very apparent: it might mean fleshy, or not fleshy, or reddish coloured, or producing flesh, being a valuable fodder plant. Trifolium incarnatum is called in English "Crimson Clover," but the flowers are not always crimson; indeed one of its synonyms is "Trifolium album incarnatum spicatum." It is not an indigenous British plant.

inci'sum; cut into.

incur'va ; curved, bent, or bowed.

infes'ta; troublesome.

infla'ta; inflated (as the calyx of Bladder-Campion).

inna'ta; innate, inborn. I do not trace the exact application; the name is given to an orchid called Corallorhiza, of which the spur is adnate, or growing to the ovary.

ino'dora; not scented.

interme'dius; intermediate.

interrup'ta; interrupted.

inunda'tus; inundated, as growing in a marsh.

involu'ta; literally, turned inwards or involved, hidden, intricate, obscure. Name given by Smith to a kind of Rose.

irrig'ua; wet, soaked. 
J.

jun'ceum ; juncus-like.

L.

lacinia'ta; laciniated, i.e. irregularly cut uí into narrow segments.

lacus'tris; pertaining to lakes.

læviga'ta; smooth, free from roughness. From levis, "erroneously lavis" (White).

læ'vis; see the last.

*lamprocar'pus ; bright-fruited.

lana'tus; woolly.

lanceola'tus ; lanceolate, i.e. lance-shaped.

lapathifo'lium; Dock-leaved.

*lasiophyl'lum; shaggy-leaved.

*lathyroi'des; Lathyrus-like.

latifo'lius; broad-leaved.

lax'a ; slack, loose, not rigid.

ledifo'lium; Ledum-leaved (Ledum, Labrador 'Tea, cultivated in our gardens).

lendi'gerum; nit-bearing, Nit-grass. Lens means both a nit and a lentil.

lepori'na ; pertaining to a hare (lepus); Hare's-foot Carex. lingula'tum; (lingula, a little tongue) lingulate-leaved (Hawkweed).

limo'sa; muddy.

linariæfo'lia ; linaria-leaved (Linaria, 'Toad-flax).

linic'ola; from Linum, Flax. A name given to a species of Rye-grass, from some resemblance.

linophyl'lum; flax-leaved.

littora'lis; pertaining to the shore. 
loba'tum; lobed.

lolia'cea; lolium-like; Lolium, Darnel.

longifo'lia; long-leaved.

lu'cens; shining.

lu'cidum; shining, bright.

lupuli'na; pertaining to a wolf. The meaning I do not clearly understand. It was applied by Linneus to a species of Medick (Black Medick). The meaning may be like the Lupulus. See Lupulus, under Hundeus, p. 134.

lu'teo-al'bum; yellow-white.

Iu'teus; yellow.

\section{M.}

*macrorrhi'zus; great-rooted.

macula'tus; spotted.

mag'nus; great.

maja'lis; (maialis) belonging to May. May is the month dedicated to Mraia, of Greek mythology, who was the daughter of Atlas, and the mother of Mercury. The spelling with $i$ or $j$ is very much according to fancy. Some spell Apuleius, Apulejus; Leucoium, Leucojum; John, Iohn-pronounced in the German, by the way, (Johan) Yohan; and the corresponding Arabic name $\mathrm{Ja} \mathrm{ja} \mathrm{(German} \mathrm{fashion)} \mathrm{is} \mathrm{spelt} \mathrm{in} \mathrm{England} \mathrm{Yah} \mathrm{ya.}$

ma'jor; greater.

ma'jus; greater.

margarita'cea; pearly, margarita, a pearl.

mari'nus; marine.

marit'imus; belonging to the sea.

mas'cula; male.

max'imus; greatest.

me'dius; middle. 
*micran'tha; small-flowered.

milita'ris; military, the Military Orchis, on account of some resemblance in the flower to a helmet.

min'imus; smallest.

mi'nor; less.

mi'nus ; small.

mi'te; mild, pleasing, gentle, agreeable.

mol'lis; soft.

monta'na; pertaining to mountains.

moscha'tum; musky.

mucrona'tus; from mucro, a sharp point, mucronate, i.e. as

a botanical term, a stiff point, abruptly terminating an organ.

multicau'lis; many-stemmed.

mura'lis; mural, i.e. pertaining to walls.

murica'ta; from murex, a fish armed with sharp prickles, muricate, i.e. covered with firm short points or excresences.

muri'num; (from mus, a mouse), murinus, mouse-like.

Applied to Hordeum (murinum) Way-Bennet, in reference to its spike, or it might be referred to murus, a wall; for the plant grows both by waysides and on walls.

muro'rum; of or belonging to walls. muscif'era; from musca, a fly, fly-bearing, the Fly Orchis. muscoi'des; from muscus, moss; moss-like. The termination oides is Greek, but muscus is Latin. Smith strongly condemns such hybrid names.

N.

na'na; dwarf.

na'tans; swimming.

nemora'lis; pertaining to a grove. 
nemoro'sa; pertaining to a grove, but not so good a name as the last, for the strict meaning is (a country) full of groves. I use the word grove in preference to wood as a distinction between nemorosa and sylvatica, though we call Anemone nemorosa, Wood Anemone.

nem'orum; of groves.

ni'ger, ni'gra, ni'grum; black.

nigres'cens; blackish.

nigritel'lus; literally black earth, or black country, but applied to a species of Rush called the Black-headed Jointed Rush.

ni'tens ; shining.

ni'tidus; shining, or luxuriant.

niva'lis; pertaining to snow. Applied, for example, to a beautiful Alpine Gentian.

no'bilis; noble, excellent, superior. noctiflo'ra; night-flowering. nodiflo'rus; flowering at the nodes. The node, as a botanical term, is that part of a stem from which a leafbud proceeds. The word noclus means knot, and thus stems may be said to be divided into varying lengths by nodes, knots, or joints.

nudicau'lis ; naked-stemmed.

nudiflo'rus; naked-flowered. Well applied to plants which flower at times when the leaves have disappeared, or have not yet grown, as autumnal Crocus, and our garden Yellow Jasmine.

nu'tans; nodding.

*nymphæoi'des; Nymphæa-like. Nymphæa, Vater-lily.

O.

oblon'gus ; oblong.

obtusiflo'rus; blunt-flowered. Thus there are contrasted

Juncus obtusiflorus and J. acutiflorus. 
obtusifo'lius; blunt-leaved.

*ochroleu'cum; literaily pale white, which is a colour I hare no certain idea of: it is applied to the sulphurcoloured Clover. Say cream-coloured.

*octopet'ala; eight-petalled.

odora'tus; (sweet-) smelling.

officina'lis; officinal, or sold in shops.

olera'ceus; garden-stuff, pot-herb, culinary regetable. ol'idum ; ill-smelling.

ophioglossifo'lius; ophioglossum-leared, or haring leares like the Adder's-tongue (fern).

oppositifo'lium; opposite-leaved.

orienta'lis; eastern.

ora'ta; ovate, oral, or egg-shaped. From orum, an egg. ori'na; pertaining to a sheep (oris), Sheeps' Fescue-grass.

P.

palles'cens; rather pale.

pal'lidus; pale.

palu'stris ; pertaining to a marsh.

paludo'sus ; marshy.

panic'ea; like Panicum, or Panic-grass.

panicula'ta; paniculate, i.e. bearing panicles. A panicle in

Botany is that manner of inflorescence, or bearing flowers, of which we have striling examples in Oats and Quaking Grass; but though principally used in application to Grasses, it is used also for any branched raceme. (See racemosus.)

paradox'a ; paradoxical; applied to a dubious Carex that puzzles the botanists.

parvifo'lia; small-leaved.

par'vulus; tiny. 
pat'ulus; standing open.

pauciflo'rus; few-flowered.

pectina'tus; pectinate, i.e. divided in the manner of a pecten, or comb.

peduncula'tus; pedunculate, i. e. provided with peduncles. A pedicel is a flower-stalk carrying a single flower, and where such is the case the plant is called pedicellate. A peduncle is the general flowering axis which usually bears several flowers, attached to pedicels.

pen'dula; hanging.

* pentan'dra ; pentandrous, i.e. having five stamens.

"peploi'des; peplus-like. See Euphorbia Peplus.

peren'nis; perennial.

perfolia'tus; perfoliate, where there are opposite leaves united at the base, so that the stem appears to pass through the leaf. This is illustrated in Chlora, and in one of the Claytonias, which is rapidly spreading in our country, both of them having the trivial name perfoliata.

perfora'tum; perforate; applied to a species of St. John'swort (Hypericum). If you hold a leaf of it up against a good light, you observe what look like holes or perforations. These are really glands: they are well illustrated in the Myrtle family.

*petræ'a ; (growing in) rocky (places).

persicifo'lia ; peach-leaved (persicum, a peach tree).

phæ'um ; purple.

phœni'ceum; purple-red.

phylicifo'lia; phylica-leaved. Phylica, a plant of the

Buckthorn family, grown in gardens.

pilo'sus; pilose, i.e. hairy.

pilulif'era: pilule-bearing. Alluding to the fructification.

$E x$. Urtica pilulifera; Carex pilulifera, \&c. 
pimpinelloi'des; pimpinel-like. Hybrid name; see muscoides.

piperi'ta; (piper, pepper) peppery. Alluding to a species of Mentha-Pepper-mint.

planicul'mis ; flat-stemmed.

plantagin'eus; like Plantago, or Plantain (as to the leaves).

* platyphyl'la; broad-leaved.

plica'tus; plicate, i.e. folded like a fan. From plico, to fold.

poet'icus; poetical, one of many senseless names: Narcissus poeticus, "poet's" (or more correctly poetical) Narcissus. Though it has little to recommend it, the name was given by Linneus.

polifo'lia ; polished-leaf.

*polyrhi'za ; many-rooted.

*polysper'mum ; many-seeded.

porrifo'lius ; leek-leaved (porrum, leek).

portulacoi'des; purslane-like.

præ'cox; precocious, or early ripe.

prælong'us; very long.

praten'sis ; pertaining to a meadow (pratum).

*prenanthoi'des; prenanthes-like.

procum'bens; procumbent. As a botanical term, lying on the ground.

pro'lifer; proliferous, i.e. that produces abnormal buds. Ex. Dianthus prolifer, childing or proliferous pink. pubes'cens; pubescent, i.e. covered with short and soft hairs.

pulchel'la, pronounced pulleella; pretty. pul'cher, pul'chra, pul'chrum; beautiful. pulica'ris; pertaining to, or resembling, a flea. Fleacarex, a name given by Limneus in reference to the seed. 
pulverulen'tus; pulverulent, i.e. covered with dust, or powder (pulvis).

puncta'tus; punctated, dotted. Ex. Carex punctata, dotted fruited Sedge.

pun'gens ; pungent.

purpu'reo-cæru'leum; purplish-blue.

purpu'reus ; purple.

pusil'lus; very small, insignificant.

Q.

quadrang'ulum; four-cornered.

R.

racemo'sus; from racemus, a bunch or cluster of grapes, racemose, i.e. bearing racemes; the kind of inflorescence exemplified in the currant, where the main flowering axis throws off a succession of flowers.

rad'icans; rooting, as Trichomanes radicans, of which the creeping rhizome is continually throwing out roots, which fix the plant firmly to the stones about waterfalls.

radica'ta ; rooted, especially when roots are remarkably long.

Ex. Hypochæris radicata; long-rooted Cat's-ear. ramo'sus; ramose, i.e. branched. ranunculoi'des; Ranunculus-like. A G. termination to a L. name; see muscoides. rapunculoi'des ; Rapunculus-like; (Rapunculus, Rampion.

See Campanula Rapunculus).

rariflo'ra; few-flowered.

reclina'ta; reclined; spreading on the ground.

reflex'um; bent back.

remo'tus; distant, as are the spikelets of Carex remota, \&.c. re'pens; creeping. 
rep'tans ; creeping.

reticula'ta, from reiculum, a little net; reticulated, or finely netted; as may be observed in the veining of any leaf of a dicotyledonous (or two seed-leaved) plant if held to the light.

rhamnifo'lius; Rhamnus- or buckthorn-leaved. rig'idum; rigid, stiff. Ex. Aspidium rigidum, or Lastrea rigida.

ripa'ria, from ripa, the bank of a stream; pertaining to the banks of streams.

rivula'ris, rivulus, a small brook; pertaining to small brooks.

ro'seus; rose-coloured.

rosmarinifo'lia; rosemary-leaved.

rotundifo'lius; round-leaved.

rubel'la; reddish.

ru'ber, ru'bra, ru'brum; red.

rubigino'sa; the colour of rust. A name given by Linneus

to a species of Rose, from the rusty appearance of the leaves.

rudera'le, from rudus, rubbish; pertaining to old rubbish of buildings, as plaster, broken stones, \&c. rufes'cens; reddish.

ru'fus; red.

rupes'tris, from rupes, a rock; pertaining to rocks.

S.

sacchara'tus; sugary. (Saccharon, sugar, of Dioscorides and Pliny.)

sagittifo'lia; arrow-leaved; sagitta, an arrow.

salicifo'lia; Salix-leaved. (Salix; willow.)

salig'na; willow-like, given to a species of Lactuca (or lettuce), having narrow leaves. 
sanguina'lis ; causing effusion of blood, sanguis. sanguin'eus; blood-coloured, applied to different plants and different parts of them; Rumex sanguineus, in reference to the leaves; Cornus sanguinea, the twigs; Ribes sanguineum, the flowers.

sati'vus; cultivated, from sero, satum, to sow, plant, or propagate.

saxat'ilis; pertaining to rocks.

sca'ber, sca'bra, sca'brum; scabrous, i.e. rough, covered with very stiff short hairs.

scelera'tus; wicked; applied to the celery-leaved crowfoot (Ranunculus) on account of the extreme acridity of its juices. I have known celery-leaved to be taken for the literal meaning of sceleratus, on account of the similarity in sound; an odd, though not unnatural mistake, which may at least serve as an aid to the memory.

scopa'rius; from scope, thin twig-hence the name was also used for besoms; and scoparius means fit for making besoms. We mean the same thing in speaking of broom-tree, as though we said besomtree.

scutella'ta; salver-shaped; (Veronica) scutellata, alluding, I suppose, to the capsule of two flattened orbicular lobes.

secali'nus; secale-like; not our sealsale, but the se-ca-le of Pliny, which means Rye. It was a name given by Smith to a species of Carex, which is also called hordeiformis, or barley-shaped.

secun'da; flowers turned in one direction, as in a species of Wintergreen (Pyrola). This apparently curious use of a word, which we should naturally take to mean only second, is explained by its derivation sequunda following either in rank, or order). 
sedoi'des; Sedum-like.

seg'etum; pertaining to corn-fields, or segetes.

selaginoi'des; Selago-like. See Lycopodium Selago. sem'idecan'drum; half ten-stamened.

sempervi'rens; ever-green.

se'pium; of hedges, as Convolvulus sepium, growing in hedges.

septangula're; seven-cornered.

septentriona'le; northern. The word refers to the seven

(septem) stars in the constellation of Charles' Wain, or the Great Bear, situate in the northern part of the heavens.

sero'tina; late in season.

serpyllifo'lia; Serpyllum-leaved. See Thymus Serpyllum. seta'cea, from seta, a bristle; bristle-like.

sexangula're; six-cornered.

sim'plex; simple.

sinua'ta, from sinus, a fold, or hollow; sinuate, i.e. with

wavy margins of the leaves.

sol'idus; solid; not hollow.

solstitia'lis; belonging to the summer solstice.

somnif'erum; sleep-bearing, as for instance the Poppy

yielding opium. (Somnus, sleep; fero, bear).

*sphæroceph'alum; round-headed; sphaira, a ball; cephale, a head.

spica'ta; spicate, i.e. bearing flowers in spikes. A spike is that kind of inflorescence which consists of numerous flowers sessile on the axis of growth, as for instance, the common Plantain. Spica was an old substantive name for Spikenard (called Spica indica) and also for Lavẹnder.

spinosis'sima; most thorny; well applied to the little

Burnet Rose, with its innumerable prickles. spino'sus; thorny, or prickly. 
spu'rius; not genuine.

squal'idus; squalid, inelegant, ugly.

squarro'sus; squarrose, i.e. covered with processes spreaciing at right angles, or in a greater degree. Juncus squarrosus.

stagni'na; pertaining to stagnant water. Viola stagnina, inhabits bogs and fens.

stella'ris; starry, Saxifraga stellaris, stella, a star.

stella'tum; arranged like a star.

stellig'erum; star-bearing.

stellula'ta; arranged somewhat like a star.

ster'ilis; barren.

stipula'ris; remarkable as to the stipules. Stipules are those appendages at the base of the leaf-stalks which are like little leaves. In many plants they are wanting; in some they are small, in others large, while in some cases they supply the place of leaves altogether, as in Lathyrus Aphaca, which has no true leaves, but large stipules, the leaves being represented by tendrils only.

stria'tuin; streaked.

stric'tus; growing erect, conspicuously.

strigo'sus; strigose, i.e. covered with rough, strong, adpressed hairs.

suberec'tus; not quite erect, but nearly; sub, under, or slightly erect.

subero'sa; suberous, i.e. of a corky texture (from suber, the cork oak).

submer'sum; submerged.

subterra'neum; subterranean; applied to a species of Tre-

foil, on account of a peculiarity in the ripening of its fruit, a description of which may be found in all hand-books.

subula'ta, from subula, an awl; subulate, i.e. awl-shaped. 


\section{succi'sa. See Scabiosa Succisa.}

succisæfo'lia; succisa-leaved.

suffoca'tum; suffocated, applied to a small 'Trefoil.

supi'num; supine, or lying on the back; a name given to the dwarf Cudweed (Gnaphalium) by Linneus.

sylvat'icus; pertaining to a wood, silva.

sylves'tris; living in woods. Silva is accounted more correct than sylva, though botanically sylva is the more usual form; yet we have Evelyn's "Silva," a discourse on Forest trees.

* sys'tyla; styles united; mame given to a kind of Rose : the two Greek words are sy(n), together; and stylos, a column.

\section{T.}

tanacetifo'lia; tanacetum, or tansy-leaved. taraxacifo'lia; taraxacum, or dandelion-leaved. tecto'rum; of roofs. temulen'tum; drunken, with reference to the effects. tenel'la; rather slender. tenuiflo'rus; slender-flowered. tenuifo'lius; slender-leaved. ten'uis ; slender. tenuis'simum ; most slender. *tephrosan'thus, from tephra, ashes (sprinkled over the head and clothes in token of grief); and anthos, flower, or ash-besprinkled flower; a name well given to the Monkey Orchis, from the prevailing ash-colour of its flowers.

teretius'cula; rather terete, i.e. rounded; applied to a kind of Carex, of which the straw is roundish, most of the sedges having three-cornered stems. terres'tre; pertaining to the land. 
*tetrag'onum; four-kneed, or cornered.

*tetran'drum; tetrandrous, i.e. four-stamened.

*tetrasper'ma; four-seeded.

thapsifor'me; thapsus-like. See Verbascum Thapsus.

thyrsiflo'ra; thyrsus-flowered, i.c. having the kind of inflorescence called in botany by that name. It is represented in the flower-bunches of the Lilac, where the flower-stalks in the middle of a dense panicle (see paniculatus) are longer than those at the extremities. The meaning of thyrsus in Latin is the stem of a plant, and it was used to signify a staff entwined with Ivy and Vine-shoots carried about at the feasts of Bacchus.

tincto'ria; used as dye-stuff.

tormina'lis; useful for tormina, gripes or colic; applied to the wild Service-tree (Sorbus), the fruit of which was used formerly for complaints of the bowels, and generally supposed by Gerard and others to be the Sorbus torminalis of Pliny.

tomento'sus; tomentose, i.e. covered with an entangled cottony down; tomentum means stuffing for cushions. *trachyod'on; throat-toothed; a horse-tail (Equisetum), to which the name is given, being remarkable for the teeth of its sheaths.

trem'ula; shaking, quaking, tremulous.

*trian'drum ; triandrous, i. e. three-stamened.

*trichoi'des; hair-like.

tri'color; three-coloured.

tricor'ne; three-horned.

"tridacty'lites; three-fingered, alluding to the divisions of the leaves of the little Saxifrage to which the name is given.

tridenta'tus; three-toothed.

tri'fidus; thrice-cut. 
triglu'mis; three-glumed. A glume is the covering of the reproductive organs of the spikelets of grasses.

*trigy'num; three-pistiled.

triner'vis; three-nerved.

triparti'tus; thrice-divided.

* triphyl'lus; three-leaved.

triquet'rus; three-cornered.

trisul'cus; three-cleft (or furrowed).

trivia'lis; trivial, common.

tubero'sus; tuberous.

U.

uligino'sus; growing in marshy places, uligines.

umbella'tus; umbellate, i.e. the kind of inflorescence illustrated by the Carrot, Angelica, Sweet Cicely, \&c., where several stalked-flowers proceed from one point, so as to resemble an umbella, little shade, parasol, or umbrella.

umbro'sus; growing in shady places.

undula'tus; undulate, wavy.

uniflo'ra; one-flowered.

uniglu'mis; single-glumed. See triglumis.

urba'num; literally belonging to the city or town; but by metonymy having several other meanings, as polished, cultivated, urbane, \&c. Its application to Geum was some fancy of Linneus', that I do not quite understand.

ur'bicum. See last. In this case the trivial name is applied to the upright Goosefoot (Chenopodium), which grows chiefly on dung-hills and among rubbish. A name of Linneus'.

u'rens ; burning, stinging.

usitatis'simum; most common, or ordinary; well applied to the flax of commerce (Linum). 
ustula'tus; scorched. The pretty Orchis ustulata is so called, because the flowers are first dark above and white below, presenting the appearance of having been scorched.

\section{V.}

va'gans; wandering:

vagina'tus; sheathed, vagina, a sheath.

variega'tus; variegated.

verna'lis; pertaining to spring, ver.

ver'nus; spring, adj.

versic'olor'; of varied colour, or changing colour, as in the case of Myosotis versicolor.

verticilla'tus; verticillate, i.e. arranged in verticils, or whorls, from verto, I turn; thus, vertex, a whirlpool.

vesicárius; like a resicus, or bladder; thus Carex vesicaria

has its fruit broadly ovate, inflated.

vesperti'na; belonging to the evening; flowering then. villo'sus; villous, i.e. covered with long, soft hairs, and having a woolly appearance.

vimina'lis; suitable for making baskets, as the osier.

vinea'le; pertaining to vineyards; a habitat very commonly given for species of Allium. Allium vineale, literally vineyard-leek, we call in English Crowgarlic, for we have no vineyards, but on the continent they occupy a good deal of ground.

viola'ceus; violet-coloured.

vi'rens; green and flourishing.

virga'tus; virgate, i.e. long and straight like a wand (virga).

vir'idis ; green.

viro'sus; full of poison.

visca'rius; viscous, sticky, like bird-lime. 
visco'sus; the same as the last.

vulga'ris ; common.

vulga'tus; commonly or generally known.

vulpi'nus; fox-coloured, vulpes, a fox.

\section{Z.}

zosteræfo'lius; zostera-leaved (zostera, grass-wrack); trivial name for a kind of Pond-weed (Potamogeton). 


\section{APPENDIX.}

ON looking over the first part of this work there seems to be too slight notice taken of some old English botanists whose names are well known, and whose books are continually quoted. Though they may not have much to do with plant-nomenclature, and have therefore been very briefly treated of, they have been of considerable service to Botany in England. I allude especially to Turner, Gerard, Johnson, Parkinson, and Evelyn, each of whom was remarkable for something original, which has served as a basis for others to work upon and improve. Thus, Turner wrote the first 'English Herbal' worthy of the name. Gerard introduced Physic-gardens, and originated the cultivation of the potato in England, besides writing the most popular of Herbals. Johnson commenced "Local Floras," the compilation of which has done such good service in giving us knowledge of the plants of our country. Parkinson was the earliest writer in England on gardens, for flowers, culinary vegetables and fruits; and he introduced garden-rhubarb into England. Lastly, Evelyn wrote for us a book on forest trees, which has perhaps done more for their culture in this country than any other work, either before or since his time. We may say of these five botanists that they form the fountain-head of popular botany in England: they instruct us about field-botany, medicalbotany, physic-gardens, flower-gardens, kitchen-gardens, fruit-gardens, and timber. We may still gather from them 
much valuable and interesting information, which cannot be had from any other source; and if we remember what scanty accounts had been previously published of British plants, and plants that were commonly cultivated in this country, we cannot but admire their great knowledge of them, gained by direct observation, as well as their industry and learning. I therefore add a few notes on these old writers, and also a few others of matters that I had either overlooked or that have recently come to my knowledge, in the hope that they may not prove without interest. I am much indebted for several of these notes to a very interesting "Sketch of the progress of botanical investigation in Middlesex, with liographical notices," appended to the 'Flora of Middlesex;' by H. Trimen, MI.B., and WV. T. Dyer, B.A.; and also for some fresh records of Gerard and Parkinson to articles in the 'Journal of Horticulture' about these old Herbalists.

\section{'The Grete HerbaL.'}

"Several editions were indeed published, but without improvements; that of 1526 is the best known. We have seen copies dated 1526, 1529, 1539 (without figures). One is said to have appeared so late as 1561." ("Flora of Middlesex.') I have a tolerably complete copy of the edition of 1561 , which has no figures excepting two fanciful ones,'Mandrake the male,' and 'Mandrake the female.'

\section{Wilitait Turner.}

I add a few notes about William Turner, who is known as the "Father of British Botany."

Living in the disturbed reigns of Henry VIII., Edward VI., Mary, and Elizabeth, and being a clergyman who took a lively interest in the religious controversies of the time, Turner alternately lived in England, with high preferments, 
and on the continent, where he had to take refuge from persecution. He was elected a Fellow of Pembroke Hall in 1530, and held the same fellowship in 1538. About this time he became Latimer's disciple, embracing with enthusiasm the principles of the Reformation; and about 1540 he left Cambridge, and travelled about England preaching. In consequence, probably, of refusal to subscribe to the 'Six Articles,' was imprisoned for some time; and, on his release in 1542, he was obliged to leave England, to which he did not return until after the death of Henry VIII. During his absence he devoted much time to Botany, and became intimate with the great naturalist Gesner, and other eminent men. He also took the degree of M.D. at Ferrara.

On his return to England in 1547, Turner seems to have been in high farour, for the new ling made him a Prebend of Tork and Canon of Windsor; the Duke of Somerset, Lord Protector, appointed him his physician; and the University of Oxford granted him the degree of M.D. on his appointment. In 1550 he was made Dean of Wells. He was also a member of the House of Commons. On the death of the king and the accession of Mary, Turner had again (1553) to take refuge abroad, and did not return to England until after her death. Queen Elizabeth restored to him all his church preferments, and in 1563 presented him to the rectory of Wedmore, in Somersetshire. The latter years of his life appear to have been spent at Wells and in London, where he had a house 'in the crossed Fryers.' He died on July ith, 1568, and was buried on the 9th, in the south-aisle of St. Olare's, Hart Street, Crutched Friars. A stone, erected by his widow, is let into the

* The statute of 'Six Articlos,' published in 1539 by Henry VIII., decreed the acknowledgment of transul)stantiation, communion in one kind, rows of chastity, private masses, celibacy of the clergy, and auricular confessi n. Offenders were punishab?e as heretics. 
corner of the east-rall, on which the Latin inscription is still easily legible. He left two daughters and a son.

Turner's works are theological, medical, botanical, and general, of which a list is given in the 'Flora of Middlesex,' already mentioned. One example will serve to illustrate the curious titles of his controrersial works:- "The huntyng and fynding out of the Romyshe Foxe, which more than seuen yeares hath bene hyd among the bisshoppes of Englonde, after that the Kynges Hyghnes had commanded hym to be dryven owt of hys Realme.' Basyll, 1543. $12 \mathrm{mo.}$ Published under the pseudonym of Willn. Wraghton, and dedicated to King Henry VIII.

Turner's first botanical work, called 'Libellus de Re Herbaria noxus' (new pamphlet on Botany), was printed in London in 15:38. It was a quarto tract of twenty pages, in which are noticed the localities of several plants in his native county of Northumberland; and these are the earliest printed records of the kind in England. In 1518 he published 'The Names of Ilerbes in Grelie, Latin, Englishe, Duche, and Frenche, wyth the commune names that Herbaries and Apotecaries use.' London. The preface is dated from Sion House, the residence of the Lord Protector, to whom the book is dedicated.

His 'Herbal,' by which Turner is best known, appeared at different times. The first part, dedicated to the Duke of Somerset, was published in 1551: it is called ' $A$ New Herball, wherein are conteyned the names of Herbes in Greke, Latin, Englysh, Duch, French, and in the Potecaries and Herbaries Latin; with the properties, degrees, and naturall places of the same; gathered and made by Wylliam 'I'urner, Phisicion rnto the Duke of Somersettes Grace.' It is a folio book, containing ninety-four leares in all. 'The seconde parte of ruilliam Tumer's Herball, wherein are conteyned,' Sc., was published at Cologne in 1562; and the 
third part at the same place in 1566. The three partscollected together into one volume, with some additions and alterations-were published in 1568, dedicated to Queen Elizabeth. In this work upwards of three hundred species are given as natives of England.

\section{Anthony Aschalr.}

The Herbal of Anthony Ascham is thus mentioned by Pulteney:

"Anthony Ascham, a priest, and vicar of Burnishton, in Yorkshire, to which he was preferred by Edward VI., after a liberal education, which, it might have been expected, would have secured him from such delusion, gave himself up to the study of astrology, on which subject he published sereral tracts. He wrote also 'On the LeapYear ;' and the following: 'A Lyttel Herbal of the properties of Herbs; newly amended and corrected, with certain additions at the end of the boke; declaryng what herbs have influence of certain starres and constellations, whereby may be chosen the best and most lucky times and days of their ministration, which is daily appointed in the Almanack. Made and gathered in the year MI.D.L., xii. Feb., by Anthonye Ascham, Physician. Lond. 1550. 120."'

\section{Retnbert Dodoexs.}

Jolnsun, in his edition of Gerard's Herbal, gives the following account of the work of Dodonæus :-

"Rembertus Dodonceus, a Fhysician, born at Mechlin, in. Brabant, about this time, began to write of Plants. He first set forth an listory in Dutch, which by Clusius was turned into French, with some additions. An. 1560 .

* 'Historical and Biographical Sketches of the Progress of Botany in England, from its Origin to the Introduction of the Linnwan System.' By Richard Pulteney, MI.D., F.R.S. 1790. 
And this was translated out of French into English by Mr. Henry Lyte, and set forth with figures, Ain. Dom. 1578; and diver's times since printed, but without figures. In the yeare 1552 Dodonxus set forth in Latine his 'Frugum historia,' and, within a while after, his 'Florum purgantium et deleteriorum historia.' And afterwards he put them all together, his former and those his later Works, and diuided them into 30 books, and set them forth with 1305 . figures, in fol. Ann. 1583. This edition was also translated into English, which became the foundation of this present Worke, as I shall shew hereafter. It hath since been printed in Latine, with the addition of some few new figures; and of late in Dutch, Ann. 1618, with the addition of the same figures, and most of those in the Exoticlis of Clusius, and great store of other additions."

\section{Ranis Littue Dodeon.}

" A briefe Epitome of the new Herball, or History of Plants out of the most exquisite," \&c. The author of this curious little work, of which there is a copy in the British Museum, was, I suppose, the William Ramme, alluded to by Gerard in his chapter on the Thorn-apple:"The iuice of Thorne apples boiled with hogges grease to the forme of an vnguent or salve, cureth all inflammations whosoeuer, all maner of burnings or scaldings, as wel of fire, water, boiling lead, gunpowder, as that which comes by lightning, and that in a very short time, as myselfe haue found by my daily practise, to my great credite and profite. 'The first experience came from Colchester, where mistresse L'ubel, a marchants wife there, being most greeuously burned with lightning, and not finding ease or cure in any other thing, by this founde helpe when all hope was past, by the report of master William Ramme, publike notarie of the saide town was perfectly cured." 


\section{John Gerard.}

These additional notes about Gerard are chiefly taken from an interesting article in the 'Journal of Horticulture,' February 18th, 1875.

The date of Gerard's birth cannot be ascertained with certainty. There is no entry of his baptism in the Nantwich registers from 1539 to 1545 , the only early entries, and all subsequent ones, are lost down to the year 1572. It has, therefore, been derived from the Latin inscription round his portrait prefixed to his 'Herball,' which in English is"Portrait of John Gerard, of Cheshire, citizen and surgeon of London, in the 53 year of his age, 1598." He was born at Nantwich, and went to school in the same neighbourhood, as appears from his 'Herbal.' He says of Cardamine pratensis that it is "called at that Namptwich in Cheshire where I had my beginning, Ladie smockes," and of Pubus idrus, "I have found it among the bushes of a carsey neere vnto a village called Wisterson, where $I$ went to schoole, two miles from the Nantwitch in Cheshire."

Gerard's first publication was his 'Catalogue of Trees, Shrubs, and Plants, both Indigenous and Exotic, growing in the garden of John Gerard, citizen and surgeon of London.' It is dedicated to Lord Burleigh, and occupies eighteen small quarto pages in double columns. The plants are arranged alphabetically, from Abies to Zizyphus, and are 1039 in number. There is a second edition of this work.

Gerard was the first cultivator of the potato in England; and, in the portrait which appears in both editions of his 'Herball,' he is represented with a sprig of the plant in his hand. He was chairman of the company of Barber-Surgeons, which two occupations were conjoined, even among the early Greeks and Romans. The BarberChirurgeons were incorporated here in 1436, and their Hall 
was on the west side of Monkwell Street, in Farringdon Ward. These two occupations were separated by a statute, passed 1546, which forbade barber's performing any other surgical operation than dratring teeth; so that, though the company still existed, its occupation was gone. It is certain that Gerard never followed the profession of barber, but of "surgeon and herbarist." After the long period-over twenty years-during which he was gardener to Lord Burleigh, it seems he was employed by James I. and his queen; for among the public records are the following:- "Anne, queen of England, \&c., for the sum of five shillings, by way of fine paid by John Gerard, of London, surgeon and herbarist to the king, and for other considerations; but especially of his singular and approved art, skill, and ministrie in planting, nursing, and preserving of plants, pear-trees, flowers, and fruits of all kinds, do grant and let to him one garden plot.... containing about two acres, to be held by him (\&c.) from the feast of St. Michael next ensuing, for the term of the queen's life, and for twenty-one jears, paying annually a rent of fourpence, to be paid quarterly, and yielding for our own use at the proper seasons of the year a convenient quantity of herbes, flowers and fruits, growing in the said garden, by the art and industry of the said John Gerard, if they be lawfully demanded of him."

But little more is known about Gerard. That he travelled out of England is shown by a remark in his chapter on the "Firre, or Deale-tree," of which he says:"They are found likewise in Pruse, Pomerania, Liefeland, Russia, and especially in Norway; where I have seene the goodliest trees in the worlde of this linde, growing vpon the rockie and craggie mountaines, almost without any earth about them, or any other thing, sauing a little mosse about the rootes, which thrust themselues heere and there into the chinkes and cranies of the rockes, and therefore are easily 
cast downe with any extreme gale of winde." He frequently mentions different English counties which he seems to have visited; but it is somerwhat curious that we should know so little of such a well-known man; and it is no slight credit to his 'Herbal' that it alone should have preserved Gerard's name to us as a "household word." We know nothing of his private life, whether he was married or single, whether he was wealthy, or in fairly good circumstances, or poor, except by conjecture. Even the time of his death was set down incorrectly by Johnson, and has been repeated ever since. The writer of the article in the 'Journal of Horticulture,' which has been already mentioned, says:- "All who have written about him state that he died in 1607. As he lived and died in Holborn, it would have been easy to consult the registers of St. Andrew's Church, in that parish; but no one ever did until-within a few days of my writing this-I turned over the parchment leaves of those well-kept registers, and in them found this entry:- "Mr.John Gerrard, freeman of the Barber-Chirurgeons, buried the xviii. February, 1611." That would have been 1612, had the year then, as now, commenced in January.

Gerard was evidently a parishioner of consideration, for he is the only one in that and other years with the prefix of "Mr." All others have, at the most, merely their christian and surnames recorded, whilst too many have such a totally useless record, as "A poor man," or "A maid from John Smith's, buried this day."

\section{Thomas Johnson.*}

Johnson, as a botanist, is especially remarkable for introducing the useful plan of carefully examining the Floras of small districts, and next for his new and much enlarged edition of Gerard's 'Historie of Plants.' He published a

*. See 'Flora of Middlesex.' 
narrative, dated July 13 th, 1629, of an expedition in a company of ten to investigate the plants of Kent, which has been described as "A pleasantly written account of one of the herborising excursions, which for some years it had been the practice of the company to make at intervals. This is the first printed account of a botanical excursion in England." An appendix of three pages gives us the results of a similar journey to Hampstead Heath, on August 1st, 1629. In 1632 Johnson published a list of plants growing on Hampstead Heath and the neighbourhood, consisting of seven pages, six of which are occupied by a catalogue of names. "This catalogue may be considered as the first 'Flora' of a small district printed in England."

Johnson's edition of Gerard's 'Herbal' is dated, in his letter to the reader, "From my house on Snow-hill, Octob. 22, 1633. He tells us in his Appendix that he was "forced to perform this task within the compasse of a yeare," which, considering the extent of the work and the ability with which it is performed, shows him to have been an expeditious writer, and one who well understood his subject. Notwithstanding the many excellencies of Gerard's book and its great popularity, a new and improved edition was greatly wanted, by reason of the numerous errors in the original work. Johnson remarks of Gerard:- "His chiefe commendation is, that he out of a propense good will to the publique aduancement of this knowledge, endeauoured to performe therein more than he could well accomplish; which was partly through want of sufficient learning, as (besides that which he himselfe saith of himselfe in the chapter of Water Docke) may be gathered by the translating of diuers places out of the Aduersaria." .... The sentence to which Johnson alludes is creditable to Gerard, as showing his modesty, other instances of which are not wanting (see account of the Goose-tree, p. 46). It is as follows:- "Other 
distinctions and differences, with the temperature and euery other circumstaunce, I leave vnto the learned phisitions of our London colledge (who are very well able to search into this matter), as a thing far aboue my reach, being no graduate, but a countrie scholler, as the whole framing of this historie doth well declare: but I hope my good meaning will be well taken, considering I do my best, not doubting but some of greater learning will perfect that which I have begun according to my small skill, especially the ice being broken vnto him, and the woode rough hewed to his handes."

The additions made by Johnson to Gerard's 'Herbal' are so numerous that it is almost entitled to be considered a new book; and to treat it all as Gerard's work, as is done by Smith (in Eng. Flo.), who quotes "Gerard" always from this edition, is not correct. The additions of plants amount to 800 , and of figures 700 ; and the additional matter to and the corrections of the original are of great extent and importance. Another merit of this work of Johnson's is that he clearly points out where and to what extent he has altered the original. He adds an appendix of forty pages and thirty chapters with this proem:-

"An Appendix or Addition of certaine Plants omitted in the former History.

\section{"The Preface.}

"Hauing r'un through the history of plants gathered by Master Gerard, and much inlarged the same, both by the addition of many figures and histories of plants not formerly contained in it, and by the amending and increasing the history of sundry of those which before were therein treated of; I finde that I haue forgotten diuers which I intended to haue added in their fitting places: the occasion hereof hath been, my many businesses, the troublesomnesse, and aboue all, the great expectation and haste of the Worke, whereby 
I was forced to perform this task within the compasse of a yeare. Now being constant to my first resolution, I here haue, as time would giue me leaue, and my memorie serue, made a briefe collection and addition (though without method) of such as offered themselues to me; and without doubt there are sundry others which are as fitting to be added as those; and I should not haue bin wanting if time had permitted me to have entred into further consideration of them. In the meane time take in good part those that I have here presented to your view."

Johnson "seems to have been as good a soldier as a botanist, for he distinguished himself greatly in the war, and became lieutenant-colonel to Sir Marmaduke Rawdon. In 1642, the University of Oxford made him a Bachelor of Physic, and in the next year he proceeded to MI.D. He did not, however, live long to practice his profession as a physician, for on September 14th, 1644, during a skirmish with the rebels under Colonel Richard Norton, at the siege of Basing House, he received a shot in the shoulder, 'whereby contracting a feaver, he died a fortnight after.' He was much regretted, being, we are informed, 'no less eminent in the garrison for his valour and conduct as a soldier, than famous through the kingdom for his excellency as an herbalist snd physician."”

\section{John Parkinson.**}

John Parkinson was born in 1567, for the inscription on his portrait, published in 1629, states that he was then in his sixty-second year. The place of his birth is not known, but is supposed to have been somewhere in Nottinghamshire. The greater part of his life was spent in London, where he followed his profession of apothecary and herbalist, a profession which does not appear to have been very * See 'Journal of Horticulture,' June 24th, 1875. 
lucrative, and therefore (perhaps) was not much honoured. Nevertheless Parkinson spent a long life, evidently with satisfaction to himself and benefit to his countrymen. He was assiduous in the collection and cultivation of new plants, and tells us that he had spent nearly forty years in "travell," or, as we now spell it, "travail," to acquire a knowledge of plants; and, not satisfied with his own researches, he contributed to the expenses of one botanist to enable him to search some parts of Europe for new plants, but was justly displeased with him, for he, "going," as Parkinson says, "into Spaine, almost wholly on my charge, brought me little else for my money than seeds of Chiceling Peas." Yet he gave seeds to others; so that "I beate the bushe, and another catcheth and eateth the bird." Then, also, as now and at all times, there were well-to-do patrons of botany, merchants, and others who were of assistance; and Parkinson mentions some of those who helped his collection:-

"Mr. Nicholas Lete, a worthy merchant, and a lover of all faire flowers."

"Mr. John de Franqueville imparted to me many good things."

"Mr. John Gordier (Goodyer), a great lover and curious searcher of plants, who hath found in our country many plants not imagined to grow in our land. I wish there were many more of his minde, that not hindering their affaires at spaire times would be industrious to search out and know what the ground bringeth forth where their occasions are to be." (See Goodyera.)

Altogether, Parkinson made a fine collection of flowers, fruits, and herbs. Thus he says of roses :- "I have of roses to furnish this garden thirty sorts at the least, every one notably different from the other both in form, colour, and smell;" while of tulips he had one hundred varieties; and 
so on throughout. He introduced our garden rhubarb, which he makes mention of in these words:- "I have a kinde of round leafed Dock growing in my Garden, which was sent me from beyond Sea by a worthy Gentleman, Mr. Dr. Matth. Lister, one of the King's Physitians, with this title, Raponticum rerum, and first grew with me, before it was ever seen or known elsewhere in England, w... by proof I haue found to be so like vnto the true Rubarbe, or the Rha of Pontus, both for forme and colour, that I daresay it is the very true Rubarbe, our climate only making it lesse strong in working, lesse heauy, and lesse bitter in taste."'Paradisus.'

His two works-one on gardening, and the other on general botany-have already been mentioned (p. 50). The title of the first work in full is-

\section{'PARADISI IN SOLE,}

Paradisus Terrestris :*

or,

A Garden of all sorts of pleasant flowers which our English ayre will permitt to be noursed $\mathrm{vp}$ : with a Kitchen garden of all manner of herbes, rootes, and fruites, for meate or sause vsed with vs, and an Orchard of all sorte of fruit bearing Trees and shrubbes fit for our Land, together with the right orderinge, planting, and preseruing of them, and their vses and vertues. Collected by John Parkinson, Apothecary of London, 1629.' It was dedicated to the queen (Henrietta Maria).

A second edition of the 'Paradisus' appeared in 1656, six years after the death of its author.

Parkinson's other work was entitled, 'Theatrum Botanicum: the Theater of Plants, or an Herball of a large extent.' The title-page states more at length what the work contains :- "Collected by the many yeares travaile, industry,

* The translation is 'Park-in-sun's Terrestrial Paradise.' 
and experience in this subject by John Parkinson, Apothecary of London, and the King's Herbarist. Published by the Kings Majestyes especiall priviledge." 1640. This work was dedicated to the king.

Parkinson died in 1650 , and the register of burials of St. Martin-in-the-Fields contains this entry:- "1650, Aug. 6, John Parkinson sepultus." Guided by the inscription on his portrait we thus learn that his death occurred in his eighty-third year.

We may say of Parkinson's 'Paradisus' that it is not only the first work we have of its kind, but that it shows so much acquaintance with the subject, and is written in so pleasant a style, that it still remains a very excellent gardening book.

\section{John Evelyn.}

John Evelyn was born at Wotton, in Surrey, the seat of his father, Richard Evelyn, Esq., October 31st, 1620. He was descended from a very ancient and honourable Shropshire family, which settled at Wotton in the reign of Queen Elizabeth. His first instruction was received in the free-school at Lewes, from which he was removed in 1637 , and was then placed at Baliol College, Oxford, where he remained three years studying diligently. After this he removed to the Middle Temple, London, to acquire some knowledge of law. In 1644 he left England to travel on the continent, where he remained some years, returning about 1651. In 1647 he was in Paris, and, being recommended to Sir Richard Browne, the king's minister there, he became acquainted with his only daughter Mary, whom he shortly afterwards married, and by whom he became possessed of Sayes-Court, near Deptford. Here he took up his residence, and lived a very retired life, the violence and confusion of the times being rery repugnant to his studious and gentle temper. 
He had it even in mind, and suggested it to his friend Boyle, to establish a retreat, where the lovers of virtue and science might shelter themselves from the accidents of the times. In 1699 he succeeded to the family estates, and removed to Wotton, where he passed the remainder of his life.

"Evelyn lived through the troubled times of Charles I., Cromwell, Charles II., James II., and William ; and without surrendering any principle, or condescending to any flattery, he was preserved from persecution by the respect universally accorded to his character. He lived in intimacy with men of all persuasions; and few foreigners, distinguished for learning or arts, left England without visiting him."**

Evelyn died in the eighty-sixth year of his age, 27th February, 1705-6, and was buried at Wotton. His tomb, by his desire, bears this inscription:- "Living in an age of extraordinary events and revolutions, he had learned from thence this truth, which he desired might be thus communicated to posterity: That all is vanity which is not honest; and that there is no solid wisdom but in real piety."

Evelyn's writings were very numerous and on many subjects, which, as not concerning this work, I do not specify. The most important and best known is his 'Silva ; or, a Discourse of Forest-trees, and the propagation of Timber in his Majesty's dominions.' This work was written, at the request of the Royal Society, "upon occasion," as it is stated on the title-page, "of certain Queries propounded to that Illustrious Assembly by the Hon. the Principal Officers and Commissioners of the Navy." It was delivered, 15th October, 1662, and published by order of the Royal Society. It has since "undergone several editions: a second in 1669 ; a third in $16 ; \% 9$, with great additions and improvements; a fourth in 1705 , still considerably augmented;

* 'Imperial Dictionary of Universal Biography.' 
and a fifth in 1729, with all the lesser pieces of our Author relating to Agriculture and Gardening annexed, as they were in the fourth. But these two last editions are extremely incorrect." * Since then three editions, with copious notes, have been published by Dr. Hunter, of York; the last in 1801.

Evelyn's 'Silva' is worthy of all the encomiums that have been bestowed on it, and there can be no doubt that it has done much to promote a judicious culture of forest trees. In his Epistle Dedicatory to "The King's most sacred Majesty, Charles the second," the author says:- "I need not acquaint your Majesty how many millions of timber-trees, besides infinite others, have been propagated and planted throughout your vast dominions, at the instigation, and by the sole direction of this work; because your gracious Majesty has been pleased to own it publickly for my encouragement, who, in all that I here pretend to say, deliver only those precepts which your Majesty has put into practice; as having like another Cyrus, by your own royal example, exceeded all your predecessors in the plantations you have made, beyond, I dare assert it, all the monarchs of this nation since the conquest of it."

P. 69. Buffonia tenulfolia. - It is pretty well established that Smith was wrong as to the intention of Linneus in the application of the name.

P. 72. Vrola Lutea. - A blue variety of this plant is not unfrequent: it is figured in the new edition of 'Sowerby's Botany,' by Dr. Syme.

P. 77. Exglish Botaxy. - There can be little doubt that this work is correctly called "Sowerby's" 'English Botany,' for it was chiefly remarkable for the excellence of its plates, with which it originated; and Smith was employed to write

* Evelyn's 'Silva,' by A. Hunter, M.D., F.T.S.L. and E., srd ed. 
the descriptions at a guinea for each article. Yet he was rery sore about the book being called 'Sowerby's Botany', and thereby gave an illustration of the petulance of his temper. (See 'Journal of Botany,' 1872, p. 374.)

P. 80. Lindeny's Herbariun.-This valuable collection is now at Cambridge, excepting the Orchidacer, which are at Kew. Two of Lindley's most important works should be noticed, riz. 'Genera and Species of Orchids,' and 'Folia Orchidacea.'

P. 81.-The 'Miscellaneous Botanical Worlss of Robert Brown,' in 2 vols., with a vol. of plates, was issued by the Ray Society in 1866. 


\section{INDEX.}

Abbreviations 9i

Abenguefit 24

Absinthium 106

Abu-al-Teifuri 20

Abul Faradsch Dschordschis 28

Acanthium 148

Accentuation 9?

Acer 98

Aceras 98

Acetosella 149, 160

Acinos 111

Aconitum 98

Acorus 99

Actæa 99

Actinocarpus 99

Adanson 117

Adder's-tongue 148

Adiantum 99, 174

Adiantum-nigrum 107

Adonis 99

Adoxa 99

Agopodium 99

Asculapius 2

Æthusa 100

Agraphis 100

Agrimonia 100

Agrostemma 100

Agrostis 100

Ahmed Ben Ibrahim 18

Aira 100

Ajuga 100

Alchemilla 101

Alchindi 19

Alexanders 169

Alfred the Great 19

Alisma 101

Alizarin 160

Alliaria 101

Allium 101

Allosorus 101

Allseed 153, $15 \%$

Alnus 102

Alopecurus 102

Alpini 42

Alsinastrum 102

Alsine 102
Althæa 102

Alyssum 102

Amara-dulcis 169

Amarantus 102

Amarella 131

Ammophila 102

Amomum 168

Ampeloprasum 101

Anacharis 102

Anagallis 102

Anchusa 103

Andromeda 10 :

Androsæmum 135

Anemone 103

Angelica 103

Anne of Cleres 31

Anserina 155

Antennaria 103

Antirrhinum 104

Anthemis 103

Anthriscus 104, $17 \pm$

Anthoxanthum 103

Anthyllis 104

Apargia 104

Aparine 130

Apera 181

Aphaca 138

Apium 104

Apuleius 10

Aquifolium 135

Aquilegia $10 \pm$

Arab inventions 29

Arabic names 16

Arabis 104, 18 ?

Arbuscula 161

Arbutus 104

Arctium 105, 130

Aretostaphylos 105

Arenaria 105

Argemone 150

Argentina 155

Argonautic expelition 2

Aria 157

Aristolochia 105

Aristotle 4

Armeria 105, 122, $16 \%$

Armoracia 105
Arnoseris 105

Arrenatherum 105

Artemisia 105

Arthrolobium 106

Arum 106

Asarum 106

Ascham, Anthony 38,215

Ash 129

Asparagus 106

Asperugo 106

Asperula 106

Aspidium 106

Asplenium 106, 175

Aster 107

Astragalus 107

Astrantia 107

Astrology 51

Athamanticum 144

Athyrium 107

Atriplex 107

Atropa 107

Auricula 128, 177

Australia, Government

Expedition to 82

Avellana 119

Avena 108

Avens 123

Averroes 25

Avicenna 23

Azalea 108

Ballota 108

Banks, Sir Joseph 76, 82

Barbarea 108

Barbarus 4

Barilla 161

Barnakle-tree 46

Barren Strawberry 155

Bartsia 108

Bauhin, Caspar 5, 49

Bauhin, John 49

Beak-rush 159

Bear-berry 105

Beccabunga 178

Beech 128

Beech-fern $15 t$

Beet 108 
Belladonna 108

Bellis 108

Berberis I08

Beta 108

Betonica 108

Betula 109

Betulus 11:3

Bidens 109

Bindweed 119

Birch 109

Birdlime-wort 141

Bistorta 154

Bitter-sweet 169

Black Aller 159

Black Bryony 172

Blattaria 177

Blechnum 109

Blitum 102

Blue-bottle $11 t$

Blysmus 109

Boerhaave 57

Bonus Henricus 116

Borago 109

Borkhausia 110

Botany and Medicine 79

Botrychium 110

Botrys 173

Box 110

Brachypodium 110

Bramble 160

Brassica 110

Briza 110

Bromus 110

Broom 130, 169

Brown, Robert 81, 228

Brunella 156, 181

Brunfels 34,36

Bruseus 160

Bryonia 110

Buckthorn 159

Buffon 8, 63

Buffonia 69, 227

Bulbocastanum 113

Bunium 110

Bupleurum 110

Bursa-pastoris 112

Butomus 110

Butterwort 152

Buxus 110

Cæsalpinus 40

Caille-lait 130

Cakile 110

Calamagrostis 110

Calamintha 111

Calamus 99

Calceolus 121

Calcitrapa 114
Calf's-snout 104

Callitriche 111

Calluna 111

Caltha 111

Calystegia 111

Camelina 112

Camerarius 41

Campanula 112

Cannabis 112

Capillus-Veneris 99

Caprea 161

Capsella 112

Caraway 113

Cardamine 112

Cardiaca 138

Carduus 112

Carex 113

Carlina 113

Carota 122

Carpinus 118

Carui 113

Carum 113

Caryophyllata 12:3

Caryophyllus 122

Castanea 114

Catabrosa 114

Catch fly 142, 16 \%

Cato 5

Caucalis 114

Celery $10 \pm$

Centaurea 114

Centaureum 126

Centranthus 114

Centum morbia 142

Centunculus 115

Cephalanthera 115

Cerastium 115

Cerasus 156

Ceratophyllum 115

Cerefolium $10 \pm$

Ceterach 115, 165

Chærophyllum 115

Chamædrys 173

Chamæpytis 101

Chamagrostis 115

Chamomilla 143

Charles II. 56

Cheese-rennet 1:30

Cheiranthus 115

Cheiri 115

Chelidonium 116

Chenopodium 116

Cherleria 116

Cherry tree 150

Cheryil 164, 174

Chlora 116

Chrysanthemum 117

Chrysosplenium $11 \%$
Cicendia 117

Cichorium 117

Cicuta 117

Circra 117

Cladium 118

Claytonia 118

Clematis 118

Clinopodium 111

Clusius 48

Cnicus 118

Cochlearia 118

Cock's-comb 159

Colchicum 119

Colt's-foot 176

Columbaria $16 \pm$

Columella 6

Columna 41

Comarum 119

Conium 119

Consolida 122

Convallaria 119

Convolvulus 119, $15 \pm$

Conyza 136

Cool tankard 156

Corallorhiza 119

Cordus 34,36

Coriandrum 119

Cornus 119

Coronopus 152, 166

Corrigiola 119

Corydalis 119

Corylus 119

Cotoneaster 119

Cotnla 103

Cotyledon 119

Cracca 179

Crambe 119

Crane's-bill 131

Cratægus 120

Crepis 120

Crista-galli 159

Crithmum 120

Crocus 120

Crosswort 130

Crowfoots 158

Cruciata 130

Crus-galli 150

Cryptogramma 120

Cucubalus 120

Culpeper 51

Cuseuta 120

Cuvier 8

Cyanus 114

Cyclamen 120

Cymbalaria 139

Cynanchica 106

Cynapium 100

Cynodon 120 
Cynoglossum 121

Cynosurus 121

Cyperissias 127

Cyperus 121

Cypripedium 121

Cystopteris 121

Cytisus 181

Dabeocia 181

Dactylis 121

Dactylon 120

Dalechamp 38

Damasonium 99

Dandelion 172

Danewort 163

Daphne 121

Darnel 140

Datura 121

Daucus 122

Delphinium 122

Dens-leonis 172

Deslongchamps 140

Dianthus 122

Digitalis 123

Digitaria 123

Digraphis 123

Dillenius 59

Dioscorides 4

Diotis 123

Diplotaxis 123

Dipsacus 123

Eastern botany 1

Ebn AbuOseibia 15,26, 27

Ebn Abu Zaher 18

Ebn Al Beitar 26

Ebn Roschd 25

Ebn Sina 23

Ebn Wafid 24

Ebulus 163

Echinochloa 124

Echinophora 124

Echium 124

Elatine 124

Elder 162

Eleocharis 124

Elodea 124

Eltham garden $60,16 \tau$

Elymus 125

Empetrum 125

Endymion 182

English Botany, Sower. by's $77,22 \pi$

English Physician, the 51

Epilinum 120

Epilobium 125

Epimedium 125

Epipactis 125
Epipogium 125

Epithymum 120

Equisetum 125

Eranthis 125

Erica 125

Erigeron 125

Eriocaulon 126

Eriophorum 126

Erodium 120

Erophila 182

Eryngium 126

Erysimum 126

Erythræa 126

Esparto 169

Esula 127

Euonymus 126

Eupatorium 100, 126

Euphorbia 126

Euphragia 182

Euphrasia 127

Evelyn 56, 225

Eyebright 128

Fagopyrum 154, 182

Fagus 128

Farfara 176

Fedia 128

Festuca 128

Ficaria 157

Filago 128

Filipendula 170

Filix-fœmina 107

Filix-mas 106

Film ferns 135

Fitz Herbert, Judge 3 \%

Flammula 157

Flinders, Captain 82

Flora, first local 50, 220

Flos - Constantinopolitanus 151

Flos-cuculi 141

Fœniculum 128

Fool's Orchis 149

Fool's Parsley 100

Forskal 121

Fox-glove 123

Fragaria 128

Fragariastrum 155

Frangula 159

Frankenia 128

Fraxinus 129

Fritillaria 129

Frog-bit 135

Fuchs 36

Fumaria 129

Fumus-terræ 129

Gage, Sir Thos. 129
Gragea 129

Galanthus 129

Gale 145

Galen 11

Galeobdolon 129

Galeopsis 129

Galinsoga 182

Galium 130

Gall-bush 145

Garlic 101

Garlic Germander 173

Garlic Sage 173

Gastridium 130

Genista 130

Genserich 155

Gentiana 130

Georgies 5

Geranium 131

Gerard 42, 217

Germander 173

Gesner $3 \pm, 36$

Geum 131

Githago 100

Gladiolus 131

Glaucium 131

Glaux 131

Glyceria 131

Gmelin 96, 125

Gnaphalium 131

Goatweed 99

Golden Ass, the 11

Golden-rod 169

Good Henry 116

Goodyer 131, 223

Goodyera 131

Gooseberry 159

Goose-foot 116

Goose-grass 155

Goose tree 46

Gorse 130, 176

Goutweed 99

Grass of Parnassus 150

Grassette 152

Gray 32, 43

Greek, pronunciation of 94

Greek Valerian 153

Greeks, early 2

Green weed, Dyers' 130

Gregorius Abul Pharadsh 15

Gregorius Bar Hebräus 28

Grete Herbal 32, 212

Gronovius 118, 140

Grossularia 159

Gymnadenia 131

Gymnogramma 131 
Habenaria 131

Haller 58

Haloscias 182

Hard fern 109

Hare's-tail grass 137

Harun 19

Hazel 119

Hedera 132

Helenium 136

Heleocharis 132

Helianthemum 132

Helioscopia 127

Helix 132, 162

Helleborus 132

Helminthia 132

Helosciadium 132

Hemp 112

Hemp Agrimony 126

Heracleum 132

Herb Bennet 123

Herb Gerard 99

Herb Paris 150

Herculaneum 9

Herminium 133

Herniaria 133

Hesperis 133

Hieracium 133

Hierochloe 133

Hippocrates 2

Hippocrepis 133

Hippophaë 133

Hippuris $13 \pm$

Hirculus $16 \pm$

History of the world 8

Holcus 134

Holland, Philemon 9

Holly fern 106

Holoschœu 136,165

Holostea 170

Holosteum 134

Honckeny, G. A. 134

Honckenya 134

Honein 19

Hop 134

Hornbeam 113

Hotton, Pierre 134

Hottonia 134

Humulus 131

Hutchins, Miss 134

Hutchinsia 134

Hyacinth 134

Hydrocharis 135

Hydrocotyle 135

Hydrolapatham 160

Hydropiper 124, 154

Hymenophyllum 135

Hyoscyamus 135

Hypochæris 135
Hypopitys 145

Iberis 135

Ilex 135

Illecebrum 135

Impatiens 136

Intybus 117

Inula 136

Irio 168

Iris 136

Isatis 136

Isnard, Antoine d' 136

Isnardia 136

Isoëtes 136

Isolepis $136^{\circ}$

Jacea 114

Jacobæa 166

Jacubite Christians 22

Jacob's ladder 153

St. James' wort 166

Jasione 136

Johannitius 19

Johnson, Thomas 50,219

Josephus 1

Juneus 137

Juniperus 137

Kali 162

Kindi, al- 19

Kitchen gardens orchards 31

Knapp, J. L. 137

Knappia 137

Knaut, Christian 137

Knautia 137

Knot-grass 153

Kobres, MI, de 137

Kobresia 137

Koch, W. D. J. 151

Koeler, G. L. 137

Koeleria 137

Koniga 137

\section{Lactuca 137}

Ladanum 129

Lady-fern 107

Lady's slipper 121

Lagurus 137

Lamium 137

Lanceolata 153

Lantana 178

Lappa 105

Lapsana 137

Lastrea 137

Lathræa 138

Lathyris 127

Lathyrus 138
Latin writers 5

Laureola 121

Lavater, the Brothers 138

Lavatera 138

Leers, J. D. 138

Leersia 138

Lelamer 30

Lemna 138

Leontodon 138

Leonurus 138

Leopard's bane 123

Lepidium 139

Lepturus 139

Leucanthemum 117

Leucojum 139

Ligusticum 139

Ligustrum, 139

Lilium 139

Limnanthemum 139

Limonium 170

Limosella 139

Linacre 30

Linaria 139

Lindley, John 66, 77, s0, 228

Iing 111

Lingua 158, 165

Linnæa 140

Linnean canons 64

Linveus 60

and Linosyris 140

Linum 140

Liparis 140

Iister, Martin 140

Listera 140

Lithospermum 140

Littorella 140

Lloyd, Edward 140

Lloydia 140

Lobel 40

Lobelia 140

Loiseleurea 140

Lolium 110

Lomaria 140

Lonchitis 106

Lonicer 38

Lonicera 140

Loo:e-strife 142

Lotus 141

Lucullus 156

Ludwig, C. G. 141

Ludwigia 141

Lumpers 88

Lunaria 110

Lupulus 134

Luteola 159

Lychnis 141

Lychnitis 177 
Lycopodium 142, 166

Lycopsis 142

Lycopus 142

Lysimachia 142

Lyte, Henry 40

Lythrum 142

Macer 6

Macer's Herbal 30

Madder 160

Mæcenas 5

Magnol 54

Maianthenum 142

Maiden-hair fern 99

Maiden-hair spleenwort 106

Malachium 143

Malaxis 143

Male fern 106

Malik, al- 26

Malus 157

Malva 143

Mamum, al- 18

Mansur, al- 21

Mansur Ben Abul Fadhl Ben Ali 26

Marianus 113

Mariscus 118, 165

Marrubium 143

Marsh mallow 102

Masterwort 151

Matricaria 143

Matthiola 143

Matthiolus 4, 37

May flower 141

Meadow-sweet 170

Meconopsis 143

Medicago 143

Medicine and Botany 79

Melampyrum 143

Meleagris 129

Melica 143

Melilotus 143

Melissa 144

Melissophyllum 144

Melittis 144

Mentha 144

Menyanthes 144

Menzies, A. 144

Menziesia 144

Mercurialis 144

Mertens, F. C. 144

Mertensia 144

Mespilus 144

Mesue the elder 19

Mesue the younger 22

Meum 144

Mezereum 121
Milium 145

Millefolium 98

Millegrana 157

Mimulus 145

Misenum 9

Mistletoe 180

Mœnch, Conrad 145

Mœnchia 145

Mohammedan authors 20

Molina, J. J. 145

Molinia 145

Mollugo 130

Moneses 145

Money-wort 142

Monorchis 133

Monotropa 145

Monti, Guiseppe 145

Montia 145

Morio 149

Morsus-ranæ 135

Motasim, al- 19

Motewekkil, al- 19, 20

Mountain fern 106

Mulgedium 145

Mullein 177

Muscari 145

Myosotis $\mathbf{1 4 5}$

Myosurus 145

Myrica 145

Myriophyllum 146

Myrrhis 146

Myrsinites 162

Myrtillus 177

Naias 146

Names:-

barbarous 67,68

character, from cific 71

classes, of 70

colour of flowers, from 72

countries, from 71

fanciful 69

four quarters of the globe, from the 71

long 73

people, from names of 73

places, from 71

sarcastic 69

substantive or generic $6 \pm$

subtantive, old used as specific 89

trivial 71

unmeaning 67

Napellus 98
Napus 110

Narcissus 146

Nardus 146

Narthecium 146

Nasturtium 146

Nâthali, al- 23

Natural system 73

Navel-wort 119, 139

Neotinea 146

Nepeta 111, 147

Nephrodium 147

Nicander 179

Nicol 15

Nidus-avis 140

Nissole, M. G. 138

Nissolia 138

Noli-me-tangere 136

Nuh Ben Mansur 23

Nummularia 142

Nuphar 147

Nymphæa 147

Oak fern 154

Obier 179

Obione 147

Odontites 108

Eil de bonc 164

Enanthe 147

Enothera 148

Olusatrum 169

Onobrychis 148

Ononis 148

Onopordum 148

Ophioglossum 148

Ophrys 148

Ople tree 179

spe- Opulus 179

Orchis 149

Oreopteris 106

Origanum 149

Ornithogalum 149

Ornithopus 149

Orobanche 149

Orobus 179

Orontium 104

Osiris 10

Osmunda 149

Ostruthium 151

Otites 167

Our Lady 121

Ovid 6

Oriler 159

Oxalis 149

Oxyacantha 120

Oxyeoceos 149, 177

Oxyria 149

Oxytropis 148 


\section{Padus 156}

Pron 149

Pæonia 149

Panax coloni 44

Panic grass 125

Panicum 150

Paralias 127

Pardalianches 123

Parietaria 150

Paris 150

Parkinson, John 50, 222

Parnassia 150

Parthenium 143

Papaver 150

Pastinaca 150

Paulus 12

Pear tree 157

Pecten 104

Pedicularis 150

Pennywort 139

Peplis 127, 150

Peplus 127

Pera-pastoris 112

Periclymenum 140

Periwinkle 179

Persicaria 154

Persil noir 169

Petasites 151

Petroselinum 151

Peucedanum 151

Phalaris 151

Phegopteris 154

Phellandrium 147

Phleum 151

Phragmites 152

Phyllodoce 152

Physic gardens 31

Physospermum 152

Phyteuma 152

Picris 152

Pilosella 133

Pilularia 152

Pimpinella 152

Pinguicula 152

Pinus 152

Plantago 101, 152

Plautus 5

Pliny 7

Plumier 55.

Plum tree 156

Pneumonanthe 131

Poa 153

Pocock 15

Podagraria 99

Polemon 153

Polemonium 153

Polycarpon 153

Polygala 153
Polygonatum 153

Polygonum 153

Polypodium 154

Polypogon 154

Polystichum $15 \pm$

Pompeii 9

Poor man's reather glass 103

Populus 154

Potamogeton 154

Potentilla 155

Poterium 156

Priest, Dr. 43

Primula 156

Pronunciation of names 91

Prosper Alpinus 42

Prunella 156

Prunus 156

Psamma 157

Pseud-acorus 136

Pseudo-cyperus 113

Pseudo-narcissus 146

Pseudo-platanus 98

Ptarmica 98

Pteris 157

Pudentilla 10

Pulegium 144

Pulicaria 182

Pulmonaria 157

Pulsatilla 103

Pyrola 157

Pyrus 157

Quercus 157

Radiola 157

Rampion 112

Ram's Little Dodeon 40, Selaginella 166 216

Ranunculus 157

Rapa 110

Raphanistrum 158

Raphanus 1.58

Rapunculus 112

Ray, John 52

Razi, al- 20

Regina prati 170

Reiske 15

Reseda 158

Rhæas 150

Rhamnus 159

Rhinanthus 159

Rhodia radix 166

Rhynchospora 159

Ribes 159

Rivinus 55

Scirpus 165

\section{Sage 162}

Sagina 160

Sagittaria 161

Salad burnet 150

Salicaria 142

Salicornia 161

Salix 161

Salsola 162

Salvia 162

Sambucus 162

Samolus 163

Sanctuary 126

Sanguisorba 156, 163

Sanicula 163.

Saponaria 163

Sarsaparilla 168

Saussure, H. B. de 164

Saussurea 164

Scabiosa 114, 164

Scale fern 115

Scandix $16 \pm$

Scheuchzer, the

Brothers 69, 164

Scheuchzeria 164

Schœnoprasum 101

Schœnus 164

Scilla 165

Scleranthus 165

Sclerochloa 165

Scolopendrium 165

Scordium 173

Scorodonia 165, 173

Scorodoprasum 101

Scrophularia 165

Sea lavender 170

Sea onion 165

Sedum 165

Selago 142

Sempervivum 166

Senebier, J. 166

Senebiera 166

Senecio 166

Septfoil 155

Septifolium 155

Serapion the elder 22

Serpyllum 174 the younger $2 t$

Serratula 166

Seseli 166

Sesler, L. 166

Sesleria 166

Setaria 166

Shakespeare 38

Shepherd's purse 112

Sherards, the 60,166,167

Sherardia 166 
Sibbald, R. 167

Sibbaldia 167

Sibthorp, Dr. H. 16 i

Sibthorpia 167

Silaus 167

Silene 167

Silva, Evelyn's 56, 226

Silver weed 155

Silybum 167

Simethis 168

Simples 25

Sinapis 168

Sison 168

Sisymbrium 168

Sisyrinchinm 168

Sium 168

Smilacina 168

Smilax 168

Smith, Sir J. E. 68, 69, 75,227

Smyrnium 169

Sneezewort 98

Solanum 169

Soldanella 111

Solidago 169

Solomon 1

Sonchus 169

Sophia chirurgorum 168

Sow bread 139

Sowerby's English Botany 77, 227

Sparganium 169

Spartina 169

Specularia 170

Spergula 170

Spergularia 170

Sphondylium 133

Spicant 109

Spica-venti 100

Spiræa 170

Spiranthes 170

Splitters 88

Spoon-wort 118

Spurges 127

Squinancy-wort 100

Squirting cucumber 136

Stachys 170

Statice 170

Stellaria 170

Stramomium 122

Stratiotes 170

Strawberry 128

Strawberry tree $10 \pm$

Strigil 8

Strumarium 180

Struthion 151

Suæda 171

Subularia 171
Succisa 164

Symphytum 171

Tamarix 171

Tamus 172

Tanacetum 172

Taraxacum 138, 172

Tatula 122

Taxus 172

Teesdale, R. 172

Teesdalia 172

Telephium 166

Telmateia 125

Temperature of plants 33

Terminations of $\mathrm{L}$. adjectives 90

Tetrahit 130

Teucrium 173

Thalictrum 173

Thapsus 177

Thelypteris 106

Theophrastus 3

Thesium 173

Thlaspi 173

Thorn-apple 122

Thrift 105

Thrincia 173

Throat-wort 112

Thymus 173

Tilia 174

Tillæa 174

Tilli, M. A. 174

Toad-flax 139

Tofield 174

Tofieldia 174

Tordylium 174

Torilis 174

Tormentilla 155

Tournefort 55

Trachelium 112

Tragapogon 174

Tragus 39

Trichomanes 107, 174

Trichonema 175

Trientalis 175

Trifolium 175

Triglochin 175

Trigonella 175

Trinia 175

Trinius, K. B. von 175

Triodia 175

Tripolium 107

Trisetum 175

Triticum 175

Trollius 175

Trollflower 175

Tulipa 175

Turner, William 37, 212
Turrita 104

Turritis 176

Tussilago 176

Typha 176

Ulex 176

Ulmaria 170

Ulmus 176

Unedo 104

Uniformity, act of 53

Urtica 176

Utricularia 176

Uva-crispa 159

Uva-ursi 105

Vaccinium 177

Valerian, Greek 153

Valerian, Spur 114

Valeriana $17 \%$

Valerianella 177

Varieties 87

Varro 5

Venus' comb 164

Verbascum 177

Verbena 178

Veronica 178

Vesuvius 9

Viburnum 178

Vicia 179

Villarsia 179

Vinca 179

Viola 72, 179, 227

Viper's Bugloss 124

Virgil 5

Virgin Mary 121

Viscaria 141

Viscum 180

Vitalba 118

Vitis-idæa 177

Wahlenberg, G. 180

Wahlenbergia 180

Wallflower 115

Wall rue 107

Water dock 160

Water milfoil 171

Water soldier 170

Wayfaring tree 178

Wheat 175

Wild thyme 174

Willow herb 142

Willow tree 161

Winter green 170

Wolff, J. F. 180

Wolffia 180

Wood dog, for biting of 
INDEX.

Woods, J. 180

Woodsia 180

Woundwort, clown's 44

Würstenfeld 15
Xanthium 180

Yah ya Ben Mâseweih 19 Zannichellia 180

Yah ya Ebn Serapion 22 Zostera 181

E. NEWMAN, PRINTER, 32, BOTOIPH LANE, EASTCHEAP, E.C. 
QK11.A35

Alcock, Randal Hibb/Botanical names for

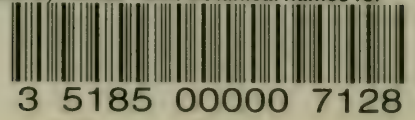






